\title{
Fingerprinting of Quartzitic Outcrops at Oldupai Gorge, Tanzania
}

María Soto a , Julien Favreau a, Kathryn Campeau b, c, Tristan Carter c, d, Matthew Abtosway a , Pastory M. Bushozi e , Siobhán Clarke ${ }^{\text {a }}$, Paul R. Durkin ${ }^{\mathrm{f}}$, Stephen M. Hubbard ${ }^{\mathrm{g}}$, Jamie Inwood ${ }^{\mathrm{a}}$, Makarius Itambu ${ }^{\text {a, e }}$, Samson Koromo ${ }^{\text {h }}$, Fergus Larter a, Patrick Lee a, b, Aloyce Mwambwiga ${ }^{\text {a, i }}$, Rajeev Nair ${ }^{\text {g, Lucas Olesilau }}{ }^{\text {h, Robert Patalano }}{ }^{\text {a, Laura Tucker a }}{ }^{\text {, Julio Mercader a }}$

a Department of Anthropology and Archaeology, University of Calgary, Calgary, AB, T2N 1N4, Canada.

${ }^{\mathrm{b}}$ Department of Anthropology, University of Toronto, Toronto, ON, M5S 2S2, Canada.

${ }^{\mathrm{c}}$ McMaster Archaeological XRF Lab, McMaster University, Hamilton, ON, L8S 4L9, Canada.

${ }^{\mathrm{d}}$ Department of Anthropology, McMaster University, Hamilton, ON, L8S 4L9, Canada.

e Department of Archaeology and Heritage Studies, University of Dar es Salaam, Dar es Salaam, United Republic of Tanzania.

${ }^{\mathrm{f}}$ Department of Geological Sciences, University of Manitoba, Winnipeg, MB, R3T 2N2, Canada. g Department of Geoscience, University of Calgary, Calgary, AB, T2N 1N4, Canada.

${ }^{\mathrm{h}}$ United Republic of Tanzania.

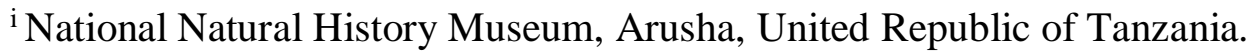

Corresponding authors: María Soto (maria.sotoquesada@ucalgary.ca); Julio Mercader (mercader@ucalgary,ca) 


\title{
Highlights
}

- Quartz-rich raw materials were extensively exploited in the African Early Stone Age.

- Few studies have characterized quartzitic outcrops as primary source areas.

- Macroscopic, petrographic, and EDXRF data used to fingerprint quartzitic outcrops at Oldupai.

- Baseline to interpret stone provenance and hominin palaeoecological behavior.

\begin{abstract}
The African Early Stone Age record, including that of Oldupai Gorge, reveals widespread evidence for hominin exploitation of quartzose lithic raw materials such as quartzite. However, few studies have sought to characterize these rock types grounded on the assumption that they are not amenable for provenance studies. Through the use of macroscopic, petrographic, and EDXRF analysis, we characterize source material from five quartzitic outcrops belonging to the Mozambique Belt adjacent to Oldupai Gorge. Our results show that certain macroscopic varieties strictly occur at some outcrops while petrographic analyses - which will be strengthened by a greater sample size - reveal that accessory minerals may be outcrop-specific. Statistical analyses of the geochemical data through linear correlations, Kruskal-Wallis tests, PCA, and DFA show that there are inter- and intra-outcrop differences, and elemental concentrations specific of certain outcrops. This multi-scalar approach provides a reproducible classificatory framework for additional characterization studies and archaeological testing at Oldupai to shed light on hominin palaeoenvironmental exploitation and palaeoecological behavior.
\end{abstract}

\section{Keywords}

Petrography; EDXRF; Quartzite; Sourcing; Oldupai Gorge. 


\section{Introduction}

Lithic raw material studies are generally based on survey programs intended to establish geological reference collections, which are characterized using destructive and non-destructive macroscopic, mineralogical, and geochemical techniques (Andrefsky, 2005; Calogero, 1991; Carter and Shackley, 2007; Frahm, 2014; Odell, 2012; Poupeau et al., 2010; Prieto et al., 2019; Shackley, 2008; Shotton and Hendry, 1979). Established reference collections serve as a means to compare equivalent data obtained from stone tools to determine resource availability, distribution,

8 and potentially, stone tool provenance. Such studies allow inferences to be made concerning 9 hominin stone transport, procurement strategies, resource management, and land-use models (Bamforth, 1990; Binford, 1980; Brantingham, 2003; Braun et al., 2008a; Freeman, 1994; Hermes et al., 2001; Hovers, 2009; Jones et al., 2003; Kuhn, 1991; Laplace, 1972; Potts, 1994).

Quartz-rich rocks are among the wide variety of lithic raw materials that were exploited prehistorically by hominins. Quartzite is a hard, polycrystalline quartz-rich ( 90\%) rock with typically less than $10 \%$ accessory minerals, and has scarce intergranular porosity as a result of its metamorphic origin (Blatt et al., 2006; Howard, 2005; Pettijohn et al., 2012; Tucker, 2009). Throughout continental Africa, there is extensive evidence for hominin utilization of quartzose materials (e.g. quartz, quartzite, and quartzose sandstone) in the Early Stone Age (ESA), best exemplified by lithic assemblages from the Shungura Formation (Ethiopia) (Chavaillon, 1976; Howell et al., 1987; Merrick and Merrick, 1976), Kanjera South (Kenya) (Braun and Hovers, 2009; Plummer et al., 2009), Koobi Fora (Kenya) (Bunn, 1982; Isaac and Harris, 1978; Toth, 1982), Isimila (Tanzania) (Howell, 1961; Howell et al., 1962; Howell and Clark, 1963), the Lusso Beds

22 (Democratic Republic of Congo) (Harris et al., 1987), Kamoa (Democratic Republic of Congo) 23 (Cahen, 1975), the Chiwondo Beds (Malawi) (Kaufulu and Stern, 1987), Kalambo Falls (Zambia) 

and Kuman, 2015), Swartkrans (South Africa) (Kuman, 1996; Kuman and Field, 2009), and Wonderwerk (South Africa) (Chazan et al., 2012). Oldupai Gorge’s (Tanzania) Bed I and II sites

27 have also yielded widespread evidence for hominin quartzite utilization (Leakey, 1971). Quartzite may have been favored for its hardness and edge durability, which suggests that hominins employed a different management strategy in terms of procurement, transport, and knapping for this rock type (Hay, 1976). However, limited efforts have been devoted towards the systematic characterization of quartz-rich source areas throughout much of Africa, including Oldupai Gorge where most prior studies have relied on macroscopic, petrographic, and geochemical approaches but have not studied large reference collections (Blumenschine et al., 2008; Hay, 1976; Jones, 1994; Kyara, 1999; Leakey, 1971; McHenry and de la Torre, 2018; Santonja et al., 2014; Stiles, 1991, 2003; Stiles et al., 1974; Tactikos, 2005). Furthermore, some of these aforementioned studies (e.g. Blumenschine et al., 2008; Kyara, 1999; Leakey, 1971; Tactikos, 2005) have strictly relied on qualitative macroscopic traits (e.g. color, mineral composition, and groundmass), that, if used in isolation, can be unreliable for classification and interpreting stone provenance (Calogero, 1992; prehistorically available. A geological reference collection was established by sampling local quartzite-bearing outcrops. Samples were classified into discrete Raw Material Groups (RMG), 44 according to their macroscopic traits, and characterized using thin section petrography and Energy-

In this study, we use a multi-scalar approach to fingerprint five quartzitic outcrops at Oldupai Gorge as part of a wider effort to fully characterize the lithic raw materials that were Dispersive X-ray Fluorescence (EDXRF) spectroscopy. Our results suggest that some quartzitic outcrops can be differentiated from each other using a multi-proxy approach. Altogether, this study 
47 provides a needed baseline for future studies to best interpret hominin raw material selective

48 criteria, stone transport, as well as, on a broader scale, hominin palaeoecology and social behavior

49 in the Oldupai palaeobasin.

50 2. Study Area

\subsection{Geological Setting}

53 characterized by an amagmatic Western Branch and a magmatic Eastern Branch that were coeval

54 in their earliest rifting episodes (Roberts et al., 2012). Within Tanzania, the magmatic Eastern

55 Branch flanks the centrally located Tanzania Craton, and splays into a diffuse network of rifted

56 segments that are together known as the North Tanzania Divergence Zone (NTDZ) (Baker et al.,

57 1972; Dawson, 1992; Foster et al., 1997). Tanzania's geology is sub-divided into five main

58 tectono-stratigraphic units, namely Archaean cratonic rocks, Proterozoic sedimentary covers and

59 metamorphic terranes, Neoproterozoic metamorphic rocks, Phanerozoic sedimentary basins, and

60 Neogene volcanic rocks (Kasanzu et al., 2008).

The Archaean Tanzania Craton (Fig. 1a) is a stable continental crust and primarily consists

62 of granitic rocks and greenstone belts. The craton is sub-divided into three units which includes

63 the southernmost Dodoman Belt, and the central Nyanzian and northernmost Kavirondian

64 Supergroups (Kasanzu et al., 2008; Cahen et al., 1984). These units consist of 1) high- and low-

65 grade supracrustal metamorphic rocks; 2) six east-west trending greenstone belts, other

66 metamorphic rocks, and banded ironstone, and 3) sedimentary and metamorphic rocks,

67 respectively (Cahen et al., 1984; Kabete et al., 2012; Sanislav et al., 2014). 

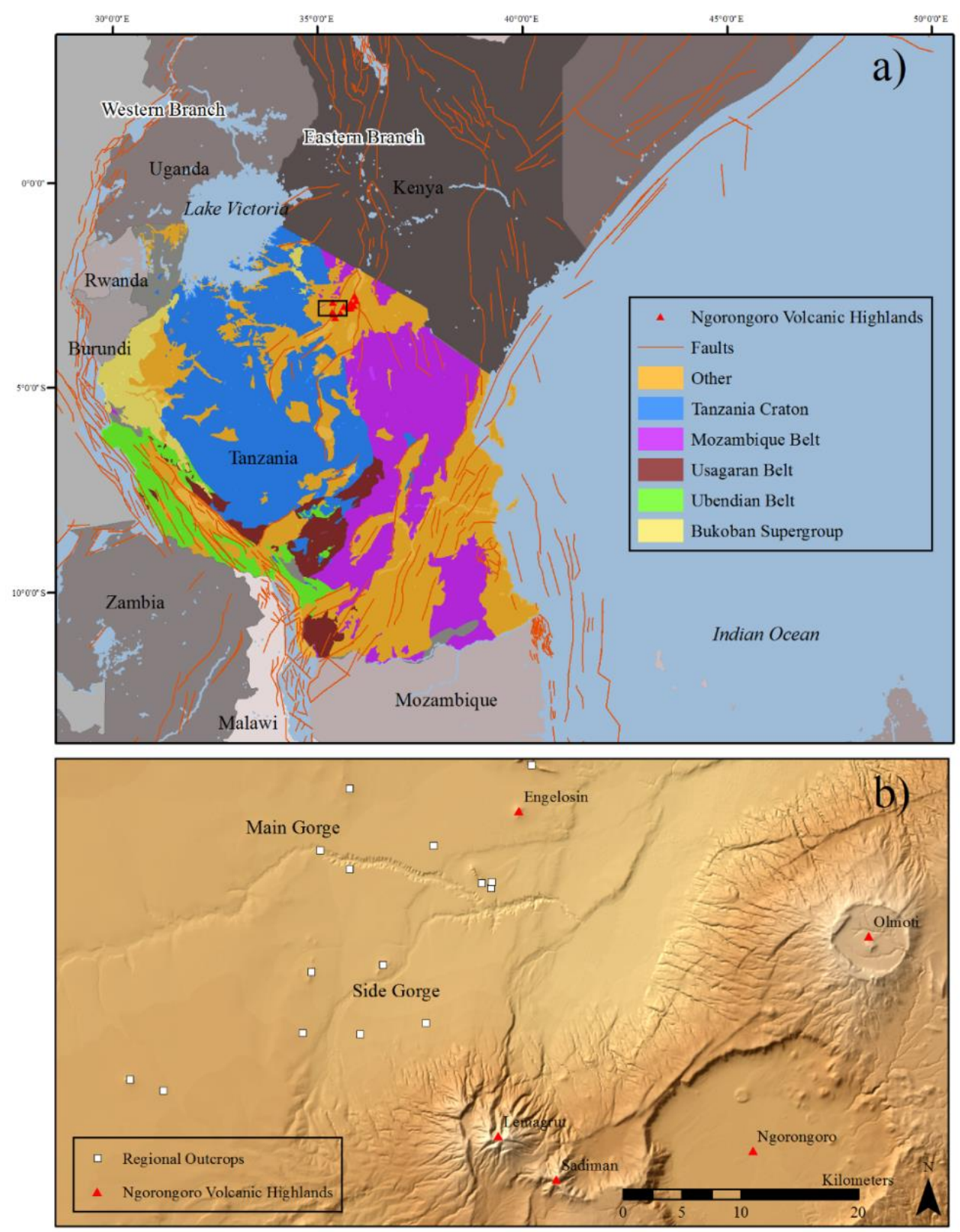

68

69 Fig. 1. a) The East African Rift System superimposed over the Tanzania Craton, the Bukoban

70 Supergroup, orogenic belts, and other units. Black outlined polygon represents the study area in

71 b). Geospatial data from Fritz et al. (2013) and Macgregor (2015); b) Location of the study area,

72 regional outcrops of varied lithologies, and the volcanic centers belonging to the Ngorongoro

73 Volcanic Highlands that directly drained into the Oldupai palaeobasin. 2-column fitting image. 
The Tanzania Craton is bordered by several mobile belts, namely the Kibaran to the west,

the Ubendian to the southwest, the Usagaran to the south, and the Mozambique to the east (Fig. 1a). The north-south trending Mozambique Belt was formed by the collision of East and West Gondwana as part of the Pan-African Orogeny between 850-550 Ma (Cahen et al., 1984; Fritz et al., 2013; Hepworth, 1972; Holmes, 1951; Kröner and Stern, 2005). Approximately 180 Ma, the Mozambique Belt was uplifted as a result of the breakup of the supercontinent Gondwana (Scoon, 2018). In northern Tanzania and southern Kenya, the Mozambique Belt is sub-divided into two lithological units, with the uppermost unit consisting of limestones, schists, gneisses, quartzites, and migmatites (Cahen and Snelling, 1966). The Gol Mountains in northern Tanzania belong to this upper unit (Cahen and Snelling, 1966; Cahen et al., 1984; Dawson, 2008; Scoon, 2018).

In the NTDZ, rift-associated volcanism initiated approximately $8 \mathrm{Ma}$ which led to the diachronic formation of the Ngorongoro-Kilimanjaro transverse volcanic belt (Dawson, 2008). This volcanic belt is over 200 kilometers wide and its volcanic centers are aligned along four axes that show a diachronous eastward migration of magmatism (Dawson, 2008; Le Gall et al., 2008). The Ngorongoro Volcanic Highlands (NVH) are located in north-central Tanzania and represent the northeastern-most portion of Neogene volcanism in the country. This volcanic massif is centered around the Ngorongoro Caldera (2.25-2.01 Ma), and also includes the centers of Sadiman (4.63-3.5 Ma), Engelosin (3-2.7 Ma), Lemagrut (2.4-2.2 Ma), Olmoti (2.01-1.80 Ma), Oldeani (1.61-1.52 Ma), Loolmasin (1.4-1.3 Ma), Olsirwa (1.4-1.3 Ma), Embagai (1.52-0.5 Ma), Kerimasi (1.10-0.08 Ma), Oldoinyo Lengai (150 Ka-present), and Loguwinywo (?-? Ma) (Dawson, 2008; Greenwood, 2014; Mollel and Swisher III, 2012).

The strata exposed at Oldupai Gorge were deposited in an endorheic basin formed by PlioPleistocene uplift in the NVH (Hay, 1976). Five volcanic centers directly drained into the Oldupai 
97 palaeobasin, namely Sadiman, Engelosin, Lemagrut, Ngorongoro, and Olmoti (McHenry and de

98 la Torre, 2018) (Fig. 1b). These centers supplied a variety of volcanic igneous rocks ranging from

99 nephelinitic, phonolitic, basaltic, rhyolitic, trachytic, and andesitic lithologies, all of which were

100 available to hominins (Hay, 1976; McHenry and de la Torre, 2018; Mollel and Swisher III, 2012).

101 In addition to these volcanic sources, the regional palaeolandscape also hosted metamorphic

102 outcrops, occurring primarily as inselbergs of lithologies associated with the Mozambique Belt

103 (Fig. 1b). In all probability, these mostly quartzitic inselbergs served as the primary sources of

104 metamorphic rocks used in artifact production (Hay, 1976). Five of these quartzite-bearing

105 outcrops were sampled for this study. The sampling locales (Fig. 2a-f) include: Naisiusiu, located

106 over ten kilometers west of the junction between the Main and Side Gorge; Endonyo Osunyai,

107 which is more than two kilometers north of the Main Gorge; and Oittii, Naibor Soit Kubwa, and

108 Naibor Soit Ndogo, which are located between approximately one to two kilometers north of the

109 junction.

Hay (1976) described and analyzed rock samples from some of the outcrops that are the

111 subject of our study. Naisiusiu yields fine- to coarse-grained granite gneiss, as well as medium-

112 grained white quartzite composed of quartz, muscovite, garnet, kyanite, and staurolite. Hay (1976)

113 did not study material from Oittii, but characterized the largest of the two Naibor Soit inselbergs

114 as a source for coarse-grained white, pale brown, and green quartzite with foliated and lineated

115 micas, and a mineral composition of quartz and muscovite (Hay, 1976). Endonyo Osunyai yields

116 coarse-grained quartzite that is similar to material from the largest of the two Naibor Soit 117 inselbergs and is located four kilometers to its northwest (Hay, 1976). 

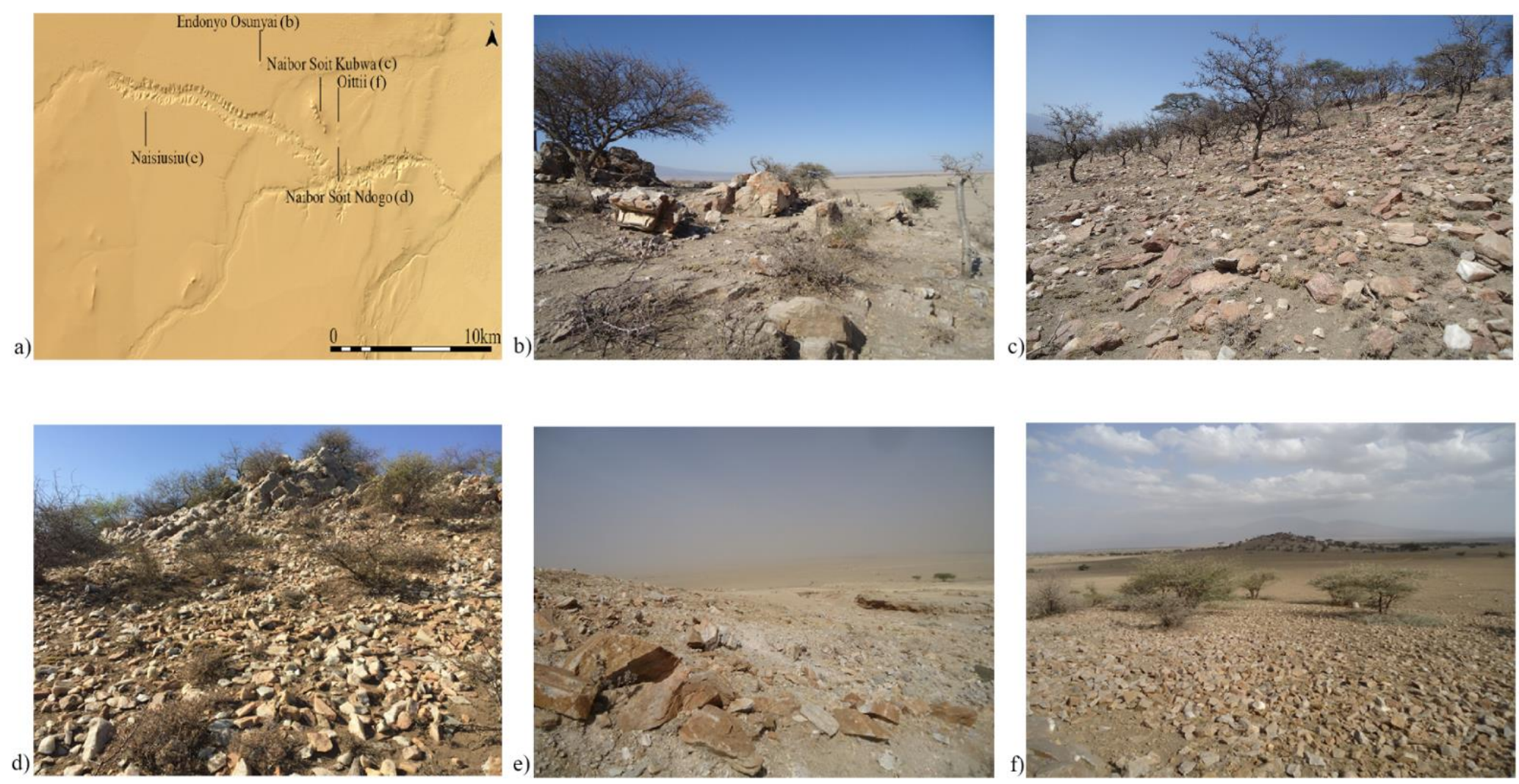

119 Fig. 2. a) Location of the five quartzitic outcrops sampled for this study; b) Endonyo Osunyai, poorly exposed quartzitic and gneissic outcrop; c) Naibor Soit Kubwa, $\sim 1.8$ km-long northwest-southeast trending quartzitic and gneissic inselberg; d) Naibor Soit Ndogo, 1

121 km-long northwest-southeast trending quartzitic inselberg; e) Naisiusiu, low-lying quartzitic, schistic, and meta-granitic outcrop; f)

122 Oittii, low-lying quartzitic and schistic outcrop. 2-column fitting image. 
More recently, McHenry and de la Torre (2018) studied lithic assemblages from HWK EE and EF-HR in which they classified quartzites into nine RMGs (Supplementary Materials, Table 1) complemented by petrographic and geochemical characterization of specimens from Naibor Soit and Naisiusiu. They noted that Naibor Soit quartzite is composed of quartz and rare muscovite, whereas Naisiusiu quartzite is composed of quartz, rare muscovite, and rare microcline (McHenry and de la Torre, 2018).

\subsection{Oldupai's Raw Materials: An Overview}

Oldupai Gorge's sedimentary sequence (Bed I-IV, Masek, Ndutu, and Naisiusiu) has yielded an exceptional quantity of Early, Middle, and Later Stone Age lithic assemblages (Hay, 1976; Leakey, 1971; Leakey et al., 1972; Leakey and Roe, 1994). ESA lithics were primarily manufactured from igneous and metamorphic rocks, and occasionally, from local authigenic chert that was intermittently exposed at lowstands in Bed II (Hay, 1976; Leakey, 1971; Stiles et al., 1974). In Bed I and II, early hominins appear to have employed different technological strategies depending on the raw material, as there is an abundance of igneous cores and a lack of knapping products, while there is an abundance of quartzite flakes but a scarcer number of cores (Leakey, 1971). Altogether, this suggests that hominins may have employed a high degree of curation for small quartzite lithics and large igneous cores (Hay, 1976; Leakey, 1971; Schick, 1987; Toth, 1985). Based on this rich archaeological record, it has been recognized that early hominins transported stone in the Oldupai palaeobasin up to twelve kilometers away from their eventual point of discard (Hay, 1976; Leakey, 1971).

Experimental studies seeking to reproduce Acheulean bifaces and determine their butchering efficiencies using local raw materials (e.g. quartzite, basalt, trachyandesite, and phonolite) have found the latter to varyingly influence production time, reduction strategies, 
146 finished forms, and edge durability (Jones, 1979, 1980, 1981, 1994). These studies have also

147 served as an important reference into the distribution of stone sources along with their natural

148 morphometries and mechanical properties, which are key to interpret technological behavior

149 (Jones, 1979, 1980, 1981, 1994).

In recent years, prolific geological studies have been conducted in the NVH (Dawson, 2008;

151 Greenwood, 2014; Mana et al., 2012; McHenry et al., 2008; Mollel, 2002, 2007; Mollel et al., 152 2008; Mollel et al., 2009; Mollel and Swisher III, 2012; Zaitsev et al., 2012). This makes it possible 153 to determine from which volcanic center the raw materials employed for artifact manufacture 154 ultimately came from, but not the location from where they were precisely sourced by early 155 hominins. However, characterization studies of the regional metamorphic inselbergs have been

156 limited. Many studies assume that the larger of the two Naibor Soit inselbergs was the primary 157 source of quartzite in the eastern palaeobasin (Blumenschine et al., 2008; Hay, 1976; McHenry 158 and de la Torre, 2018; Schick, 1987). In light of this, we sampled five of the most prominent 159 quartzite-bearing sources on the modern Oldupai landscape. These outcrops were likely frequented 160 by early hominins for raw materials since they were available in the Pleistocene and were close to 161 known sites, according to the high frequency of quartzite lithics in archaeological collections 162 (Leakey, 1971; Leakey and Roe, 1994). Therefore, the characterization of quartzite sources will 163 help to establish resource availability, and act as a referential framework for future provenance 164 studies.

\section{3. Materials and Methods}

Over the last two years, our research team surveyed outcrops in the greater Oldupai region.

167 Samples were collected in primary (e.g. outcrop, geologic formation) and secondary (e.g. drainage 168 sump, riverbed) positions in order to fully characterize intra- and inter-outcrop lithological 
variation. Our reference collection currently consists of 271 rock samples curated by the Stone Tools, Diet, and Sociality project in the Tropical Archaeology Lab (TAL; Earth Sciences 811, University of Calgary). Sampled quartzitic outcrops include Endonyo Osunyai $(n=4)$, Naibor Soit Kubwa $(n=104)$, Naibor Soit Ndogo $(n=27)$, Naisiusiu $(n=7)$, and Oittii $(n=5)$. The variability in the number of samples from a given outcrop is a direct representation of its size, macroscopic heterogeneity or lack thereof, and of our ongoing efforts to fully understand the lithological and geochemical variation of the two Naibor Soit inselbergs, as these are most prominent outcrops in the eastern Oldupai palaeobasin.

This study summarizes a multi-scalar fingerprinting approach we took to understand the availability and variability of different quartzite sources in the Oldupai region. We macroscopically analyzed 147 samples and classified them into twelve RMGs. Following this, a representative sample from each RMG was petrographically characterized, and the geochemical profiles of 30 samples were determined using EDXRF spectroscopy.

\subsection{Field Sampling and Reference Collection}

Geoarchaeological surveys were designed based on a literature review of known quartzitic outcrops in combination with digital cartographic data (i.e. geological and topographic maps, orthophotos, and satellite imagery), and knowledge that members of local Maasai communities shared with us on the spatial distribution of regional outcrops. While sampling each outcrop, rocks were selected based on diverse macroscopic characteristics in order to obtain a sample population representative of intra-outcrop variability. A geological hammer was used to extract a sample, after which these were labelled and photographed, and the outcrop characteristics documented. GPS coordinates of sample locations were recorded using a Garmin eTrex 10.

\subsection{Macroscopic Classification and Petrographic Analysis}


Data collected in the field were first uploaded into a georeferenced database. Afterwards, 193 each sample within our reference collection was measured and weighed (Table 1), and 194 macroscopically analyzed. Macroscopic criteria included color/s by referencing the Munsell Rock 195 Color Booklithology, morphology (tabular, angular, sub-angular, sub-tabular, subrounded or 196 rounded blanks), grain size (Table 2), texture, gloss, transparency, mineral composition, 197 impurities, and post-depositional alterations (Supplementary Materials Table 2) (Demars, 1982; 198 Howard, 2005). A total of 147 quartzite samples were categorized into four quartzite types (R199 Red; W-White; Gr-Gray; G-Green), and into an additional twelve RMGs (R1-R5; W1-W4; GR1200 GR2; G1) based on distinct macroscopic traits, most notably color, grain size, texture, and mineral 201 composition. The use of the term RMG was preferred over the term Raw Material Unit (RMU) as 202 we intend to determine the availability and variability of quartzites rather than perform a temporal 203 reconstruction of knapping sequences or identify refits (Roebroeks, 1998; Vaquero and Pasto, 204 2001; Vaquero, 2008).

\begin{tabular}{|l|l|l|l|l|l|}
\hline RMG & $\begin{array}{c}\text { Samples } \\
(\mathbf{n})\end{array}$ & $\begin{array}{c}\text { Length } \\
(\overline{\mathbf{x}} ; \mathbf{~ m m})\end{array}$ & $\begin{array}{c}\text { Width } \\
(\overline{\mathbf{x}} ; \mathbf{~ m m})\end{array}$ & $\begin{array}{c}\text { Thickness } \\
(\overline{\mathbf{x}} ; \mathbf{m m})\end{array}$ & $\begin{array}{c}\text { Total Weight } \\
(\mathbf{g})\end{array}$ \\
\hline R1 & 11 & 90.9 & 63.9 & 39.1 & 3365.46 \\
\hline R2 & 3 & 92.6 & 63.3 & 37 & 1255.24 \\
\hline R3 & 30 & 83.4 & 64.8 & 44 & 8822.90 \\
\hline R4 & 14 & 95 & 63.6 & 43.5 & 4185.67 \\
\hline R5 & 1 & 80 & 60 & 46 & 286 \\
\hline W1 & 12 & 92 & 64.4 & 43 & 3765.62 \\
\hline W2 & 9 & 95.4 & 74.8 & 45 & 2739.29 \\
\hline W3 & 29 & 86.4 & 60.5 & 35.7 & 5771.31 \\
\hline W4 & 2 & 80 & 56.5 & 33 & 107.42 \\
\hline GR1 & 14 & 90.9 & 59.9 & 43.8 & 3802.06 \\
\hline GR2 & 7 & 90.3 & 68.4 & 34.7 & 1190.95 \\
\hline G1 & 15 & 85.4 & 59.7 & 33.2 & 3868.59 \\
\hline
\end{tabular}

205 Table 1. Number of samples, average size dimensions, and total weight per RMG. 


\begin{tabular}{|l|l|}
\hline \multicolumn{1}{|c|}{ Grain Size } & Values $(\mathbf{m m})$ \\
\hline Fine-grained & $<3$ \\
\hline Medium-grained & $3-5$ \\
\hline Coarse-grained & $5-10$ \\
\hline Very coarse-grained & $>10$ \\
\hline
\end{tabular}

206 Table 2. Grain size scale used for macroscopic analyses.

207

208

209

210

211

212

213

214

215

216

$217=5$; Naisiusiu = 7; Oittii = 5) from eight RMGs were analyzed using a Thermo Scientific $A R L$

Representative samples from each RMG were thin sectioned in the TAL. A total of twelve samples were cut flat (IsoMet 4000 Linear Precision Saw), mounted (Cast N' Vac 1000 Castable Vacuum System) on frosted slides (27x46 mm) using epoxy resin (Buehler EpoThin 2), ground (PetroThin Thin Sectioning System) to $\sim 30 \mu \mathrm{m}$, and polished (Metaserv 2000 Grinder Polisher).

Uncovered thin sections were analyzed using a polarizing microscope (Leitz HM-POL; 2.5-40 x) to determine their mineral composition, modes, textures, and crystal habits (Folk, 1980; Melgarejo, 1997; Pettijohn et al., 1974; Perkins, 2002). Photomicrographs were taken using a Nikon ECLIPSE 50i POL microscope (2-40 x) equipped with a Moticam 2500 (Motic Images Plus 2.0).

\subsection{EDXRF}

A total of 30 samples (Endonyo Osunyai = 4; Naibor Soit Kubwa = 9; Naibor Soit Ndogo

218 Quant'X EDXRF spectrometer in the McMaster Archaeological XRF Lab (MAX Lab). Prior to 219 analysis, samples were cut into cubes $\left(30 \mathrm{~mm}^{2} /\right.$ face $)$ using a Trim Saw (TS10, Lortone Inc.) in the 220 TAL to obtain planar surfaces to reduce X-ray scattering. In the MAX Lab, samples were placed 221 in individual glass beakers, immersed with distilled water, and cleaned in an ultrasonic tank for 222 ten minutes. After completion, samples were air dried, then positioned and secured on the 223 spectrometer's sample tray. Each sample tray run for this study included the RGM-2 reference 224 standard (USGS) which was analyzed alongside our samples to ensure instrumentation calibration. 
The EDXRF spectrometer is equipped with an end window Bremsstrahlung, air cooled, Rh target, 50-watt, X-ray tube with a $\leq 7.6 \mu \mathrm{m}(0.3 \mathrm{mil})$ beryllium $(\mathrm{Be})$ window, an X-ray generator that operates from 4-50 kV in $1 \mathrm{kV}$ increments (current range, $0-1.98 \mathrm{~mA}$ in $0.02 \mathrm{~mA}$ increments), and an Edwards RV8 vacuum pump for the analysis of elements below titanium (Ti). Data are acquired with a pulse processor and analog to digital converter. In these preliminary stages of regional quartzite characterization, an all-encompassing analytical method was run in order to obtain the concentrations of eight major elements and ten trace elements under an automated series of six analytical conditions (Table 3). Major elements $\left(\mathrm{SiO}_{2}, \mathrm{TiO}_{2}, \mathrm{Al}_{2} \mathrm{O}_{3}, \mathrm{Fe}_{2} \mathrm{O}_{3}, \mathrm{MnO}, \mathrm{MgO}\right.$, $\mathrm{CaO}$, and $\left.\mathrm{K}_{2} \mathrm{O}\right)$ were measured as oxides in weight $\%$ and trace elements $(\mathrm{Cu}, \mathrm{Zn}, \mathrm{Rb}, \mathrm{Sr}, \mathrm{Y}, \mathrm{Zr}$, $\mathrm{Nb}, \mathrm{Ba}, \mathrm{Pb}$, and $\mathrm{Th}$ ) were measured in ppm. X-ray intensities of elements were converted to concentrations using a least-squares calibration line ratioed to the Compton scatter established for each element from the analysis of international rock standards. These include AGV-2 (andesite), BCR-2 (basalt), BHVO-2 (hawaiite), BIR-1a (basalt), GSP-2 (granodiorite), JR-1 (obsidian), JR2 (obsidian), QLO-1 (quartz latite), RGM-2 (rhyolite), SDC-1 (mica schist), STM-2 (syenite), TLM-1 (tonalite), and W-2a (diabase).

\begin{tabular}{|l|l|l|l|l|}
\hline \multicolumn{1}{|c|}{ Condition } & \multicolumn{1}{|c|}{ Filter } & \multicolumn{1}{c|}{ Voltage } & \multicolumn{1}{c|}{ Atmosphere } & \multicolumn{1}{c|}{ Analytes } \\
\hline High $\mathrm{Zb}$ & $\mathrm{Cu}$ Thick & $49 \mathrm{kV}$ & Air & $\mathrm{Ba}$ \\
\hline Mid $\mathrm{Zb}$ & Pd Med & $20 \mathrm{kV}$ & Air & $\mathrm{Cu}, \mathrm{Zn}$ \\
\hline Mid $\mathrm{Zc}$ & Pd Thick & $28 \mathrm{kV}$ & Air & $\mathrm{Rb}, \mathrm{Sr}, \mathrm{Y}, \mathrm{Zr}, \mathrm{Nb}, \mathrm{Pb}, \mathrm{Th}$ \\
\hline Low $\mathrm{Za}$ & No Filter & $4 \mathrm{kV}$ & Vacuum & $\mathrm{Mg}, \mathrm{Al}, \mathrm{Si}$ \\
\hline Low $\mathrm{Zb}$ & Cellulose & $8 \mathrm{kV}$ & Vacuum & $\mathrm{Ca}, \mathrm{K}$ \\
\hline Low $\mathrm{Zc}$ & Aluminum & $14 \mathrm{kV}$ & Vacuum & $\mathrm{Mn}, \mathrm{Ti}, \mathrm{Fe}$ \\
\hline
\end{tabular}

Table 3. Analytical conditions for EDXRF analyses.

The resulting data were imported to Microsoft Excel where these were normalized to the reference standard (RGM-2) using the Min-Max scaling method (Xnorm $=\mathrm{X}-\mathrm{Xmin} /$ 

255 results.

$\mathrm{Xmax}-\mathrm{Xmin}$ ) prior to its interrogation and plotting. This procedure ensures that results are consistent in relation to the reference standard, thereby allowing for accurate comparative analyses among data. Kendall's Tau, employing Monte Carlo permutation tests (N=9999) and and KruskalWallis tests were performed in PAST 3.22 to understand the dependence and degree of variance among all elements by outcrop. With each sample classified by outcrop and RMG, Analyses (PCA), , and after confirming the adequacy of our data through the Kaiser-Meyer-Olkin (KMO) index, two Principal Component Analyses (PCA) were performed in R (R Core Team, 2017) using Factominer (Lê et al., 2008) and Factoextra (Kassambara and Mundt, 2017) packages to explore the segregation power of the geochemical data, as well as to identify factor loadings and variable correlations. Discriminant Function Analyses (DFA) were also performed using the classification by outcrop and RMG to confirm the discriminatory power of the geochemical and macroscopic data, showing the statistical significance of the differences, and predicting a model to unknown

\section{Results}

\subsection{Macroscopic and Petrographic Characterization}

Macroscopic analyses of 147 quartzite samples allowed us to identify four types (Red-R; White-W; Gray-Gr; Green-G) that were further classified in twelve RMGs (R1-R5; W1-W4; GR1GR2; G1) (Table 4; Supplementary Materials Table 2). These are described below.

\subsubsection{Red Quartzites (R1-R5)}

Red quartzites are red to brown in color and occasionally oxidized, fine- to very coarsegrained, and samples have tabular to sub-angular morphologies with occasional plane fractures (Fig. 3). They are characterized by inequigranular and generally interlocked quartz crystals, white micas, and opaque minerals. Differences in color, grain size, and texture allowed us to identify 
five RMGs (Table 4). Under thin section, quartz crystals are inequigranular and anhedral, have

267 sutured boundaries, and display undulatory extinction. Muscovite crystals have a platy or plumose

268 habit, are either interstitial or embedded in quartz, and display a parallel to sub-parallel lineation.

269 Hematite ranges from massive to fine, with the latter predominantly interstitial. Rare rutile and

270 biotite are present depending on the RMG (Table 4).

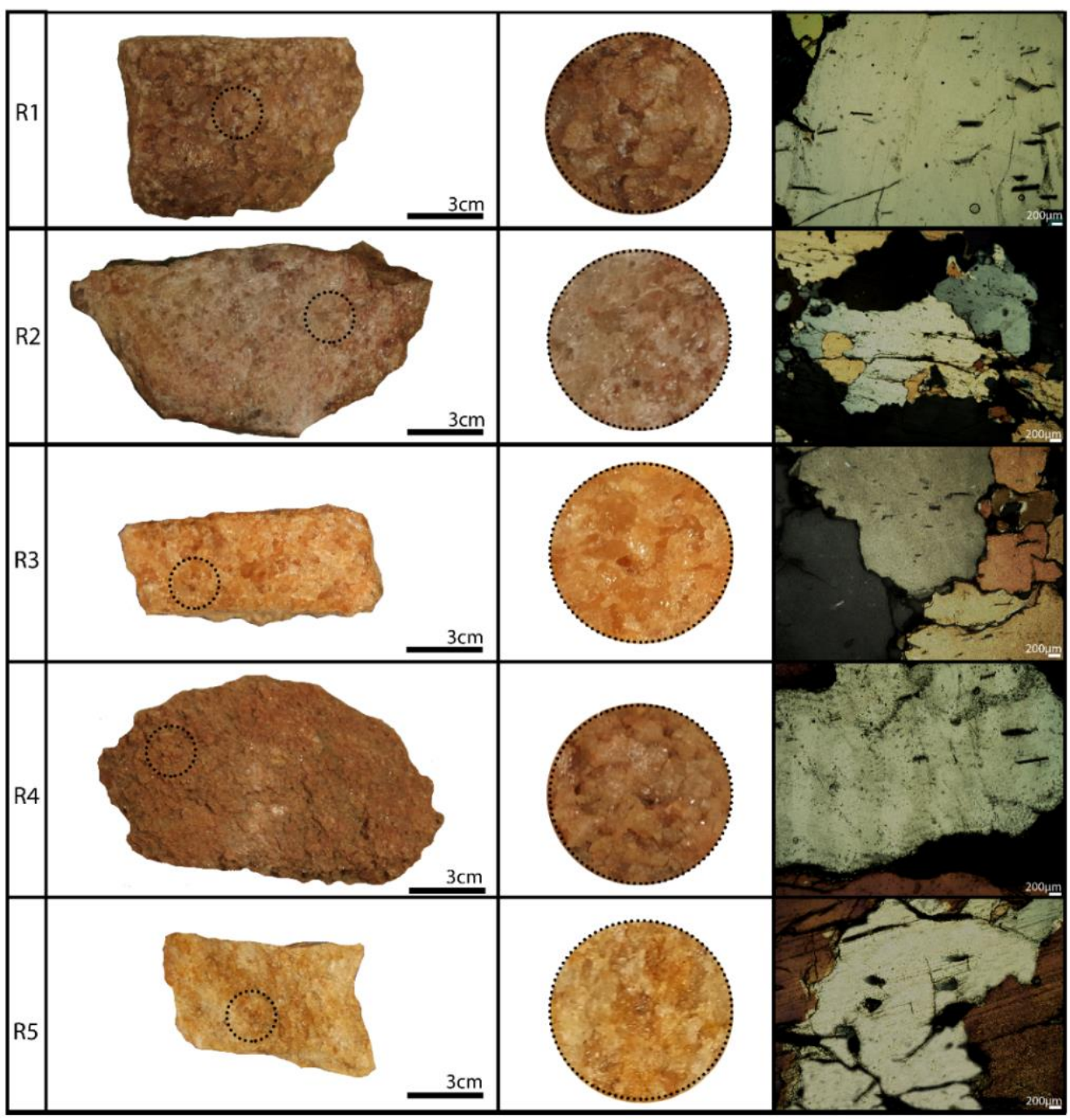

271

272 Fig. 3. Red Quartzites (RMG R1-R5): Macroscopic textures and photomicrographs under cross-

273 polarized light. 2-column fitting image. 


\subsubsection{White Quartzites (W1-W4)}

White quartzites are white to pinkish, medium- to very coarse-grained, and samples have

276 tabular to sub-angular morphologies (Fig. 4). They are characterized by interlocked and anhedral

277 quartz crystals, white micas, and opaque minerals. Differences in color, grain size, texture, and

278 mineral composition allowed us to identify four RMGs (Table 4). Under thin section, quartz

279 crystals are inequigranular, anhedral, have sutured boundaries, and display undulatory extinction.

280 Muscovite crystals have platy habits, are either interstitial or embedded in quartz, and display a

281 parallel to sub-parallel lineation. Hematite ranges from massive to fine, with the latter

282 predominantly interstitial. Rutile is present in one RMG (Table 4).

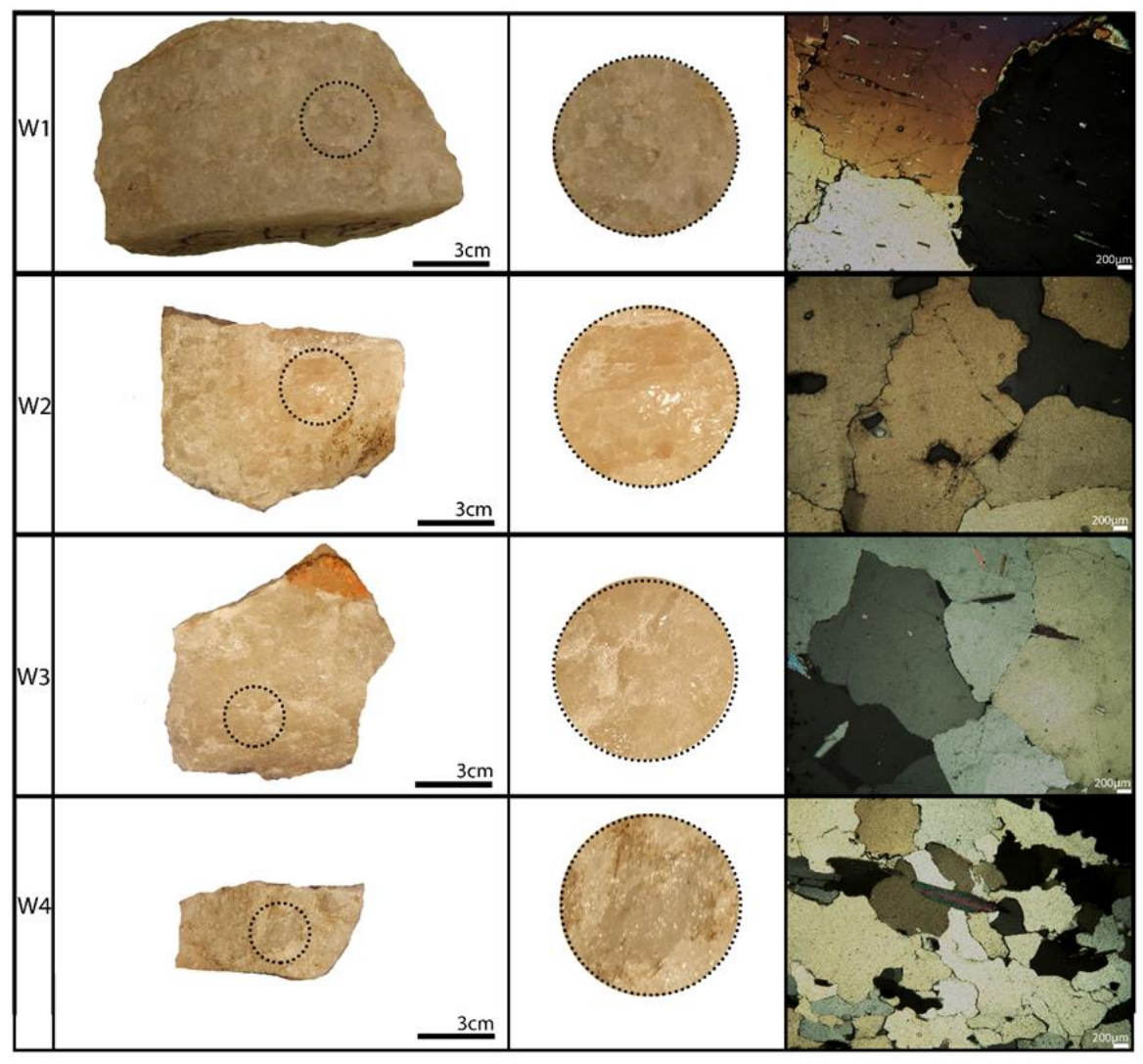

284 Fig. 4. White Quartzites (RMG W1-W4): Macroscopic textures and photomicrographs under cross-polarized light. 2-column fitting image. 


\subsubsection{Gray Quartzites (GR1-GR2)}

Gray quartzites are gray to pale blue, fine- to coarse-grained, and samples have sub-angular

288 morphologies with occasional plane fractures (Fig. 5). They are characterized by interlocked

289 quartz crystals, white micas, and opaque minerals that are responsible for dark zonations (Table

290 4). Differences in color, grain size, and texture allowed us to identify two RMGs (Table 4). Under

291 thin section, quartz crystals are inequigranular, anhedral, occasionally weakly foliated,

292 characterized by sutured boundaries, and display undulatory extinction. Muscovite crystals have

293 platy habits that are either interstitial or embedded in quartz, and display a parallel to random

294 lineation. Hematite ranges from massive to fine, and rutile is rare in both RMGs (Table 4).

295

296

297

298

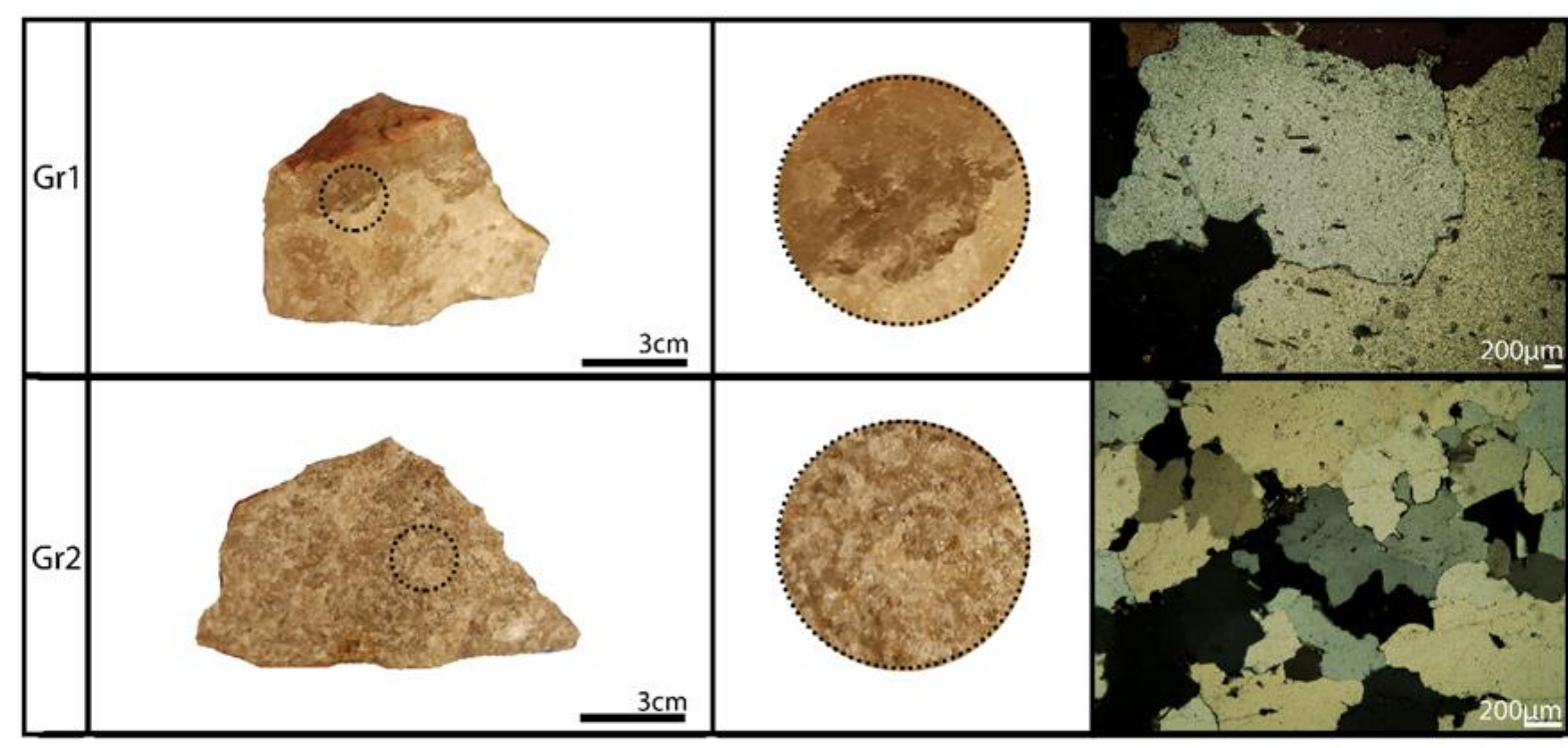

Fig. 5. Gray Quartzites (RMG GR1-GR2): Macroscopic textures and photomicrographs under cross-polarized light. 2-column fitting image.

\subsubsection{Green Quartzites (G1)}




\begin{tabular}{|c|c|c|c|c|}
\hline Type & RMG & Macroscopic Analysis & Petrographic Analysis & Outcrop \\
\hline \multirow{5}{*}{$\begin{array}{l}\text { Red Quartzites } \\
\text { (R) }\end{array}$} & $\mathbf{R 1}$ & $\begin{array}{l}\text { 5YR 7/2 Grayish Orange Pink; 5YR 6/4 Light Brown; } \\
\text { 5YR 5/6 Light Brown } \\
\text { Tabular blocks } \\
\text { Very coarse-grained } \\
\text { Interlocking quartz } \\
\text { Mica }\end{array}$ & $\begin{array}{l}\text { Quartz (90\%), inequigranular, undulatory extinction } \\
\text { Muscovite (5\%), platy, inter- and intra-crystalline, parallel lineation } \\
\text { Hematite (5\%), fine, inter-crystalline } \\
\text { Sample ID: NSK C4A }\end{array}$ & $\begin{array}{c}\text { Naibor Soit } \\
\text { Kubwa } \\
\text { Naibor Soit } \\
\text { Ndogo }\end{array}$ \\
\hline & $\mathbf{R 2}$ & $\begin{array}{l}\text { 5YR 6/4 Light Brown; 5R 4/2 Grayish Red } \\
\text { Tabular blocks, plane fractures } \\
\text { Medium- to coarse-grained } \\
\text { Interlocking quartz } \\
\text { Mica } \\
\text { Opaque minerals }\end{array}$ & $\begin{array}{l}\text { Quartz (90\%), inequigranular, sutured boundaries } \\
\text { Quartz (5\%), anhedral, inter-crystalline between sutured boundaries } \\
\text { Muscovite (3\%), platy and plumose, sub-parallel lineation } \\
\text { Hematite (2\%), fine, inter-crystalline } \\
\text { Sample ID: NSK G9A }\end{array}$ & $\begin{array}{c}\text { Naibor Soit } \\
\text { Kubwa } \\
\text { Naibor Soit } \\
\text { Ndogo }\end{array}$ \\
\hline & $\mathbf{R 3}$ & $\begin{array}{l}\text { 5YR 6/4 Light Brown; 5R 4/2 Grayish Red; 5Y 8/1 } \\
\text { Yellowish Gray; 5YR 8/4 Grayish Brown } \\
\text { Tabular blocks } \\
\text { Fine- to medium- to coarse-grained } \\
\text { Interlocking quartz } \\
\text { Mica } \\
\text { Opaque minerals }\end{array}$ & $\begin{array}{l}\text { Quartz (93\%), inequigranular } \\
\text { Muscovite (5\%), platy, inter- and intra-crystalline, parallel lineation } \\
\text { Hematite (1\%), fine, inter-crystalline } \\
\text { Rutile (1\%), prismatic, high-relief, dark red } \\
\qquad \text { Sample ID: Naibor Soit Kubwa } 1\end{array}$ & $\begin{array}{l}\text { Endonyo } \\
\text { Osunyai } \\
\text { Naibor Soit } \\
\text { Kubwa } \\
\text { Naibor Soit } \\
\text { Ndogo }\end{array}$ \\
\hline & $\mathbf{R 4}$ & $\begin{array}{l}\text { 5YR 6/4 Light Brown; 5YR 5/6 Light Brown } \\
\text { Sub-angular blocks, sub-parallel plane fractures and } \\
\text { crystal disaggregation } \\
\text { Very coarse-grained } \\
\text { Interlocking quartz } \\
\text { Mica }\end{array}$ & $\begin{array}{l}\text { Quartz (96\%), inequigranular } \\
\text { Muscovite (3\%), platy, parallel lineation } \\
\text { Hematite (1\%), fine, inter-crystalline } \\
\text { Sample ID: NSK K12B }\end{array}$ & $\begin{array}{c}\text { Naibor Soit } \\
\text { Kubwa }\end{array}$ \\
\hline & $\mathbf{R 5}$ & $\begin{array}{l}\text { N7 Light Gray } \\
\text { Tabular blocks, occasional plane fractures } \\
\text { Fine- to medium- to coarse-grained } \\
\text { Weakly foliated quartz } \\
\text { Mica }\end{array}$ & $\begin{array}{l}\text { Quartz (90\%), inequigranular, intense undulatory extinction } \\
\text { Muscovite (2-4\%), platy, inter- and intra-crystalline, sub-parallel lineation } \\
\text { Hematite (2-4\%), massive and fine } \\
\text { Biotite (1\%), massive and platy } \\
\text { Sample ID: Naisiusiu 1 }\end{array}$ & Naisiusiu \\
\hline \multirow[t]{2}{*}{$\begin{array}{l}\text { White Quartzites } \\
\text { (W) }\end{array}$} & W1 & $\begin{array}{l}\text { N8 Very Light Gray; } 5 \text { Y 8/1 Yellowish Gray } \\
\text { Tabular blocks } \\
\text { Coarse-grained } \\
\text { Interlocking quartz } \\
\text { Mica }\end{array}$ & $\begin{array}{l}\text { Quartz (92\%), inequigranular, undulatory extinction } \\
\text { Muscovite (5\%), platy, inter- and intra-crystalline, parallel lineation } \\
\text { Opaque minerals and hematite (3\%), massive and fine, inter- and intra-crystalline, respectively } \\
\text { Sample ID: NSK C4B }\end{array}$ & $\begin{array}{c}\text { Naibor Soit } \\
\text { Kubwa } \\
\text { Naibor Soit } \\
\text { Ndogo }\end{array}$ \\
\hline & W2 & 5YR 8/1 Pinkish Gray; 5G 6/1 Greenish Gray & Quartz (92\%), inequigranular and anhedral & $\begin{array}{c}\text { Naibor Soit } \\
\text { Kubwa }\end{array}$ \\
\hline
\end{tabular}




\begin{tabular}{|c|c|c|c|c|}
\hline & & $\begin{array}{l}\text { Tabular blocks } \\
\text { Very coarse-grained } \\
\text { Interlocking quartz } \\
\text { Mica } \\
\text { Inter-crystalline opaque minerals, some zonations }\end{array}$ & $\begin{array}{l}\text { Muscovite }(8 \%) \text {, platy, inter- and intra-crystalline, sub-parallel lineation } \\
\text { Rutile }(<1 \%) \text {, prismatic, high-relief, dark red } \\
\text { Sample ID: Naibor Soit Kubwa } 13\end{array}$ & $\begin{array}{l}\text { Naibor Soit } \\
\text { Ndogo }\end{array}$ \\
\hline & W3 & $\begin{array}{l}\text { N9 White; N7 Light Gray } \\
\text { Tabular blocks } \\
\text { Coarse-grained } \\
\text { Interlocking quartz } \\
\text { Mica, lustrous }\end{array}$ & $\begin{array}{l}\text { Quartz }(98 \%) \text {, inequigranular and anhedral, sutured boundaries, intense undulatory extinction } \\
\text { Muscovite }(2 \%) \text {, platy, inter- and intra-crystalline, sub-parallel lineation } \\
\text { Opaque minerals and hematite }(<1 \%) \text {, massive and fine } \\
\qquad \text { Sample ID: Endonyo Osunyai } 2\end{array}$ & $\begin{array}{l}\text { Endonyo } \\
\text { Osunyai } \\
\text { Naibor Soit } \\
\text { Kubwa } \\
\text { Naibor Soit } \\
\text { Ndogo } \\
\text { Naisiusiu }\end{array}$ \\
\hline & W4 & $\begin{array}{l}\text { N9 White; N7 Light Gray; 5GY 8/1 Light Greenish } \\
\text { Gray } \\
\text { Sub-angular blocks, occasionally brittle } \\
\text { Medium- to coarse-grained } \\
\text { Inequigranular quartz } \\
\text { Mica }\end{array}$ & $\begin{array}{l}\text { Quartz (90\%), inequigranular, weakly foliated, sutured boundaries, undulatory extinction, occasionally } \\
\text { cemented and overgrown } \\
\text { Quartz (5\%), anhedral } \\
\text { Muscovite (5\%), platy, inter- and intra-crystalline, sub-parallel lineation } \\
\qquad \text { Sample ID: Naisiusiu 9 } \\
\end{array}$ & $\begin{array}{c}\text { Naisiusiu } \\
\text { Oittii }\end{array}$ \\
\hline \multirow{2}{*}{$\begin{array}{l}\text { Gray Quartzites } \\
\text { (GR) }\end{array}$} & GR1 & $\begin{array}{l}\text { 5PB 5/2 Grayish Blue; 5PB } 7 / 2 \text { Pale Blue } \\
\text { Sub-angular blocks, common plane fractures } \\
\text { Medium- to coarse-grained } \\
\text { Interlocking quartz } \\
\text { Mica } \\
\text { Opaque minerals, zonations }\end{array}$ & $\begin{array}{l}\text { Quartz (95\%), inequigranular and anhedral, weakly foliated, sutured boundaries, undulatory extinction } \\
\text { Muscovite (5\%), platy, inter- and intra-crystalline, parallel lineation } \\
\text { Rutile }(<1 \%) \text {, prismatic, high-relief, dark red } \\
\text { Opaque minerals (massive hematite?) }(<1 \%) \\
\qquad \text { Sample ID: Naibor Soit Kubwa } 2\end{array}$ & $\begin{array}{l}\text { Naibor Soit } \\
\text { Kubwa } \\
\text { Naibor Soit } \\
\text { Ndogo } \\
\text { Naisiusiu }\end{array}$ \\
\hline & GR2 & $\begin{array}{l}\text { N8 Very Light Gray; N5 Medium Gray; 5YR 6/1 Light } \\
\text { Brownish Gray } \\
\text { Sub-angular blocks } \\
\text { Fine- to medium-grained } \\
\text { Interlocking quartz } \\
\text { Mica } \\
\text { Opaque minerals }\end{array}$ & $\begin{array}{l}\text { Quartz (93\%), inequigranular and anhedral, sutured boundaries, intense undulatory extinction } \\
\text { Muscovite (3\%), platy, fragmented, random lineation } \\
\text { Hematite (3\%), massive and fine } \\
\text { Rutile (1\%), prismatic, high-relief, dark red } \\
\qquad \text { Sample ID: Oittii 1A }\end{array}$ & $\begin{array}{c}\text { Endonyo } \\
\text { Osunyai } \\
\text { Naisiusiu } \\
\text { Oittii }\end{array}$ \\
\hline $\begin{array}{c}\text { Green Quartzites } \\
\text { (G) }\end{array}$ & G1 & $\begin{array}{l}\text { 5YR 7/2 Grayish Orange Pink; 5YR 6/4 Light Brown; } \\
\text { 5YR 8/1 Pinkish Gray; 5G 6/1 Greenish Gray; 5GY 8/1 } \\
\text { Light Greenish Gray; 5G 6/6 Brilliant Green } \\
\text { Tabular blocks } \\
\text { Medium- to coarse-grained } \\
\text { Interlocking quartz } \\
\text { Mica } \\
\text { Green mica }\end{array}$ & $\begin{array}{l}\text { Quartz ( } 85 \%) \text {, inequigranular and anhedral, weakly foliated, sutured boundaries, intense undulatory } \\
\text { extinction } \\
\text { Muscovite (14\%), platy and plumose, inter- and intra-crystalline, sub-parallel lineation } \\
\text { Rutile (1\%), prismatic, high-relief, dark red } \\
\text { Fuchsite (<1\%), platy, intra-crystalline, sub-parallel lineation, green } \\
\qquad \text { Sample ID: Naibor Soit Kubwa } 32\end{array}$ & $\begin{array}{c}\text { Naibor Soit } \\
\text { Kubwa } \\
\text { Naibor Soit } \\
\text { Ndogo }\end{array}$ \\
\hline
\end{tabular}

Table 4. Macroscopic and petrographic textures, grain sizes, mineral composition, and visually estimated modes for all RMGs and their source. 
Green quartzites are light to bright green, medium- to coarse-grained, and samples have tabular morphologies (Fig. 6). They are characterized by interlocked quartz along with white and green micas. We identified one RMG based on color and mineral composition (Table 4). Under thin section, quartz crystals are inequigranular, anhedral, weakly foliated, characterized by sutured boundaries, and display undulatory extinction. Muscovite crystals have platy and plumose habits, are either interstitial or embedded in quartz, and display a sub-parallel lineation. Rare rutile and green fuchsite crystals are present, with the latter responsible for green zonations (Table 4).

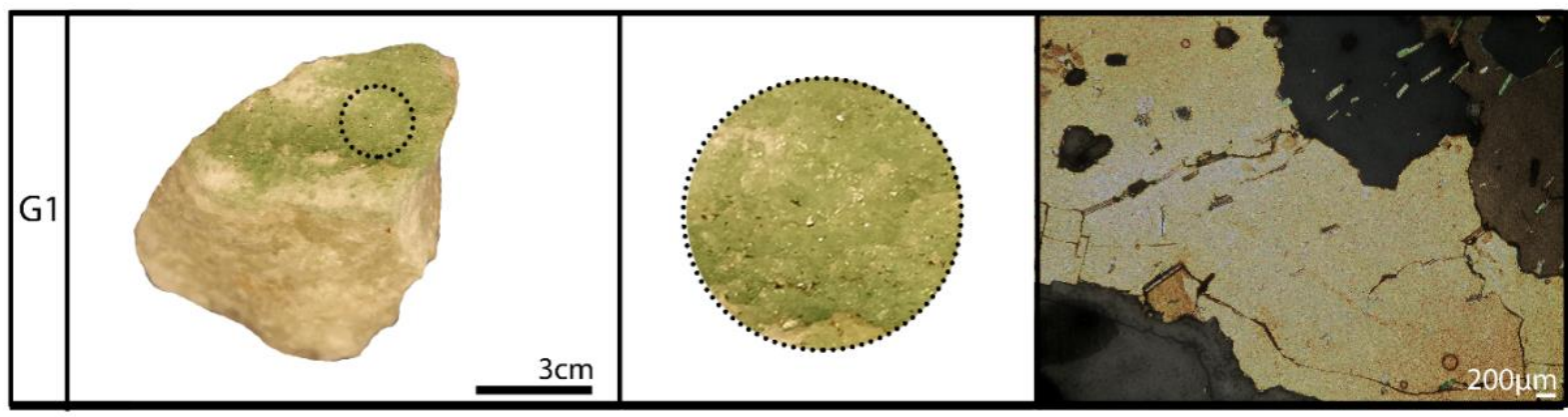

Fig. 6. Green Quartzites (RMG G1): Macroscopic textures and photomicrographs under crosselements, the quartzites from the five sampled outcrops present different yet complex geochemical fingerprints (Supplementary Materials Fig. 1). The major and trace element concentrations per sample (Table 5; Supplementary Materials Table 4), and the relative standard deviations (RSD\%) 315 indicate that samples from Endonyo Osunyai show high variability in $\mathrm{SiO}_{2}, \mathrm{Al}_{2} \mathrm{O}_{3}, \mathrm{~K}_{2} \mathrm{O}, \mathrm{Rb}, \mathrm{Ba}$, $316 \mathrm{~Pb}$, and Th (Supplementary Materials Fig. 2). Samples from Naibor Soit Kubwa show high 317 variability in $\mathrm{SiO}_{2}, \mathrm{MgO}, \mathrm{Y}, \mathrm{Ba}, \mathrm{Cu}$, and Th (Supplementary Materials Fig. 3). Samples from 318 Naibor Soit Ndogo show high variability in $\mathrm{SiO}_{2}, \mathrm{MgO}, \mathrm{Cu}$, Y, and $\mathrm{Ba}$ (Supplementary Materials 
319 Fig. 4). However, one outlier from Naibor Soit Ndogo has an unusually low $\mathrm{SiO}_{2}$ value for 320 quartzite (Supplementary Materials Table 4) which may be explained by spectra diffracted from a

321 large non-quartz crystal, given the reanalysis of the sample proportionate higher values for the $322 \mathrm{SiO} 2$ content. Samples from Naisiusiu show high variability in $\mathrm{SiO}_{2}, \mathrm{MgO}, \mathrm{Cu}$, and $\mathrm{Y}$ 323 (Supplementary Materials Fig. 5). Samples from Oittii show a high dispersion in $\mathrm{SiO}_{2}, \mathrm{Al}_{2} \mathrm{O}_{3}$, $324 \mathrm{~K}_{2} \mathrm{O}, \mathrm{Rb}$, and $\mathrm{Ba}$ (Supplementary Materials Fig. 6). The ratio between the maximum and minimum concentration of an element reflects the 326 variability among samples and outcrops. This variation indicates the complexity of the 327 geochemical profiles and the basement geology.

Linear correlations among the geochemical data from all samples were performed to 329 understand their relationships and identify regional patterns. The analysis indicates a slightly 330 significant negative correlation $\left[\mathrm{p}\right.$ (uncorr.) $<0.05$ ] among $\mathrm{SiO}_{2}$ some trace elements as $\mathrm{Rb}(\tau=$ $331-0.23), \mathrm{Sr}(\tau=-0.26), \mathrm{Ba}(\tau=-0.24)$ and $\mathrm{Th}(\tau=-0.22)$ (Fig. 7a), indicating the role of these 332 elements in the composition despite the major $\mathrm{SiO} 2$ presence on the samles.As for other major 333 oxides, they show significant positive correlations [p (uncorr.) $\leq 0.001]$ with most of the analyzed 334 trace elements, except for Y (Fig. 7a). Trace elements show positive correlations with different 335 degrees of significance among most other elements, apart from $\mathrm{MgO}$ which are not significant, 336 except for $\mathrm{Cu}, \mathrm{Y}$ and $\mathrm{Zr}[\mathrm{p}$ (uncorr.) $\leq$ 0.001] (Supplementary Materials Tables 5 and 6). 


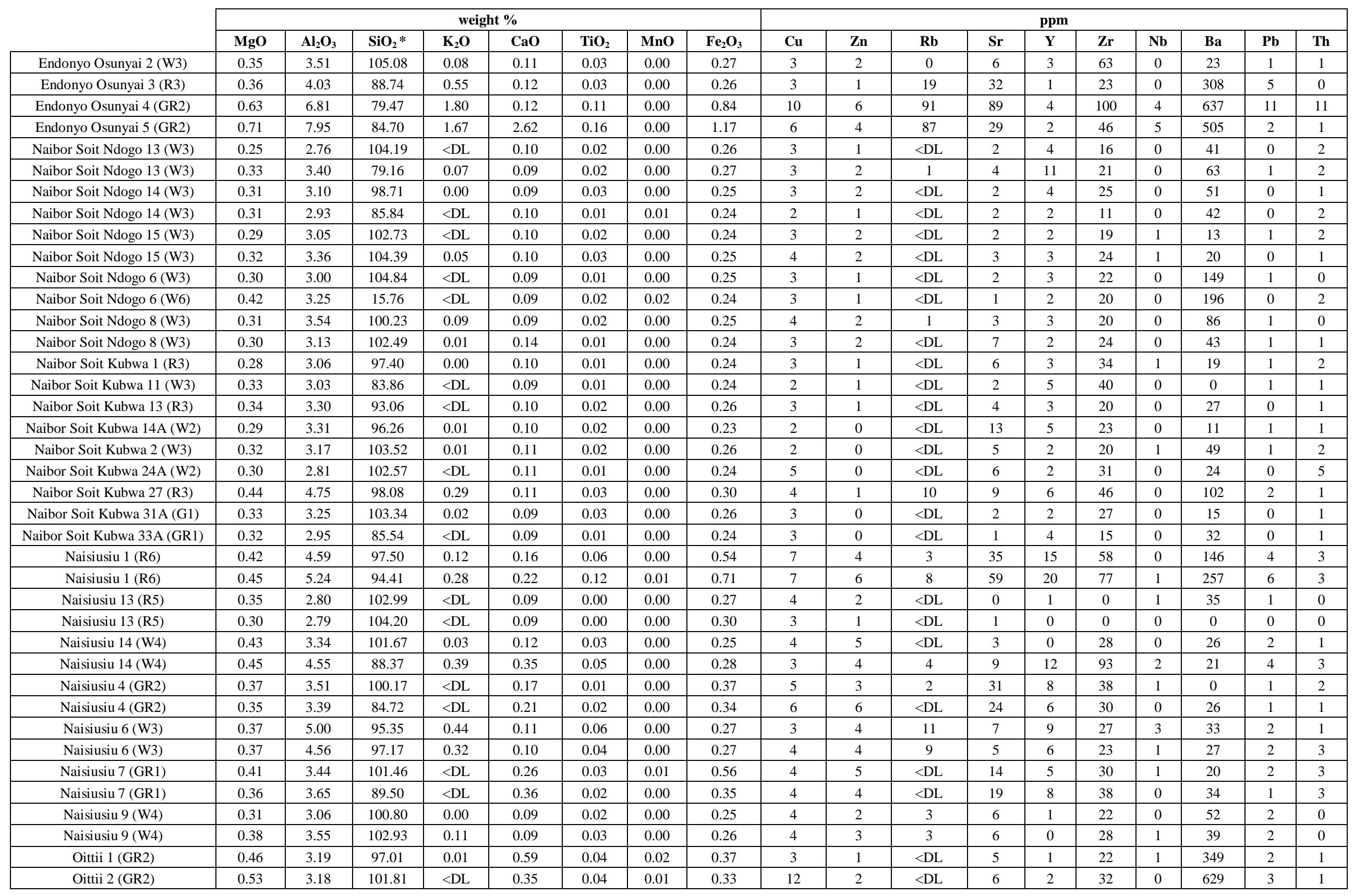




\begin{tabular}{|c|c|c|c|c|c|c|c|c|c|c|c|c|c|c|c|c|c|c|}
\hline & \multicolumn{8}{|c|}{ weight $\%$} & \multicolumn{10}{|c|}{ ppm } \\
\hline & MgO & $\mathbf{A l}_{2} \mathrm{O}_{3}$ & $\mathrm{SiO}_{2} *$ & $\mathrm{~K}_{2} \mathrm{O}$ & $\mathrm{CaO}$ & $\mathrm{TiO}_{2}$ & MnO & $\mathrm{Fe}_{2} \mathrm{O}_{3}$ & $\mathbf{C u}$ & Zn & $\mathbf{R b}$ & $\mathbf{S r}$ & $\mathbf{Y}$ & $\mathbf{Z r}$ & $\mathbf{N b}$ & $\mathbf{B a}$ & $\mathbf{P b}$ & Th \\
\hline Oittii 3 (W4) & 0.43 & 5.20 & 92.79 & 0.91 & 0.11 & 0.05 & 0.00 & 0.29 & 3 & 2 & 45 & 20 & 2 & 54 & 1 & 371 & 3 & 3 \\
\hline Oittii 4 (GR2) & 0.39 & 4.27 & 98.73 & 0.66 & 0.10 & 0.04 & 0.00 & 0.33 & 6 & 2 & 23 & 24 & 1 & 39 & 1 & 227 & 3 & 1 \\
\hline Oittii 5 (GR2) & 0.50 & 6.34 & 94.14 & 1.23 & 0.10 & 0.09 & 0.00 & 0.85 & 4 & 4 & 63 & 42 & 3 & 44 & 2 & 319 & 3 & 4 \\
\hline RGM-2 (Standard) & 0.27 & 13.36 & 74.07 & 3.36 & 0.95 & 0.30 & 0.04 & 1.84 & 11 & 30 & 146 & 106 & 23 & 226 & 8 & 845 & 20 & 14 \\
\hline RGM-2 (Standard) & 0.25 & 13.41 & 74.36 & 3.38 & 0.95 & 0.29 & 0.04 & 1.83 & 12 & 33 & 144 & 104 & 24 & 225 & 10 & 831 & 20 & 14 \\
\hline RGM-2 (Standard) & 0.25 & 13.46 & 74.60 & 3.38 & 0.95 & 0.29 & 0.04 & 1.85 & 10 & 30 & 145 & 107 & 26 & 228 & 9 & 838 & 20 & 14 \\
\hline RGM-2 (Standard; RV) & $\begin{array}{c}0.28 \\
\pm 0.02 \\
\end{array}$ & $\begin{array}{c}14 \\
\pm 0.02 \\
\end{array}$ & $\begin{array}{c}73.4 \\
\pm 0.41 \\
\end{array}$ & $\begin{array}{c}4.35 \\
\pm 0.16 \\
\end{array}$ & $\begin{array}{c}1.23 \\
\pm 0.16 \\
\end{array}$ & $\begin{array}{c}0.25 \\
\pm 0.02 \\
\end{array}$ & & $\begin{array}{c}1.86 \\
\pm 0.04 \\
\end{array}$ & $\begin{array}{c}9.8 \\
\pm 0.8 \\
\end{array}$ & $33 \pm 2$ & $147 \pm 5$ & $\begin{array}{r}108 \\
\pm 5 \\
\end{array}$ & $\begin{array}{l}24 \\
\pm 2\end{array}$ & $\begin{array}{l}222 \\
\pm 17 \\
\end{array}$ & 9.0 & $\begin{array}{l}842 \\
\pm 35 \\
\end{array}$ & $\begin{array}{r}20 \\
\pm 1 \\
\end{array}$ & $\begin{array}{l}15 \\
\pm 1 \\
\end{array}$ \\
\hline
\end{tabular}

Table 5. Raw EDXRF data per sample (major oxides: weight \%; trace elements: ppm) (<DL: values below detection limit) (RV: Recommended Value).

* Some $\mathrm{SiO}_{2}$ values are off the upper end of the calibration standard. 
The grouping of samples by outcrop reduces the linear correlations compared with ungrouped samples. Samples from Endonyo Osunyai (Fig. 7b) show significant negative correlations among among $\mathrm{SiO}_{2}$ and $\mathrm{K}_{2} \mathrm{O}, \mathrm{Rb}$ and $\mathrm{Ba}[\tau=-1 ; \mathrm{p}$ (uncorr.) $<0.05$ ), and positive ones $\left[\tau=1 ; \mathrm{p}\right.$ (uncorr.) $<0.05$ ] between $\mathrm{TiO} 2$ and $\mathrm{MnO}$, among $\mathrm{Al}_{2} \mathrm{O}_{3}$ and $\mathrm{MgO}$ and $\mathrm{CaO}$, and between $\mathrm{MgO}$ and $\mathrm{CaO}$ (Supplementary Materials Table 7). These major oxides together with $\mathrm{K} 2 \mathrm{O}$ present 344 significant positive correlations $[\tau=-1$; $\mathrm{p}$ (uncorr.) $<0.05]$, with some trace elements as $\mathrm{Rb}, \mathrm{Nb}$ 345 or Ba. When existing correlations among the analyzed trace elements they are positive and 346 significants. However, must to be considered that all these correlations stop being significants [p 347 (uncorr.) > 0.05] when applying the Monte Carlo simulation (Supplementary Materials Table 8). Most of the major oxides from Naibor Soit Kubwa are positively correlated (p (uncorr.) <0.05), among them and with some of the trace elements as $\mathrm{Cu}, \mathrm{Sr}, \mathrm{Nb}, \mathrm{Ba}$ and $\mathrm{Pb}$, with different degrees of significance (Fig. 7c) (Supplementary Materials Table 9). Only MnO and MgO present slight negative correlations with Th $[\tau=-0.67$; $\mathrm{p}$ (uncorr.) 0.01 , and -0.59 ; $\mathrm{p}$ (uncorr.) $=0.02$, respectively]. Regarding the trace elements, when existing signiticant correlations they are always positive (Fig. 7c). Most of these correlations are still significant [p (uncorr.) < 0.05] after applying the Monte Carlo simulation (Supplementary Materials Table 10). Samples from Naibor Soit Ndogo have few significant correlations. $\mathrm{SiO}_{2}$ shows a negative correlation with $\mathrm{MgO}[\tau=-0.52 ; \mathrm{p}$

356 (uncorr.) $<0.05]$, and $\mathrm{MgO}$ with $\mathrm{CaO}\left[\tau=-0.8 ; \mathrm{p}\right.$ (uncorr.)=0.00], While $\mathrm{K}_{2} \mathrm{O}$ presents positive 357 correlations of different degrees of significance $\left[\mathrm{p}\right.$ (uncorr.) $<0.05$ ] with $\mathrm{TiO}_{2}(\tau=0.50)$ and $\mathrm{Al}_{2} \mathrm{O}_{3}$ $358(\tau=0.8)($ Fig. 7d) (Supplementary Materials Table 11). Regarding the trace elements, only MnO 359 presents a negative correlation $[\mathrm{p}$ (uncorr. $)<0.05]$ with $\mathrm{Cu}(\tau=-0.57)$ and $\mathrm{Sr}(\tau=-0.8)$, and $\mathrm{Nb}$ 360 with $\mathrm{Ba}(\tau=-0.55)$. The rest of significant correlations among these are positive, and tend to 
361 maintain its significance after performing the Monte Carlo simulation (Supplementary Materials 362 Table 12). Samples from Naisiusiu show significant negative correlations [p (uncorr.) < 0.05] among $364 \mathrm{SiO}_{2}$ and $\mathrm{Al}_{2} \mathrm{O}_{3}(\tau=-0.45), \mathrm{CaO}(\tau=-0.44), \mathrm{Rb}(\tau=-0.39), \mathrm{Sr}(\tau=-0.46), \mathrm{Y}(\tau=-0.53), \mathrm{Zr}(\tau=-$ 365 0.44), and Th $(\tau=-0.41)$. The rest of major oxides are positively correlated among them with the 366 exception of $\mathrm{MnO}$ [p (uncorr.) > 0.05] (Fig. 7e) (Supplementary Materials Table 13). Trace 367 elements present in the Naisiusiu samples show some positive significant correlations [p (uncorr.) $368<0.05]$ with all the major elements, except for $\mathrm{SiO}_{2}$. Most of these correlations remain significant 369 after the Monte Carlo simulation (Supplementary Materials Table 14) Samples from Oittii show 370 positive significant correlationsamong $\mathrm{Al}_{2} \mathrm{O}_{3}, \mathrm{TiO}_{2}$ and $\mathrm{K} 2 \mathrm{O}, \mathrm{CaO}$ and $\mathrm{MnO}$ ), and $\mathrm{TiO}_{2}$ and $\mathrm{K}_{2} \mathrm{O}$ 371 (Fig. 7f) (Supplementary Materials Table 15). As for trace elements, when significant linear 372 correlations are detected, 


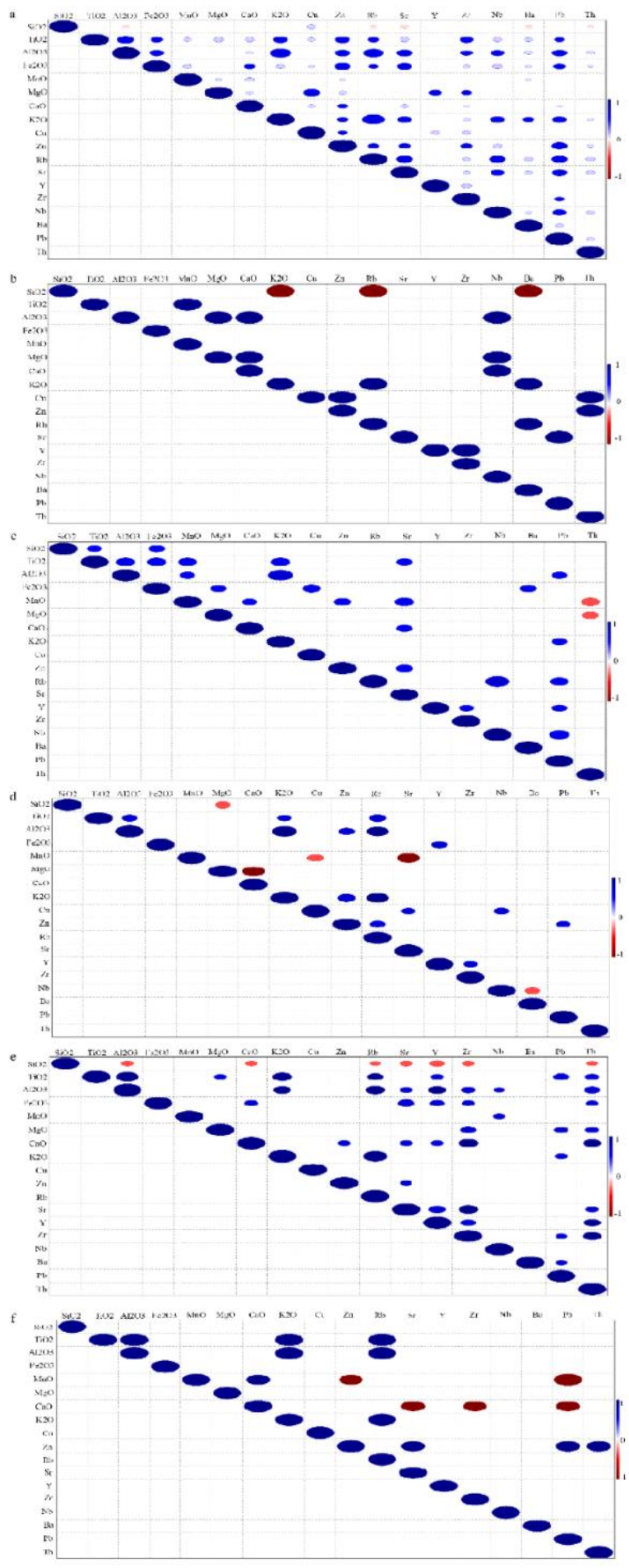

374 Fig. 7. Plot of significant correlations (Kendall's Tau) (positive: blue; negative: red). a) All 375 samples; b) Endonyo Osunyai; c) Naibor Soit Kubwa; d) Naibor Soit Ndogo; e) Naisiusiu; f) Oittii. $376 \quad$ 2-column fitting image. 
377 these are positive, apart from $\mathrm{CaO}$ and $\mathrm{Sr}, \mathrm{Zr}), \mathrm{Pb}(\tau=-0.84), \mathrm{MnO}$ and $\mathrm{Zn}(\tau=-0.84)$, and $\mathrm{Pb}(\tau$ $378=-1)$. However, these are not significant after applying the Monte Carlo simulation 379 (Supplementary Materials Table 16).

380 Variance analysis (Kruskal-Wallis test) on all samples grouped by outcrop allowed us to determine 381 the elemental variability among samples. When comparing all samples, the Kruskal-Wallis test 382 results in a $\mathrm{p}$ (same) $=<0.001$.. Samples from from Naibor Soit Ndogo [p(same) $=0.99]$ and Oitti $383[\mathrm{p}($ same $)=0.37] \mathrm{i}$ are the most homogeneous among the analyzed samples. Quartzites from Naibor 384 Soit Kubwa [p (same) $=<0.0001]$, Naisiusiu [p (same) $=0.0001]$, and Oittii [p (same) $<0.0001]$ 385 show variable intra-outcrop geochemical fingerprints. Further data exploration rejects the 386 hypothesis that variance is related with differential sample size per outcrop or by RMG. Plotting 387 the average of the Coefficient of Variation $(\mathrm{CV}=\mu / \sigma)$ for each outcrop against the number of 388 samples indicates an absence of correlation $[\mathrm{r}=0.09 ; \mathrm{p}$ (uncorr.) $=0.88]\left(\mathrm{r}^{2}=0.01\right)$. This is also 389 the case when plotting the average $\mathrm{CV}$ for each RMG against the number samples $[\mathrm{r}=0.44 ; \mathrm{p}$ $390 \quad$ (uncorr.) $=0.32]\left(\mathrm{r}^{2}=0.19\right)($ Fig. 8).

a)

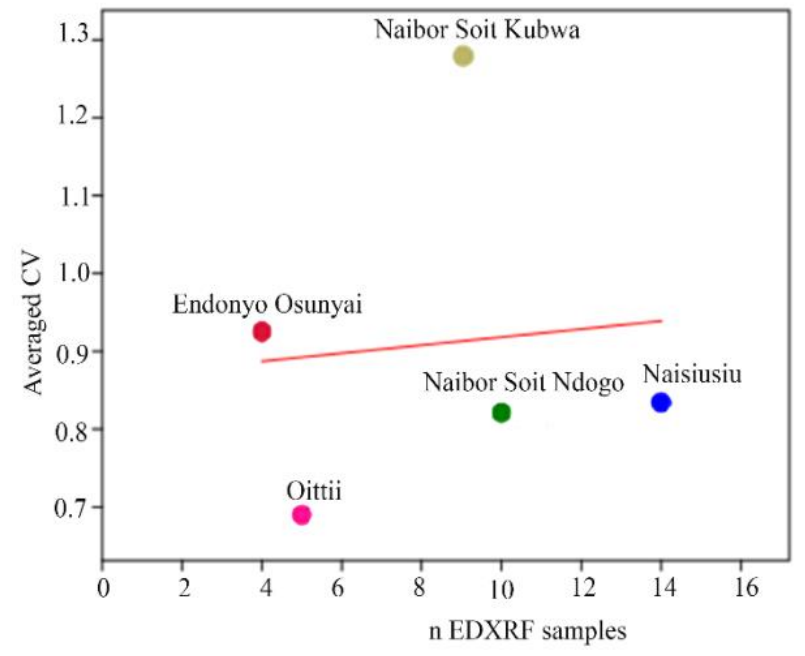

b)

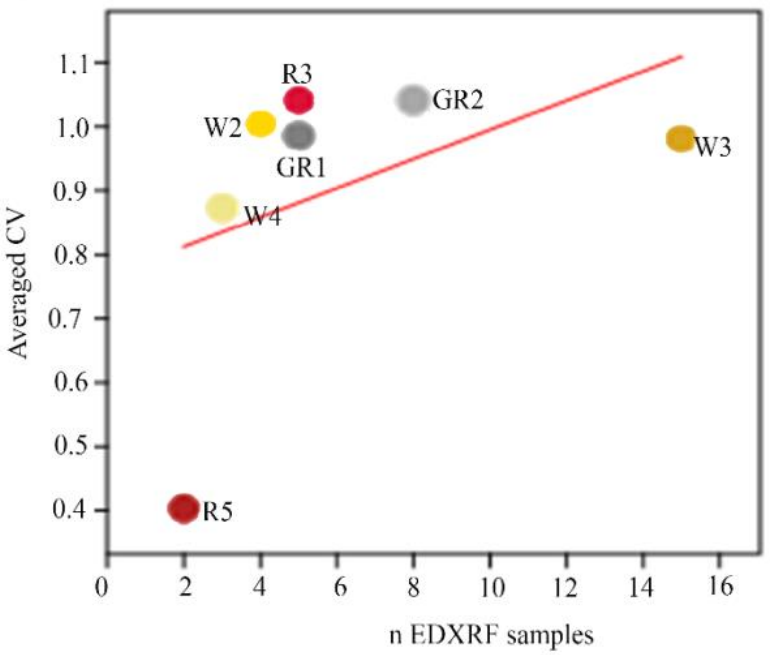


Fig. 8. a) Plot of the averaged CV against the number of EDXRF samples by outcrop; b) 393 Plot of the averaged CV against the number of EDXRF samples by RMG. 2-column fitting image.PCA $(\mathrm{KMO}=0.78)$ allowed us to explicate that the first three components retained $80.06 \%$ 395 of the cumulative variance (Table 6), confirming the segregative power of the geochemical data according to multivariate analysis. The first component is based on $\mathrm{Ba}, \mathrm{SiO}_{2}, \mathrm{Rb}, \mathrm{K} 2 \mathrm{O}, \mathrm{Th}, \mathrm{Pb}$, 397 and $\mathrm{Al}_{2} \mathrm{O}_{3}$ (eigenvector loadings range from 15-5\%), the second component is mainly based on $398 \mathrm{SiO}_{2}$ (eigenvector loading $>60 \%$ ) and $\mathrm{MgO}$ (eigenvector loading $\sim 25 \%$ ), and the third component 399 is based on $\mathrm{Y}, \mathrm{MgO}, \mathrm{Cu}$, and $\mathrm{SiO}_{2}$ (eigenvector loadings range from 40\%- 10\%) (Supplementary 400 Materials Fig. 7). According to these components, there is a high degree of correlation among the 401 geochemical composition of Naibor Soit Ndogo and Naisiusiu, despite their different averaged 402 geochemical profiles (Supplementary Materials Fig. 1), due to their elevated $\mathrm{SiO}_{2}$ and $\mathrm{MgO}$ 403 values. Quartzites from Endonyo Osunyai and Oittii also share similar geochemical fingerprints 404 based on the rest of the major and trace element values. Most samples from Naibor Soit Kubwa 405 are distinguishable from the other sampled outcrops, and have the most balanced elemental 406 compositions (Fig. 9).

The first three components of the DFA result in a cumulative variance of $98.61 \%$ (Table 408 7), confirming the discriminatory power of the geochemical data. The first component is mainly 409 determined by the presence of $\mathrm{MgO}, \mathrm{Y}, \mathrm{SiO}_{2}$, and $\mathrm{Cu}$. The second component is based on most of 410 the trace elements and major oxides. The third component is determined by the presence of $\mathrm{SiO}_{2}$ 411 and $\mathrm{MnO}$. According to these components, the geochemical profiles of the five analyzed outcrops 412 are different enough to be distinguishable, and only Naibor Soit Ndogo and Naisiusiu present some 413 similarities based on their $\mathrm{SiO}_{2}$ and $\mathrm{MgO}$ values (Fig. 10). DFA indicate that the 97.62\% samples 414 are correctly classified according their original provenance, and only one sample from Naibor Soit 
415 Ndogo has a geochemical profile that could be associated to Naisiusiu. $71.43 \%$ of the samples are

416 correctly classified using the Jackknife method, confirming the high significance of the

417 discriminant values for Naibor Soit Kubwa and Oittii (Supplementary Materials Table 17 and 18).

\begin{tabular}{|l|l|l|l|}
\hline $\begin{array}{c}\text { Principal } \\
\text { Component }\end{array}$ & Eigenvalue & \multicolumn{1}{|c|}{$\begin{array}{c}\text { Variance } \\
\text { Percentage }\end{array}$} & $\begin{array}{c}\text { Cumulative Variance } \\
\text { Percentage }\end{array}$ \\
\hline Dim. 1 & 1.562 & 52.630 & 52.630 \\
\hline Dim. 2 & 0.456 & 15.353 & 67.983 \\
\hline Dim. 3 & 0.358 & 12.073 & 80.056 \\
\hline Dim. 4 & 0.209 & 7.037 & 87.093 \\
\hline Dim. 5 & 0.148 & 4.985 & 92.078 \\
\hline Dim. 6 & 0.112 & 3.756 & 95.835 \\
\hline Dim. 7 & 0.043 & 1.452 & 97.286 \\
\hline Dim. 8 & 0.035 & 1.187 & 98.474 \\
\hline Dim. 9 & 0.028 & 0.936 & 99.410 \\
\hline Dim. 10 & 0.009 & 0.308 & 99.718 \\
\hline
\end{tabular}

418 Table 6. Eigenvalues and variance percentages of the PCA components. 

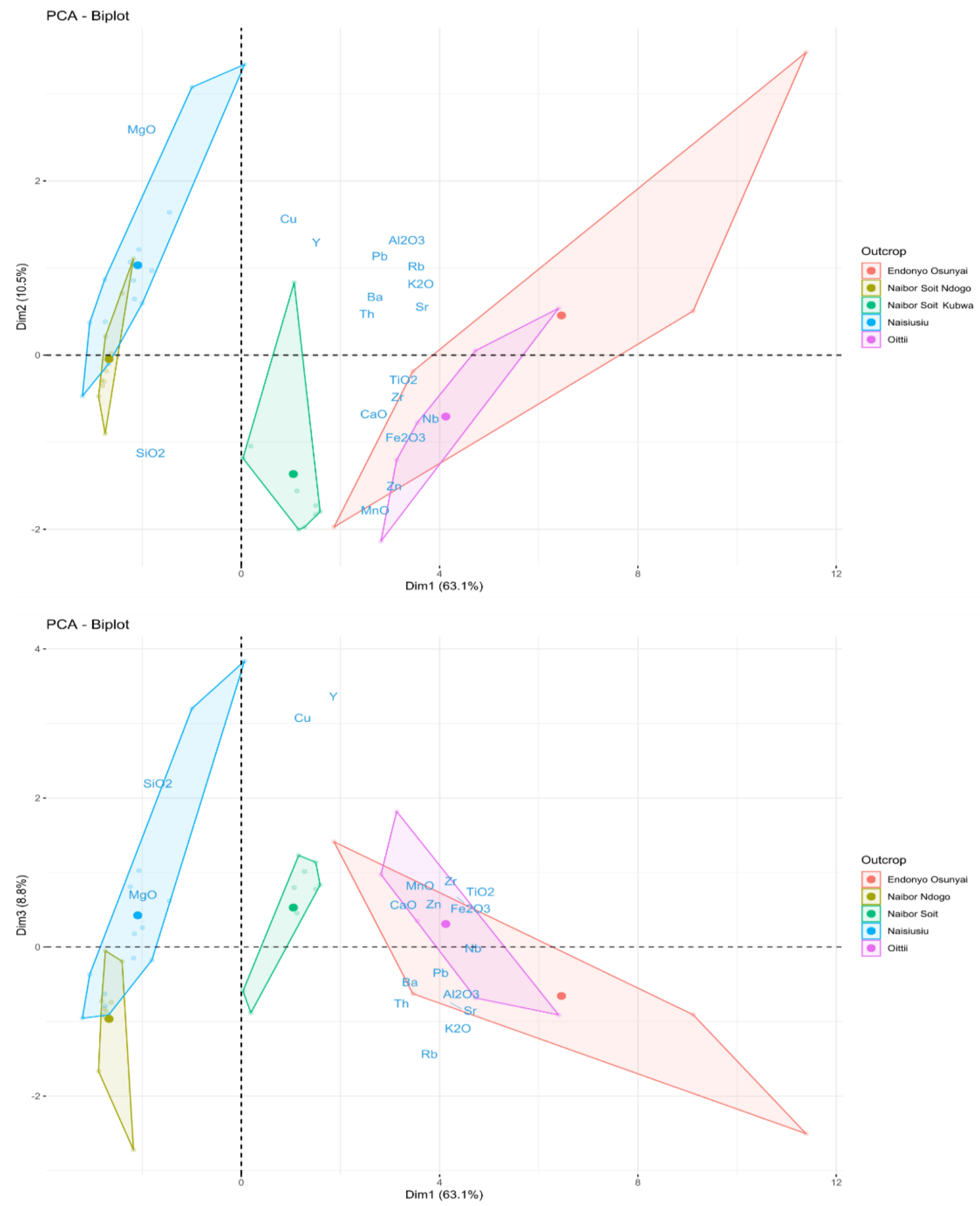

Fig. 9. PCA using EDXRF data with samples grouped by outcrop, including the variables

421 determining the first three components. 2-column fitting image. 

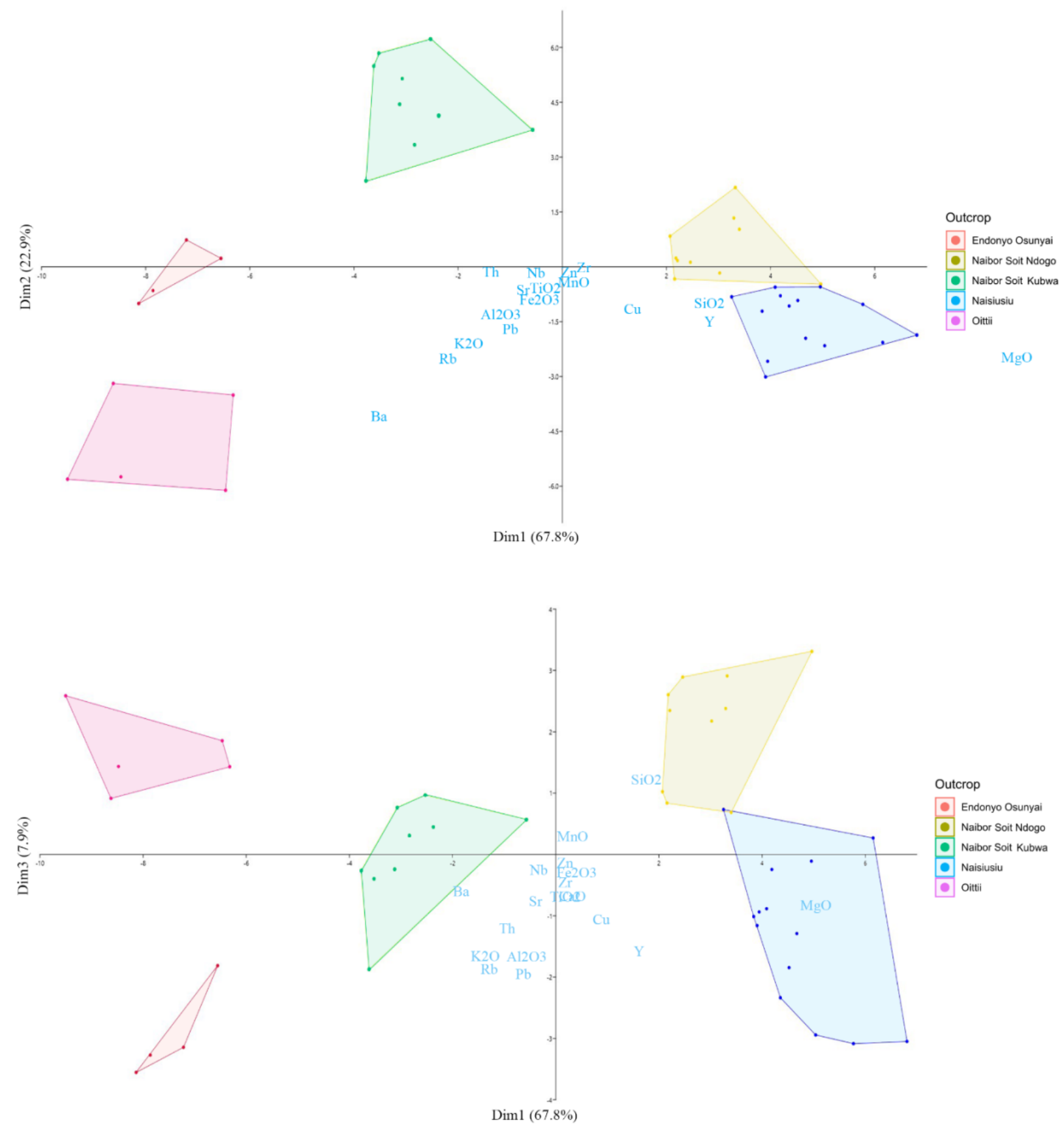

422

423 Fig.10. DFA using EDXRF data with samples grouped by outcrop, including the variables

424 determining the first three components. 2-column fitting image.

425 


\begin{tabular}{|l|l|l|l|}
\hline \multicolumn{1}{|c|}{$\begin{array}{c}\text { Principal } \\
\text { Component }\end{array}$} & Eigenvalue & $\begin{array}{c}\text { Variance } \\
\text { Percentage }\end{array}$ & $\begin{array}{c}\text { Cumulative Variance } \\
\text { Percentage }\end{array}$ \\
\hline Dim. 1 & 26.88 & 67.82 & 67.82 \\
\hline Dim. 2 & 9.07 & 22.89 & 90.71 \\
\hline Dim. 3 & 3.13 & 7.90 & 98.61 \\
\hline Dim. 4 & 0.55 & 1.38 & 100 \\
\hline
\end{tabular}

Table 7. Eigenvalues and variance percentages of the DFA components

\section{Discussion}

\subsection{Quartzite Fingerprints}

The macroscopic characteristics used to classify samples into RMGs were treated as independent variables in a second PCA (Fig. 11), which relied on the same cumulative variance and components as in the first PCA (Fig. 9). This was done to determine the comparability of macroscopic, petrographic, and geochemical approaches.

Red quartzite varieties (R1-R5) can be found at Endonyo Osunyai, Naibor Soit Kubwa, Naibor Soit Ndogo, and Naisiusiu. These range in texture from fine- to very coarse-grained, and predominantly consist of quartz along with lesser amounts of muscovite, hematite, rutile, and biotite. R3 consists of fine- to coarse-grained red quartzites from Endonyo Osunyai, Naibor Soit Kubwa, and Naibor Soit Ndogo, although these have distinguishable geochemical profiles. Biotitebearing quartzites (R5) are exclusive to Naisiusiu.

White quartzite varieties (W1-W4) can be found at all five sampled outcrops. These varieties range in texture from medium- to very coarse-grained, and predominantly consist of quartz along with minor amounts of muscovite, opaque minerals, hematite, and rutile. Very coarsegrained rutile-bearing quartzite (W2) is exclusive to Naibor Soit Kubwa and Naibor Soit Ndogo. However, differences in $\mathrm{SiO}_{2}$ values and trace elements for Naibor Soit Kubwa, and $\mathrm{MgO}$ for Naibor Soit Ndogo, allow us to distinguish among the quartzites from these two outcrops. RMGs W3 and W4 can be found at Endonyo Osunyai, Oittii, Naibor Soit Kubwa, Naibor Soit Ndogo, 
446 and Naisiusiu. However, samples classified in both varieties from Endonyo Osunyai, Oittii, and

447 Naibor Soit Kubwa are distinguishable to those from Naibor Soit Ndogo and Naisiusiu based on $448 \quad \mathrm{MgO}$ and $\mathrm{SiO}_{2}$ values.

449 Medium- to coarse-grained gray quartzites (GR1) can be found at Naibor Soit Kubwa, 450 Naibor Soit Ndogo, and Naisiusiu. Samples classified in GR1 from Naibor Soit Kubwa are 451 distinguishable from those of Naibor Soit Ndogo and Naisiusiu based on major and trace elements. 452 However, Naibor Soit Ndogo and Naisiusiu have similar geochemical profiles. Fine- to medium453 grained gray quartzites (GR2) can be found at Endonyo Osunyai, Oittii, and Naisiusiu. While GR2 454 quartzites from the former two outcrops have similar geochemical fingerprints, they can be 455 distinguished to those from Naisiusiu based on differences in $\mathrm{MgO}$ values.

456 Green fuchsite-bearing quartzite $(\mathrm{G} 1)$ is exclusively found at Naibor Soit Kubwa and 457 Naibor Soit Ndogo, affirming these inselbergs as the primary sources for this RMG.

458 The first three components of the DFA result in a cumulative variance of $87.28 \%$ (Table 459 7), confirming the discriminatory power of the geochemical data and the macroscopic 460 classification. The first component is mainly determined by the presence of $\mathrm{Y}, \mathrm{Ba}, \mathrm{Cu}, \mathrm{Pb}, \mathrm{Al}_{2} \mathrm{O}_{3}$, 461 and $\mathrm{MgO}$ The second component is based mostly on $\mathrm{Ba}, \mathrm{RB}, \mathrm{K} 2 \mathrm{O}$, and $\mathrm{Th}$. The third component 462 is mainly determined by the presence of trace elements such as Th, Y, and Sr along with major 463 oxides such as $\mathrm{Fe}_{2} \mathrm{O}_{3}$ or $\mathrm{Al}_{2} \mathrm{O}_{3}$. According to these components, the discrimination of samples 464 classified in RMGs R5, and GR2 is clear according to their geochemical compositions. However, 465 geochemical overlap exists among the RMGs W1-4, G1, and R3 due to their $\mathrm{SiO}_{2}$ contents (Fig. 466 12). 

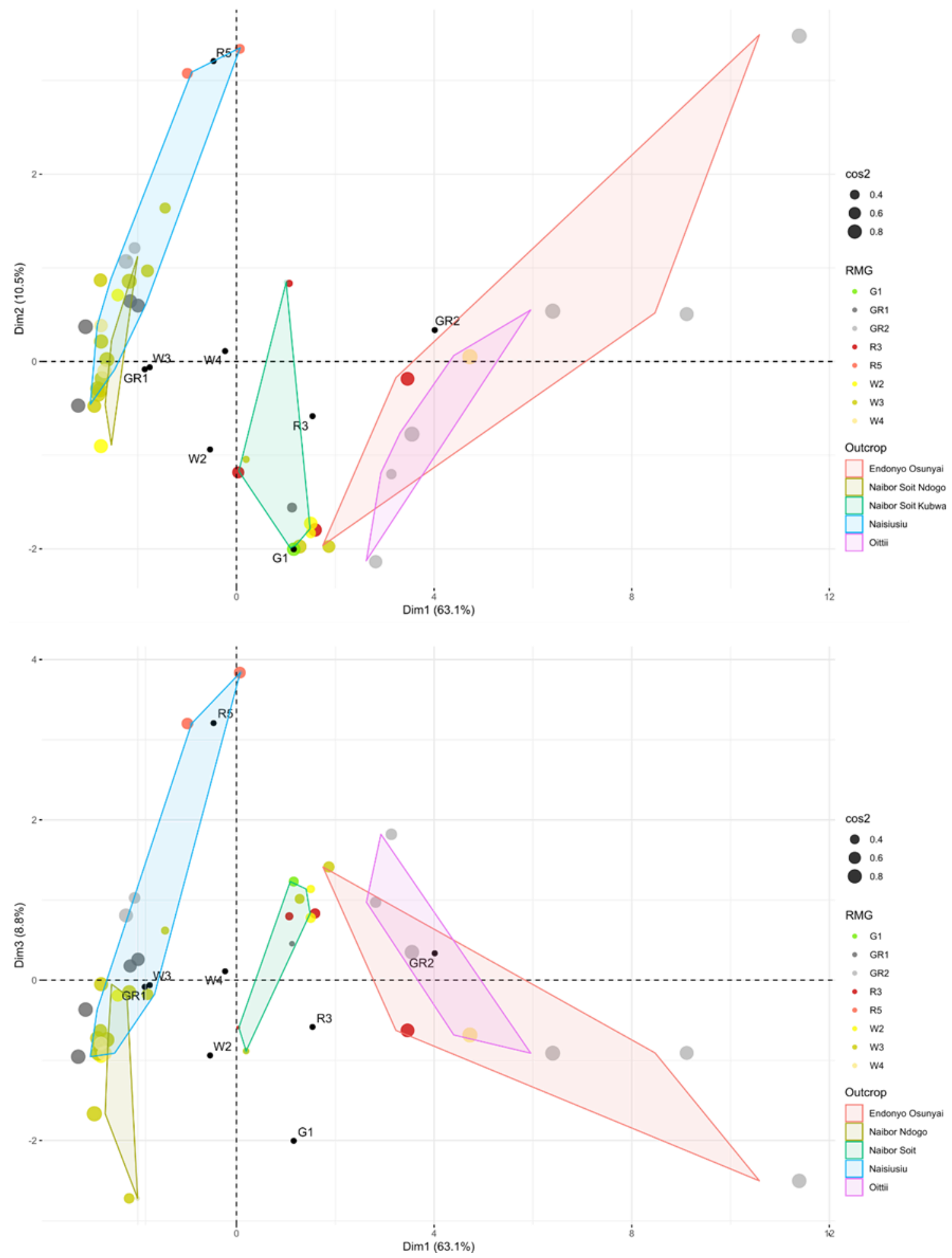

Fig. 11. PCA using EDXRF data with samples labelled by their RMG. Cumulative variance and components identical to those used in the first PCA (see Fig. 9). 2-column fitting image. 
470 Despite this overlap, the confusion matrix of the DFA indicates that $85.71 \%$ of the samples were

471 correctly classified, being extremely significant (100\%) in the case of RMGs GR1, R5, and W4.

$47240.48 \%$ of the samples are correctly classified using the Jackknife method, confirming the high

473 significance of the discriminant values for samples classified in RMG R5 (Supplementary

474 Materials Tables 19 and 20).

\begin{tabular}{|l|l|l|l|}
\hline \multicolumn{1}{|c|}{$\begin{array}{c}\text { Principal } \\
\text { Component }\end{array}$} & Eigenvalue & \multicolumn{1}{|c|}{$\begin{array}{c}\text { Variance } \\
\text { Percentage }\end{array}$} & \multicolumn{1}{c|}{$\begin{array}{c}\text { Cumulative Variance } \\
\text { Percentage }\end{array}$} \\
\hline Dim. 1 & 15.227 & 47.53 & 47.53 \\
\hline Dim. 2 & 10.017 & 31.27 & 78.8 \\
\hline Dim. 3 & 2.718 & 8.48 & 87.28 \\
\hline Dim. 4 & 1.954 & 1.38 & 93.38 \\
\hline
\end{tabular}

475 Table 7. Eigenvalues and variance percentages of the DFA components
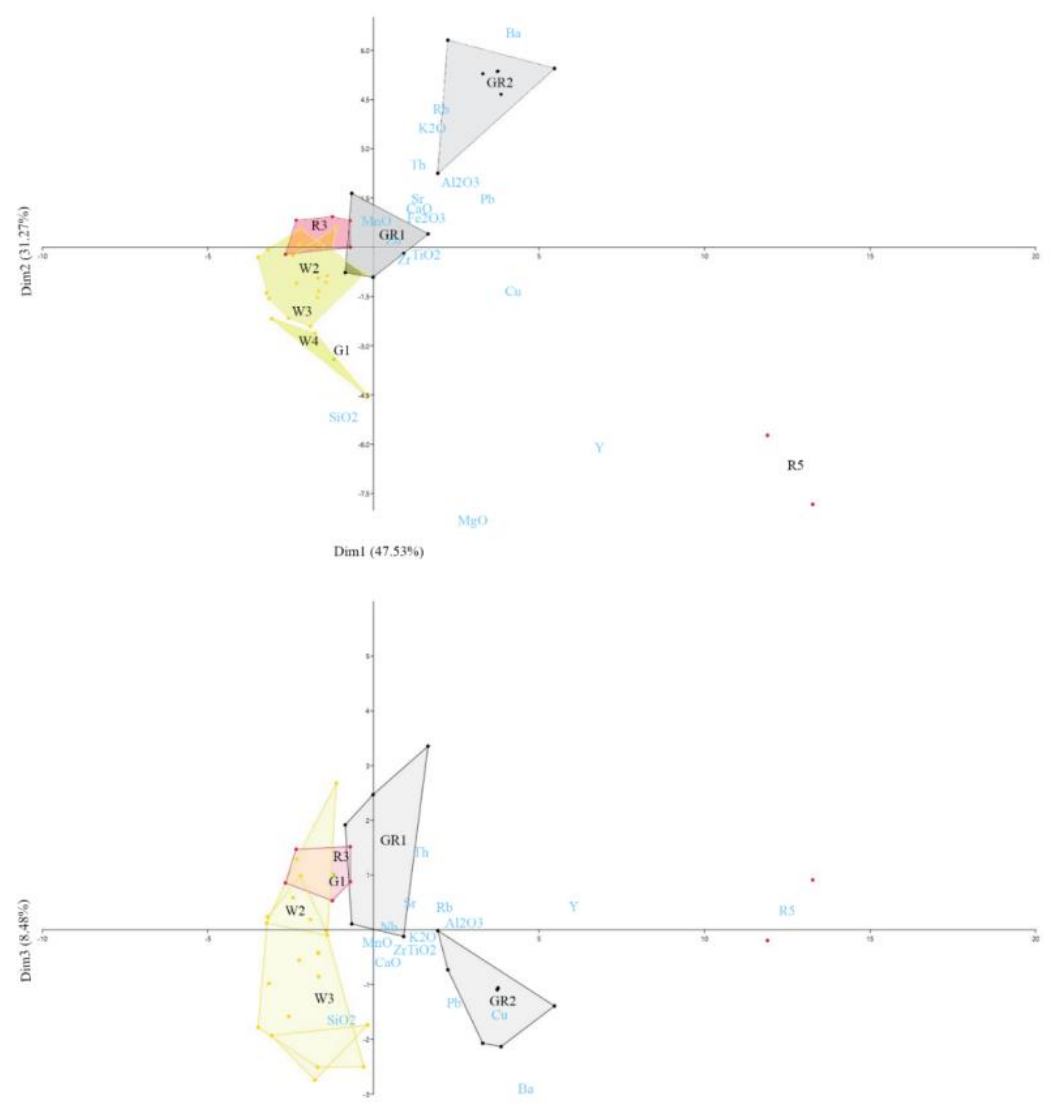
5.2. Fig. 12. DFA using EDXRF data with samples grouped by RMG, including the variables determining the first three components. 2-column fitting image. Multi-Scalar Approach Considering that quartz-rich rocks were widely exploited during the ESA throughout continental Africa (Braun et al., 2009; Bunn, 1982; Chavaillon, 1976; Chazan et al., 2012; Harris et al., 1987; Howell et al., 1987; Isaac and Harris, 1978; Kaufulu and Stern, 1987; Kuman, 1996; Kuman and Field, 2009; Kuman and Clarke, 2000; McNabb and Kuman, 2015; Merrick and Merrick, 1976; Plummer, 2004; Sheppard and Kleindienst, 1996; Toth, 1982), these rock types represent an important avenue to better understand early hominin technology and ecological behavior (Ambrose, 2001; Braun and Hovers, 2009; de Heinzlein et al., 1999; Potts, 1994; Schick, 1987). However, there are only a few ESA characterization studies specifically dealing with quartzite designed to establish its sourcing prospects, and most of these studies specifically deal with material from Oldupai Gorge (Blumenschine et al. 2008; Braun et al. 2008b; Hay, 1976; Kyara, 1999; McHenry and de la Torre, 2018; Tactikos, 2005). Despite this, most of these studies have been limited by small reference collections, with the clear exception of Braun et al. (2008b). While acknowledging the inherent limitations of lithic raw material studies, such as the possibility that there are unknown and/or unexposed outcrops (Santonja et al., 2014), the characterization of known outcrops is a necessary first step to determine resource availability and lithological diversity (e.g. Dibble, 1991; Féblot-Augustins, 1990, 1997; Shackley, 1998; Wilson, 2007; Wilson et al. 2018). Therefore, this study represents an effort to build upon prior studies at Oldupai using a multi-scalar fingerprinting approach to characterize reference materials from five known quartzitic outcrops.

Macroscopic properties reveal that quartzites from different sources are relatively homogenous in terms of their morphology. However, differences in color, grain size, texture, and 
500 mineral composition allowed us to identify twelve RMGs, some of them coincident with 501 macroscopic varieties previously described (McHenry and de la Torre, 2018) (Supplementary 502 Materials Table 1). Thin section petrographic analyses of twelve samples, one from each RMG, 503 reveal that quartzites are predominantly composed of quartz (85-98\%), along with varying modes 504 of muscovite (2-14\%), and other accessory minerals such as rutile $(<1-1 \%)$, biotite $(1 \%)$, and 505 fuchsite $(<1 \%)$. The presence of certain accessory minerals such as biotite and fuchsite 506 occasionally coincided with our macroscopic classifications of RMGs thereby opening the 507 possibility that stone tools may be sourced to specific outcrops based on mineralogy. Exploratory 508 testing of the geochemical data allowed us to identify the fingerprints of eight of the twelve RMGs 509 that may be useful for provenance studies. EDXRF results propose a high degree of heterogeneity 510 with significant differences at the intra- and inter-outcrop levels. Major elements (except $\mathrm{SiO}_{2}$ ), 511 and particularly trace elements, are helpful to differentiate between quartzites from Endonyo 512 Osunyai and Oittii, while high $\mathrm{MgO}$ values are associated with quartzites from Naibor Soit Ndogo 513 and Naisiusiu. Besides showing the highest intra-outcrop homogeneity, Naibor Soit Kubwa 514 quartzites have the highest $\mathrm{SiO}_{2}$ content, which may give this raw material ideal mechanical 515 properties for knapping stone tools. This could, at least partly, allow authors to propose that Naibor 516 Soit Kubwa may have been the principal source of quartzite for artifact manufacture in the eastern 517 Oldupai palaeobasin (Blumenschine et al., 2008 Santonja et al 2014; Tactikos 2005). Historically, macroscopic and petrographic techniques have been utilized for lithic sourcing 519 (Bond, 1948; Cogné and Giot, 1952; Keiller et al., 1941; Shotton and Hendry, 1979), although 520 geochemical techniques have been increasingly utilized since the 1960s, particularly for obsidian 521 (Cann and Renfrew, 1964; Heizer et al., 1965; Jack and Heizer, 1968; Parks and Tieh, 1966; 522 Weaver and Stross, 1965). In combining these techniques, our multi-scalar analysis reveals that 
523 most RMGs, defined based on macroscopic criteria, are ubiquitous at Oldupai Gorge, and can be

524 found at different outcrops (see Fig. 11). The petrographic data reveal that most quartzites are

525 mineralogically homogenous. However, certain accessory minerals are unique to some outcrops

526 and their presence correlates with two of our RMG classifications (see Table 4). Lastly, our

527 statistical analyses of the geochemical data show that there are elemental compositions

528 characteristic of certain outcrops, and these coincide with most of the macroscopic classifications

529 into RMGs. Altogether, the combination of techniques offers the strongest ability to differentiate

530 among quartzites from different outcrops at Oldupai that no singular technique alone accomplishes

531 on a satisfactory basis. Resource-bearing, we suggest that future provenance studies conduct

532 detailed multi-scalar analyses to shed light on each technique's analytical power, particularly for

533 rock types less amenable to geochemical sourcing alone (e.g. obsidian).

534 6. Conclusions

535 This study implemented a multi-scalar approach to systematically characterize the intra-

536 and inter-outcrop lithological variability of five quartzitic outcrops adjacent to Oldupai Gorge.

537 These outcrops were likely the primary sources for quartzitic raw materials and may have been of

538 high importance for early hominin technological organization and palaeoecological behavior. This

539 was accomplished by the macroscopic classification of geological samples into discrete RMGs, as

540 well as selective petrographic and EDXRF analyses.

541 Using a combination of destructive and non-destructive techniques, we identified twelve

542 RMGs that can be found at five quartzitic outcrops adjacent to Oldupai Gorge. Based on mineral 543 assemblages and modes, we conclude that at least three RMGs are exclusively found at specific 544 outcrops (R5: Naisiusiu; W2 and G1: Naibor Soit Kubwa and Naibor Soit Ndogo). Quartzites from 545 Naibor Soit Kubwa have a unique geochemical composition. Quartzites from Endonyo Osunyai, 
546 Oittii, Naibor Soit Ndogo, and Naisiusiu have overlapping bulk rock geochemistry but they can be

547 differentiated from each other using a combination of macroscopic, petrographic, and geochemical

548 data. Although additional research is required to establish stronger links between mineralogy and

549 geochemistry, the methodology outlined here and the promising results provide a stepping-stone

550 for future characterization studies and archaeological applications. It is hoped that our results

551 considered alongside other successful case studies (e.g. Blomme et al., 2012; Cnudde et al., 2013;

552 Dalpra and Pitblado, 2016; Pitblado et al., 2008, 2013; Veldeman et al., 2012) will spur other

553 researchers to determine the feasibility of differentiating quartzites and other quartz-rich

554 lithologies on regional scales. Such studies may come to yield surprising results and prove to be

555 of critical importance to further our understanding of hominin behavior, since quartz-rich raw

556 materials were widely exploited during the African ESA and thereafter in the archaeological 557 record. 


\section{Declarations of Interest}

None.

\section{Acknowledgements}

This work was supported by the Canadian Social Sciences and Humanities Research Council under its Partnership Grant Program no. 895-2016-1017. The Tanzania Commission for Science and Technology authorized this work under permit no. 2018-112-NA-2018-36. The Tanzanian Ministry of Natural Resources and Tourism, through its Antiquities Division, granted us permission to carry out this work (14/2017/2018) and authorities at the Ngorongoro Conservation Area allowed us to enter the protected area (BE.504/620/01/53). The export license for the materials presented in this study were obtained from the Antiquities Division (EA.150/297/01: 5/2018/2019) and the Tanzanian Executive Secretary from the Mining Commission (00001258). The McMaster Archaeological XRF Lab (directed by TC) was funded by the Canada Foundation for Innovation. The SDS project acknowledges the essential contributions by the Maasai communities at Oldupai Gorge concerning the knowledge presented herein. Authors acknowledge the editor and the anonymous reviewers for their suggestions and constructive comments that contributed to the improvement of the manuscript.

\section{Data Availability}

Datasets related to this manuscript are available at the Federated Research Data Repository (doi: http://dx.doi.org/10.20383/101.0150) and a preprint is available at the Open Science Framework (https://osf.io/qmxpy/).

\section{Funding}

This work was supported by the Canadian Social Sciences and Humanities Research Council under its Partnership Grant Program no. 895-2016-1017. 


\section{References}

Ambrose, S.H., 2001. Paleolithic technology and human evolution, Science 291, 17481753. 10.1126/science.1059487

Andrefsky, W., 2005. Lithics: Macroscopic Approaches to Analysis (Cambridge Manuals in Archaeology), Cambridge University Press Cambridge

Baker, B.H., Mohr, P.A., Williams, L.A.J., 1972. Geology of the eastern rift system of Africa, Geological Society of America.

Bamforth, D.B., 1990. Settlement, raw material, and lithic procurement in the central Mojave Desert, Journal of Anthropological Archaeology 9, 70-104. https://doi.org/10.1016/0278-4165(90)90006-Y

Binford, L.R., 1979. Organization and formation processes: looking at curated technologies, Journal of anthropological research 35, 255-273. https://doi.org/10.1086/jar.35.3.3629902

Binford, L.R., 1980. Willow smoke and dogs' tails: hunter-gatherer settlement systems and archaeological site formation, American antiquity 45, 4-20. https://doi.org/10.2307/279653 Macmillan.

Blatt, H., Tracy, R., Owens, B., 2006. Petrology: igneous, sedimentary, and metamorphic,

Blomme, A., Degryse, P., Van Peer, P., Elsen, J., 2012. The characterization of sedimentary quartzite artefacts from Mesolithic sites, Belgium. Geologica Belgica 15, 193-199. https://popups.uliege.be:443/1374-8505/index.php?id=3690

Blumenschine, R.J., Masao, F.T., Tactikos, J.C., Ebert, J.I., 2008. Effects of distance from stone source on landscape-scale variation in Oldowan artifact assemblages in the PaleoOldupai Basin, Tanzania, Journal of Archaeological Science 35, 76-86. https://doi.org/10.1016/j.jas.2007.02.009

Bond, G., 1948. Rhodesian Stone Age Man and His Raw Materials. The South African Archaeological Bulletin 3, 55-60. https://www.jstor.org/stable/3886949

Brantingham, P.J., 2003. A neutral model of stone raw material procurement, American Antiquity 68, 487-509. https://doi.org/10.2307/3557105

Braun, D.R., Hovers, E., 2009. Introduction: Current issues in Oldowan research, Interdisciplinary approaches to the Oldowan, Springer, pp. 1-14

Braun, D.R., Rogers, M.J., Harris, J.W., Walker, S.J., 2008a. Landscape-scale variation in hominin tool use: evidence from the developed Oldowan, Journal of Human Evolution 55, 1053-1063. https://doi.org/10.1016/j.jhevol.2008.05.020

Braun, D.R., Plummer, T., Ditchfield, P., Ferraro, J.V., Maina, D., Bishop, L.C., Potts, R., 2008b. Oldowan behavior and raw material transport: perspectives from the Kanjera Formation. Journal of Archaeological Science 35, 2329-2345. https://doi.org/10.1016/j.jas.2008.03.004

Braun, D.R., Plummer, T., Ferraro, J.V., Ditchfield, P., Bishop, L.C., 2009. Raw material quality and Oldowan hominin toolstone preferences: evidence from Kanjera South, Kenya, Journal of Archaeological Science 36, 1605-1614. https://doi.org/10.1016/j.jas.2009.03.025

Bunn, H., 1982. Meat-Eating and Human Evolution: Studies on the Diet and Subsistence Patterns of Plio-Pleistocene Hominids in East Africa, University of California, Berkley

Cann, J.R., Renfrew, C., 1964. The Characterization of Obsidian and its application to the Mediterranean Region. Proceedings of the Prehistoric Society 30, 111-133. https://doi.org/10.1017/S0079497X00015097 
Cahen, D., 1975. Le site archéologique de la Kamoa (région du Shaba, République du Zaïre) de l'âge de la pierre ancien à l'âge du fer. Tervuren: Musée Royal de l'Afrique Centrale.

Cahen, L., Snelling, N., 1966. The geochronology of equatorial Africa, North-Holland Publishing Company

Cahen, L., Snelling, N., Delhal, J., Vail, J., Bonhomme, M., Ledent, D., 1984. The geochronology and evolution of Africa.

Calogero, B.L., 1992. Lithic misidentification, Man in the Northeast 43, 87-90

Calogero, B.L., 1991. Macroscopic and petrographic identification of the rock types used for stone tools in central Connecticut, University of Connecticut

Carter, T., Shackley, M.S., 2007. Sourcing obsidian from Neolithic Çatalhöyük (Turkey) using energy dispersive X-ray fluorescence, Archaeometry 49, 437-454.

https://doi.org/10.1111/j.1475-4754.2007.00313.x

Chavaillon, J., 1976. Evidence for the technical practices of early pleistocene hominids, Shungura Formation, Lower Omo Valley, Ethiopia

Chazan, M., Avery, D.M., Bamford, M.K., Berna, F., Brink, J., Fernandez-Jalvo, Y., Goldberg, P., Holt, S., Matmon, A., Porat, N., 2012. The Oldowan horizon in Wonderwerk Cave (South Africa): Archaeological, geological, paleontological and paleoclimatic evidence, Journal of Human Evolution 63, 859-866. http://dx.doi.org/10.1016/j.jhevol.2012.08.008

Cnudde, V., Dewanckele, J., De Kock, T., Boone, M., Baele, J.-M., Crombé, P.,

Robinson, E., 2013. Preliminary structural and chemical study of two quartzite varieties from the same geological formation: a first step in the sourcing of quartzites utilized during the Mesolithic in northwest Europe. Geologica Belgica 16, 27-34. https://popups.uliege.be:443/13748505/index.php?id=3981

Cogné, J.E., Giot, P.-R., 1952. Étude pétrographique des haches polies de Bretagne. Bulletin de la Société préhistorique française 49, 388-395. https://doi.org/10.3406/bspf.1952.5080

Dalpra, C.L., Pitblado, B.L., 2016. Discriminating Quartzite Sources Petrographically in the Upper Gunnison Basin, Colorado: Implications for Paleoamerican Lithic-Procurement Studies. PaleoAmerica 2, 22-31. https://doi.org/10.1080/20555563.2015.1137684

Dawson, J., 1992. Neogene tectonics and volcanicity in the North Tanzania sector of the Gregory Rift Valley: contrasts with the Kenya sector, Tectonophysics 204, 81-92. https://doi.org/10.1016/0040-1951(92)90271-7

Dawson, J.B., 2008. The Gregory rift valley and Neogene-recent volcanoes of northern Tanzania, Geological Society of London

De Heinzelin, J., Clark, J.D., White, T., Hart, W., Renne, P., WoldeGabriel, G., Beyene, Y., Vrba, E., 1999. Environment and behavior of 2.5-million-year-old Bouri hominids, Science 284, 625-629.10.1126/science.284.5414.625

Delagnes, A., Roche, H., 2005. Late Pliocene hominid knapping skills: the case of Lokalalei 2C, West Turkana, Kenya, Journal of Human Evolution 48, 435-472.

https://doi.org/10.1016/j.jhevol.2004.12.005

Demars, P.Y., 1982. L'utilisation du silex au Paléolithique supérioir: chois, approvisionnment, circulation. L'exemple du bassin de Brive, Centre National de la Recherche Scientifique

Dibble, H.L., 1991. Local raw material exploitation and its effects on Lower and Middle Paleolithic assemblage variability, Raw material economies among prehistoric hunter-gatherers $19,33-47$ 
Féblot-Augustins, J., 1990. Exploitation des matières premières dans l'Acheuléen d'Afrique: perspectives comportementales, Paléo, Revue d'Archéologie Préhistorique 2, 27-42. https://doi.org/10.3406/pal.1990.987

Féblot-Augustins, J., 1997. Middle and Upper Palaeolithic raw material transfers in western and central Europe: assessing the pace of change, Journal of Middle Atlantic Archaeology 13, 57-90. 〈halshs-00436336〉

Folk, R.L., 1980. Petrology of sedimentary rocks, Hemphill Publishing Company.0914696149

Foster, A.N., Ebinger, C.J., Mbede, E., Rex, D., 1997. Tectonic development of the northern Tanzanian sector of the East Africa Rift System, Journal of the Geological Society of London

Frahm, E., 2014. Characterizing obsidian sources with portable XRF: accuracy, reproducibility, and field relationships in a case study from Armenia, Journal of Archaeological Science 49, 105-125. https://doi.org/10.1016/j.jas.2014.05.003

Freeman, L.G., 1994. Torralba and Ambrona: a review of discoveries, Integrative Paths to the Past, 597-638

Fritz, H., Abdelsalam, M., Ali, K., Bingen, B., Collins, A., Fowler, A., Ghebreab, W., Hauzenberger, C., Johnson, P., Kusky, T., 2013. Orogen styles in the East African Orogen: a review of the Neoproterozoic to Cambrian tectonic evolution, Journal of African Earth Sciences $86,65-106$

George, R., Rogers, N., Kelley, S., 1998. Earliest magmatism in Ethiopia: Evidence for two mantle plumes in one flood basalt province, Geology 26, 923-926. https://doi.org/10.1130/0091-7613(1998)026<0923:EMIEEF>2.3.CO;2

Glascock, M.D., Neff, H., 2003. Neutron activation analysis and provenance research in archaeology, Measurement Science and Technology 14, 1516.0957-0233/03/091516

Goldman-Neuman, T., Hovers, E., 2009. Methodological considerations in the study of Oldowan raw material selectivity: insights from AL 894 (Hadar, Ethiopia), Interdisciplinary approaches to the Oldowan, Springer, pp. 71-84

Goldman-Neuman, T., Hovers, E., 2012. Raw material selectivity in late Pliocene Oldowan sites in the Makaamitalu Basin, Hadar, Ethiopia, Journal of human evolution 62, 353366. https://doi.org/10.1016/j.jhevol.2011.05.006

Goodale, N., Andrefsky, W.e., 2015. Lithic technological systems and evolutionary theory, Cambrudge University Press, New York

Greenwood, S.M., 2014. Mineralogy and Geochemistry of Pleistocene Volcanics at Embagai Caldera and Natron Basin, Tanzania: Potential Constraints on the Stratigraphy of Oldupai Gorge, p. 497

Harris, J.W., Williamson, P.G., Verniers, J., Tappen, M.J., Stewart, K., Helgren, D., de Heinzelin, J., Boaz, N.T., Bellomo, R.V., 1987. Late Pliocene hominid occupation in Central Africa: the setting, context, and character of the Senga 5A site, Zaire, Journal of Human Evolution 16, 701-728. https://doi.org/10.1016/0047-2484(87)90020-0

Hay, R.L., 1976. Geology of the Oldupai gorge, University of California Press.5885053340

Hepworth, J.V., 1972. The Mozambique orogenic belt and its foreland in northeast Tanzania: a photogeologically-based study, Journal of the Geological Society 128, 461-494 
Heizer, R.F., Williams, H., Graham, J.A., 1965. Notes on Mesoamerican Obsidians and Their Significance in Archaeological Studies. Contributions of the University of California Archaeological Research Facility 1, 94-103.

Hermes, O.D., Luedtke, B.E., Ritchie, D., 2001. Melrose green rhyolite: its geologic setting and petrographic and geochemical characteristics, Journal of Archaeological Science 28, 913-928. https://doi.org/10.1006/jasc.2000.0605

Hepworth, J.V., 1972. The Mozambique orogenic belt and its foreland in northeast Tanzania: a photogeologically-based study. Journal of the Geological Society 128, 461-494.

Holmes, A., 1951. The sequence of Precambrian orogenic belts in south and central Africa, Proceed. 18th Internat. Geol. Congr. London 1948 14, 254-269

Hovers, E., 2009. Learning from mistakes: flaking accidents and knapping skills in the assemblage of AL 894 (Hadar, Ethiopia)

Howard, J.L., 2005. The quartzite problem revisited, The Journal of geology 113, 707 713. https://doi.org/10.1086/449328

Howell, F.C., 1961. Isimila: A Paleolithic site in Africa. Scientific American 205, 118 129.

Howell, F. C., Cole, G. H., Kleindienst, M. R., Haldemann, E. G., 1962. Isimila: An Acheulian Occupaton Site in the Iringa Highlands, Southern Highlands Province, Tanganyika (pp. 43-80). Tervuren: Musée royal de l'Afrique centrale.

Howell, F. C., Clark, J. D., 1963. Acheulian hunter-gatherers of sub-Saharan Africa. African ecology and human evolution, 458-533.

Howell, F.C., Haesaerts, P., de Heinzelin, J., 1987. Depositional environments, archeological occurrences and hominids from Members E and F of the Shungura Formation (Omo basin, Ethiopia), Journal of Human Evolution 16, 665-700. https://doi.org/10.1016/00472484(87)90019-4

Isaac, G., 1978. The food-sharing behavior of protohuman hominids, Scientific american 238, 90-109

Isaac, G.L., Harris, J., 1978. Archaeology. In (MG Leakey \& REF Leakey, Eds) Koobi Fora Research Project, vol. 1, Oxford: Clarendon Press

Isaac, G.L., Harris, J.W., Marshall, F., 1981. Small is informative: the application of the study of mini-sites and least effort criteria in the interpretation of the Early Pleistocene archaeological record at Koobi Fora, Kenya, The Archaeology of Human Origins. Papers by Glynn Isaac. Cambridge University Press, Cambridge, 259-268

Jack, R.N., Heizer, R.F., 1968. "Finger-Printing" of some Mesoamerican Obsidian Artifacts. Contributions of the University of California Archaeological Research Facility 5, 81100.

Jones, G.T., Beck, C., Jones, E.E., Hughes, R.E., 2003. Lithic source use and Paleoarchaic foraging territories in the Great Basin, American Antiquity 68, 5-38. https://doi.org/10.2307/3557031

Jones, P.R., 1979. Effects of Raw Materials on Biface Manufacture. Science 204 (4395), 835-836. 10.1126/science.204.4395.835.

Jones, P.R., 1980. Experimental butchery with modern stone tools and its relevance for Palaeolithic archaeology, World Archaeology 12, 153-165. https://doi.org/10.1080/00438243.1980.9979789 
Jones, P.R., 1981. Experimental implement manufacture and use: a case study from Olduvai Gorge, Tanzania. Philosophical Transactions of the Royal Society of London 292, 189195. https://doi.org/10.1098/rstb.1981.0027

Jones, P.R., 1994. Results of experimental work in relation to the stone industries of Oldupai Gorge, Oldupai Gorge 5, 1968-1971

Kabete, J., Groves, D., McNaughton, N., Mruma, A., 2012. A new tectonic and temporal framework for the Tanzanian Shield: implications for gold metallogeny and undiscovered endowment, Ore Geology Reviews 48, 88-124. https://doi.org/10.1016/j.oregeorev.2012.02.009

Kasanzu, C., Maboko, M.A., Manya, S., 2008. Geochemistry of fine-grained clastic sedimentary rocks of the Neoproterozoic Ikorongo Group, NE Tanzania: Implications for provenance and source rock weathering, Precambrian Research 164, 201 - 213.

https://doi.org/10.1016/j.precamres.2008.04.007

Kassambara, A., Mundt, F., 2017. Factoextra: Extract and Visualize the Results of Multivariate Data Analyses. R package version 1.0.5., https://CRAN.Rproject.org/package $=$ factoextra

Kaufulu, Z.M., Stern, N., 1987. The first stone artefacts to be found in situ within the Plio-Pleistocene Chiwondo Beds in northern Malawi, Journal of Human Evolution 16, 729-740. https://doi.org/10.1016/0047-2484(87)90021-2

Keiller, A., Piggott, S., Wallis, F.S., 1941. First Report of the Sub-Committee of the South-Western Group of Museums and Art Galleries on the Petrological Identification of Stone Axes. Proceedings of the Prehistoric Society 7, 50-72.

https://doi.org/10.1017/S0079497X00020272

Kröner, A., Stern, R., 2005. AFRICA| Pan-African orogen

Kuhn, S.L., 1991. "Unpacking" reduction: lithic raw material economy in the Mousterian of west-central Italy, Journal of Anthropological Archaeology 10, 76-106.

https://doi.org/10.1016/0278-4165(91)90022-P

Kuman, K., 1996. The Oldowan industry from Sterkfontein: raw materials and core forms.

Kuman, K., Clarke, R.J., 2000. Stratigraphy, artefact industries and hominid associations for Sterkfontein, Member 5, Journal of Human Evolution 38, 827-847.

https://doi.org/10.1006/jhev.1999.0392

Kuman, K., Field, A., 2009. The Oldowan industry from Sterkfontein Caves, South Africa, Stone Age Institute Press

Kyara, O., 1999. Lithic raw materials and their implications on assemblage variation and hominid behavior during Bed II, Oldupai Gorge, $\mathrm{PhD}$ diss., Rutgers University

Laplace, G., 1972. La typologie analytique et structurale: base rationnelle d'étude des industries lithiques et osseuses, Colloques nationaux du CNRS Banques de données archéologiques, 92-143

Le Gall, B., Nonnotte, P., Rolet, J., Benoit, M., Guillou, H., Mousseau-Nonnotte, M., Albaric, J., Déverchère, J., 2008. Rift propagation at craton margin.: Distribution of faulting and volcanism in the North Tanzanian Divergence (East Africa) during Neogene times, Tectonophysics 448, 1-19.https://doi.org/10.1016/j.tecto.2007.11.005

Lê, S., Josse, J., Husson, F., 2008. FactoMineR: an R package for multivariate analysis, Journal of statistical software 25, 1-18

Leakey, M., Roe, D., 1994. Oldupai Gorge: Volume 5, Excavations in Beds III, IV and the Masek Beds, Cambridge University Press.0521334039 
Leakey, M.D., 1971. Oldupai Gorge, Excavations in Beds I and II, 1960-1963, vol. 3.978-0-521-10518-7

Leakey, M.D., Hay, R.L., Thurber, D.L., Protsch, R., Berger, R., 1972. Stratigraphy, Archaeology, and Age of the Ndutu and Naisiusiu Beds, Oldupai Gorge, Tanzania. World Archaeology 3, 328-341.

Macgregor, D., 2015. History of the development of the East African Rift System: A series of interpreted maps through time. Journal of African Earth Sciences 101, 232-252. https://doi.org/10.1016/j.jafrearsci.2014.09.016

Mana, S., Furman, T., Carr, M., Mollel, G., Mortlock, R., Feigenson, M., Turrin, B., Swisher, C., 2012. Geochronology and geochemistry of the Essimingor volcano: melting of metasomatized lithospheric mantle beneath the North Tanzanian Divergence zone (East African Rift), Lithos 155, 310-325. https://doi.org/10.1016/j.lithos.2012.09.009

McHenry, L.J., de la Torre, I., 2018. Hominin raw material procurement in the OldowanAcheulean transition at Oldupai Gorge, Journal of human evolution. https://doi.org/10.1016/j.jhevol.2017.11.010

McHenry, L.J., Mollel, G.F., Swisher III, C.C., 2008. Compositional and textural correlations between Oldupai Gorge Bed I tephra and volcanic sources in the Ngorongoro Volcanic Highlands, Tanzania, Quaternary International 178, 306-319. https://doi.org/10.1016/j.quaint.2007.01.004

McNabb, J., Kuman, K., 2015. Experimental stone tool replication at the early stone age site of Sterkfontein, Gauteng, South Africa, Journal of Archaeological Science: Reports 4, 44-53. https://doi.org/10.1016/j.jasrep.2015.08.043

Melgarejo, J., 1997. Atlas de asociaciones minerales en lámina delgada.84-475-2762-X

Merrick, H.V., Merrick, J., 1976. Archaeological occurrences of earlier Pleistocene age from the Shungura Formation, Earliest man and environments in the Lake Rudolf Basin, 574584.

Mollel, G.F., 2002. Petrology and Geochemistry of the Southeastern Ngorongoro Volcanic Highland: And Contribution to" sourcing" of Stone Tools at Oldupai Gorge, Tanzania, Rutgers University

Mollel, G.F., 2007. Petrochemistry and geochronology of Ngorongoro volcanic highland complex (NVHC) and its relationship to Laetoli and Oldupai Gorge, Tanzania, Rutgers University-Graduate School-New Brunswick, p. 233

Mollel, G.F., Swisher III, C.C., 2012. The Ngorongoro Volcanic Highland and its relationships to volcanic deposits at Oldupai Gorge and East African Rift volcanism, Journal of human evolution 63, 274-283. https://doi.org/10.1016/j.jhevol.2011.09.001

Mollel, G.F., Swisher, C.C., Feigenson, M.D., Carr, M.J., 2008. Geochemical evolution of Ngorongoro Caldera, Northern Tanzania: Implications for crust-magma interaction, Earth and Planetary Science Letters 271, 337-347. https://doi.org/10.1016/j.eps1.2008.04.014

Mollel, G.F., Swisher, C.C., McHenry, L.J., Feigenson, M.D., Carr, M.J., 2009. Petrogenesis of basalt-trachyte lavas from Olmoti Crater, Tanzania, Journal of African Earth Sciences 54, 127-143. https://doi.org/10.1016/j.jafrearsci.2009.03.008

Morales, J.I., 2016. Distribution patterns of stone-tool reduction: Establishing frames of reference to approximate occupational features and formation processes in Paleolithic societies, Journal of Anthropological Archaeology 41, 231-245. https://doi.org/10.1016/j.jaa.2016.01.004

Odell, G.H., 2012. Lithic analysis, Springer Science \& Business Media.1441990097 
Parks, G.A., Tieh, T.T., 1966. Identifying the geographical Source of Artefact Obsidian. Nature 211, 289-290. https://doi.org/10.1038/211289a0

Perkins, D., Henke, K. R., 2002. Minerales en lámina delgada, Prentice Hall

Pettijohn, F.J., Potter, P.E., Siever, R., 2012. Sand and sandstone, Springer Science \& Business Media.1461210666

Pitblado, B.L., Dehler, C., Neff, H., Nelson, S.T., 2008. Pilot Study Experiments Sourcing Quartzite, Gunnison Basin, Colorado. Geoarchaeology 23, 742-778. https://doi.org/10.1002/gea.20240

Pitblado, B.L., Cannon, M.B., Neff, H., Dehler, C.M., Nelson, S.T., 2013. LA-ICP-MS analysis of quartzite from the Upper Gunnison Basin, Colorado. Journal of Archaeological Science 40, 2196-2216. https://doi.org/10.1016/j.jas.2012.11.016

Plummer, T., 2004. Flaked Stones and Old Bones: Biological and Cultural Evolution at the Dawn of Technology. Yearbook Of Physical Anthropology 47, 118-164.

https://doi.org/10.1002/ajpa.20157

Plummer, T.W., Bishop, L.C., Ditchfield, P.W., Ferraro, J.V., Kingston, J.D., Hertel, F., Braun, D.R., 2009. The environmental context of Oldowan hominin activities at Kanjera South, Kenya, Interdisciplinary approaches to the Oldowan, Springer, pp. 149-160

Potts, R., 1994. Variables versus models of early Pleistocene hominid land use, Journal of Human Evolution 27, 7-24. https://doi.org/10.1006/jhev.1994.1033

Poupeau, G., Le Bourdonnec, F.-X., Carter, T., Delerue, S., Shackley, M.S., Barrat, J.-A., Dubernet, S., Moretto, P., Calligaro, T., Milić, M., 2010. The use of SEM-EDS, PIXE and EDXRF for obsidian provenance studies in the Near East: a case study from Neolithic Çatalhöyük (central Anatolia), Journal of Archaeological Science 37, 2705-2720. https://doi.org/10.1016/j.jas.2010.06.007

Prieto, A., Yusta, I., Arrizabalaga, A., 2019. Defining and Characterizing Archaeological Quartzite: Sedimentary and Metamorphic Processes in the Lithic Assemblages of El Habario and El Arteu (Cantabrian Mountains, Northern Spain), Archaeometry 61, 14-30.

https://doi.org/10.1111/arcm.1239

Roberts, E.M., Stevens, N., O’Connor, P.M., Dirks, P., Gottfried, M.D., Clyde, W., Armstrong, R., Kemp, A., Hemming, S., 2012. Initiation of the western branch of the East African Rift coeval with the eastern branch, Nature Geoscience 5, 289.10.1038/NGEO1432 Roche, H., 1989. Technological evolution in early hominids, Ossa 14, 97-98

Sanislav, I., Wormald, R., Dirks, P., Blenkinsop, T.G., Salamba, L., Joseph, D., 2014. Zircon $\mathrm{U}-\mathrm{Pb}$ ages and $\mathrm{Lu}-\mathrm{Hf}$ isotope systematics from late-tectonic granites, Geita Greenstone Belt: Implications for crustal growth of the Tanzania Craton, Precambrian research 242, 187 204. https://doi.org/10.1016/j.precamres.2013.12.026

Roebroeks, W., 1988. From find scatters to early hominid behaviour: a study of Middle Palaeolithic riverside settlements at Maastricht-Belvédère (The Netherlands). Analecta Praehistorica Leidensia, vol. 21, University of Leiden: Leiden.

Santonja, M., Panera, J., Rubio-Jara, S., Pérez-González, A., Uribelarrea, D., Domínguez-Rodrigo, M., Mabulla, A.Z., Bunn, H.T., Baquedano, E., 2014. Technological strategies and the economy of raw materials in the TK (Thiongo Korongo) lower occupation, Bed II, Oldupai Gorge, Tanzania, Quaternary International 322, 181-208. https://doi.org/10.1016/j.quaint.2013.10.069

Scoon, R.N., 2018. The Gregory Rift, Geology of National Parks of Central/Southern Kenya and Northern Tanzania, Springer, pp. 39-57 
Semaw, S., 2006. The oldest stone artifacts from Gona (2.6-2.5 Ma), Afar, Ethiopia: Implications for understanding the earliest stages of stone knapping, The Oldowan: Case studies into the earliest stone age, 43-75

Shackley, M.S., 1998. Geochemical differentiation and prehistoric procurement of obsidian in the Mount Taylor volcanic field, northwest New Mexico, Journal of Archaeological Science 25, 1073-1082. https://doi.org/10.1006/jasc.1998.0274

Shackley, M.S., 2008. Archaeological petrology and the archaeometry of lithic materials, Archaeometry 50, 194-215. https://doi.org/10.1111/j.1475-4754.2008.00390.x

Sheppard, P.J., Kleindienst, M.R., 1996. Technological change in the earlier and middle stone Age of Kalambo Falls (Zambia), African Archaeological Review 13, 171-196. https://doi.org/10.1007/BF01963510

Schick, K.D., 1987. Modeling the formation of Early Stone Age artifact concentrations, Journal of human evolution 16, 789-807.https://doi.org/10.1016/0047-2484(87)90024-8

Shott, M.J., Ballenger, J.A., 2007. Biface reduction and the measurement of Dalton curation: a southeastern United States case study, American Antiquity 72, 153-175. https://doi.org/10.2307/40035302

Shotton, F., Hendry, G., 1979. The developing field of petrology in archaeology, Journal of Archaeological Science 6, 75-84. https://doi.org/10.1016/0305-4403(79)90034-7

Skolnick, H., 1965. The quartzite problem, Journal of Sedimentary Research 35, 12-21. https://doi.org/10.1306/74D711E0-2B21-11D7-8648000102C1865D

Stiles, D., 1991. Early hominid behaviour and culture tradition: raw material studies in Bed II, Oldupai Gorge, African Archaeological Review 9, 1-19. https://doi.org/10.1007/BF01117214

Stiles, D., 2003. Raw material as evidence for human behaviour in the Lower Pleistocene: the Oldupai case, Early Human Behaviour in Global Context, Routledge, pp. 149164

Stiles, D., Hay, R., O'Neil, J., 1974. The MNK chert factory site, Oldupai Gorge, Tanzania, World Archaeology 5, 285-308. https://doi.org/10.1080/00438243.1974.9979575

Tactikos, J.C., 2005. A landscape perspective on the Oldowan from Oldupai Gorge, Tanzania, Department of Anthropology, Rutgers, the State University of New Jersey

$\mathrm{R}$ Core Team, 2017. R: a language and environment for statistical computing. $\mathrm{R}$ Foundation for Statistical Computing, Vienna. http s, www. R-project. Org

Toth, N., 1985. Archaeological evidence for preferential right-handedness in the Lower and Middle Pleistocene, and its possible implications, Journal of Human Evolution 14, 607-614. https://doi.org/10.1016/S0047-2484(85)80087-7

Toth, N.P., 1982. The stone technologies of early hominids at Koobi Fora, Kenya: an experimental approach, University of California, Berkeley

Tucker, M.E., 2009. Sedimentary petrology: an introduction to the origin of sedimentary rocks, John Wiley \& Sons.144431159X

Vaquero, M., Pastó, I. (2001). The definition of spatial units in Middle Palaeolithic sites: the hearth-related assemblages. Journal of Archaeological Science, 28(11), 1209-1220.

https://doi.org/10.1006/jasc.2001.0656

Vaquero, M. (2008). The history of stones: behavioural inferences and temporal resolution of an archaeological assemblage from the Middle Palaeolithic. Journal of Archaeological Science, 35(12), 3178-3185. https://doi.org/10.1016/j.jas.2008.07.006 
Veldeman, I., Baele, J.-M., Goemaere, E., Deceukelaire, M., Dusar, M., De Doncker, H.W.J.A., 2012. Characterizing the hypersiliceous rocks of Belgium used in (pre-)history: a case study on sourcing sedimentary quartzites. Journal of Geophysics and Engineering 9, S118-S128. https://doi.org/10.1088/1742-2132/9/4/S118

Weaver, J., Stross, F., 1965. Analysis by x-ray fluorescence of some American obsidians. Contributions of the University of California Archaeological Research Facility 1, 89-93.

Wilson, L., 2007. Understanding prehistoric lithic raw material selection: application of a gravity model, Journal of Archaeological Method and Theory 14, 388-411.

https://doi.org/10.1007/s10816-007-9042-4

Wilson, L., Browne, C.L., Texier, P.-J., 2018. Provisioning on the periphery: Middle Palaeolithic raw material supply strategies on the outer edge of a territory at La Combette (France), Journal of Archaeological Science: Reports 21, 87-98.

https://doi.org/10.1016/j.jasrep.2018.07.001

Zaitsev, A., Marks, M., Wenzel, T., Spratt, J., Sharygin, V., Strekopytov, S., Markl, G., 2012. Mineralogy, geochemistry and petrology of the phonolitic to nephelinitic Sadiman volcano, Crater Highlands, Tanzania, Lithos 152, 66-83.

https://doi.org/10.1016/j.lithos.2012.03.001 


\section{Supplementary Materials}

a)

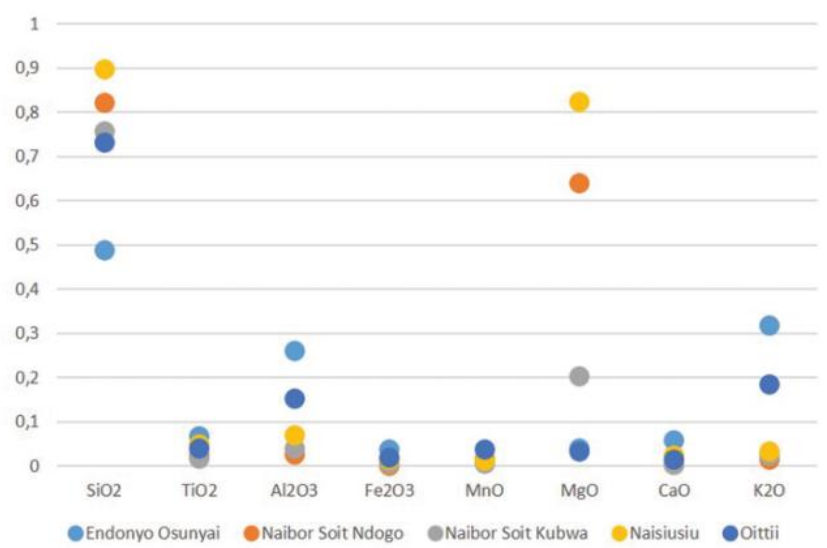

b)

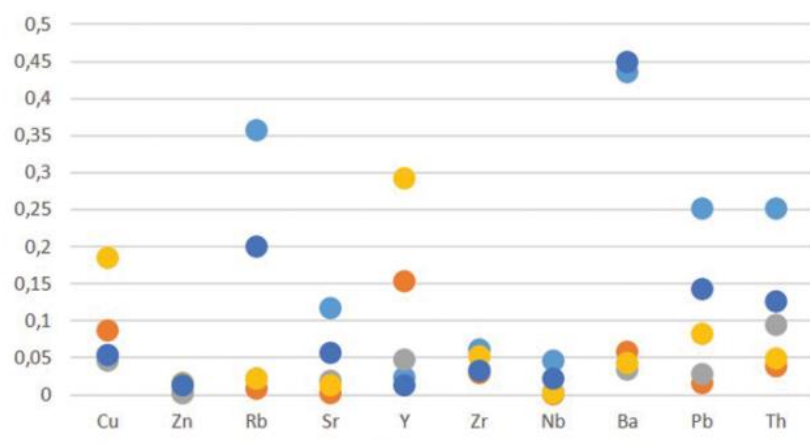

-Endonyo Osunyai @ Naibor Soit Ndogo enaibor Soit Kubwa ONaisiusiu •

c)

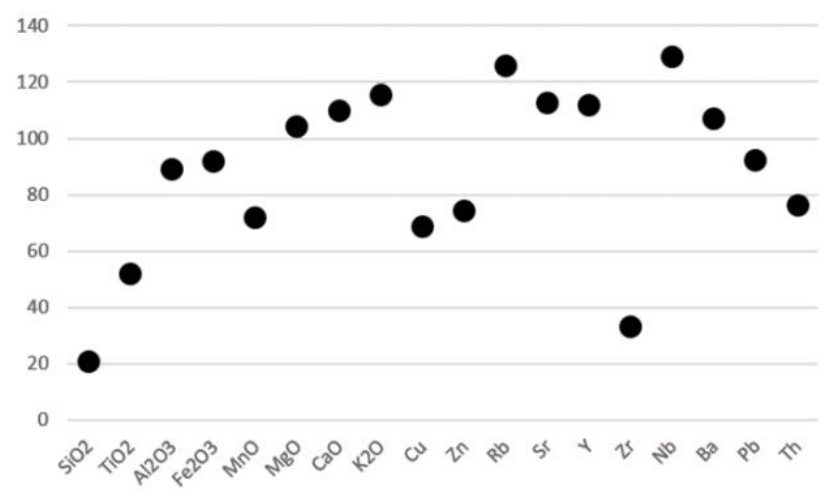

Fig. 1. a, b) Plotting of averaged concentrations for major oxide and trace element concentrations per outcrop showing the inter-outcrop variability; c) Relative Standard Deviations. 
a)

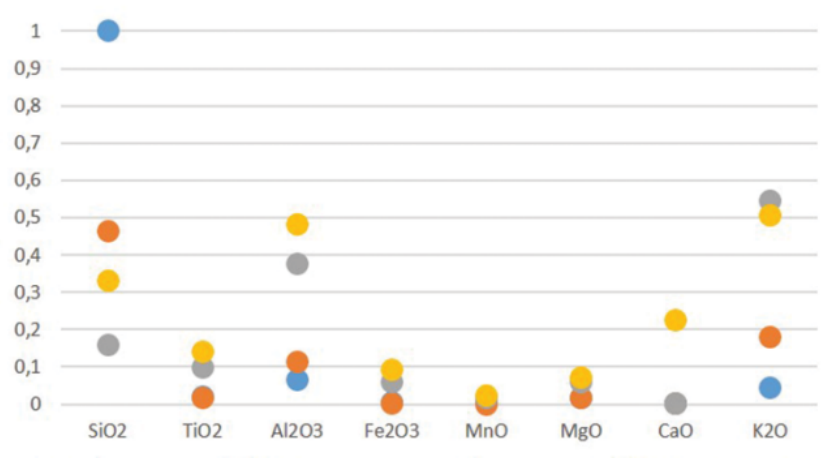

- Endonyo Osunyai 2 Endonyo Osunyai 3 Endonyo Osunyai 4 Endonyo Osunyai 5

b)

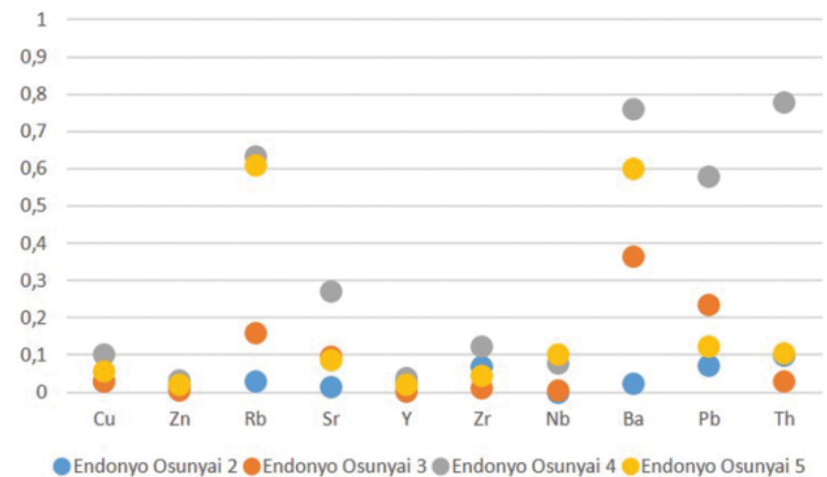

c)

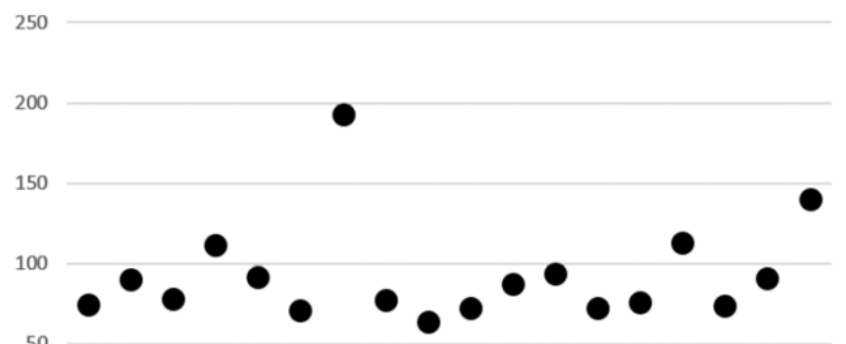

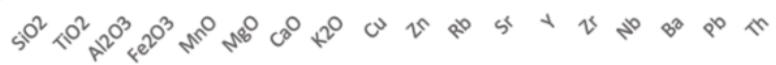

Fig. 2. a, b) Plotting of major oxide and trace element concentrations for samples from Endonyo Osunyai; c) Relative Standard Deviations for samples from Endonyo Osunyai showing the intraoutcrop variability. 
a)

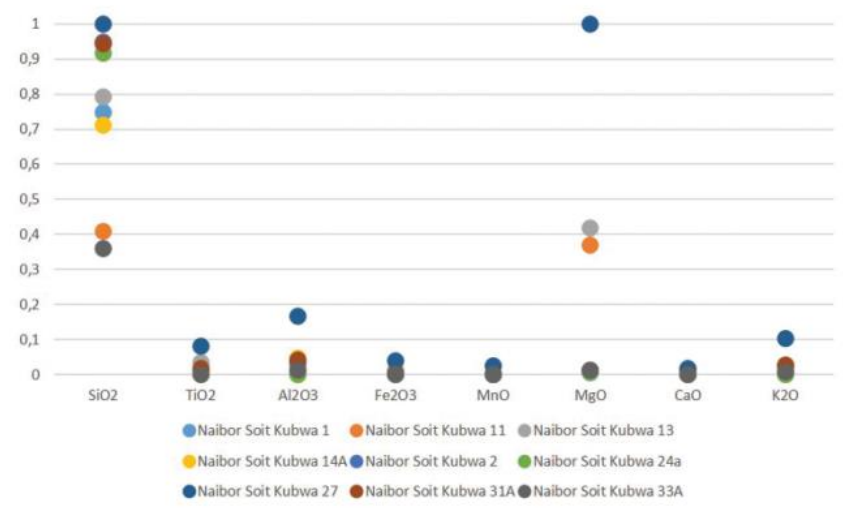

b)

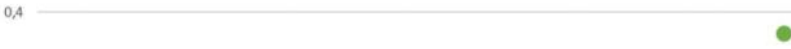

0,3

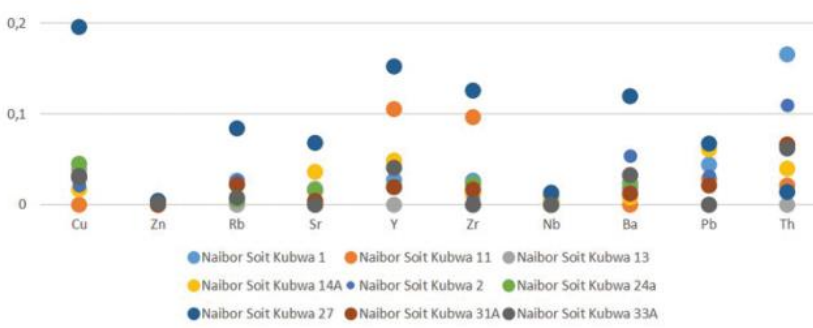

c)

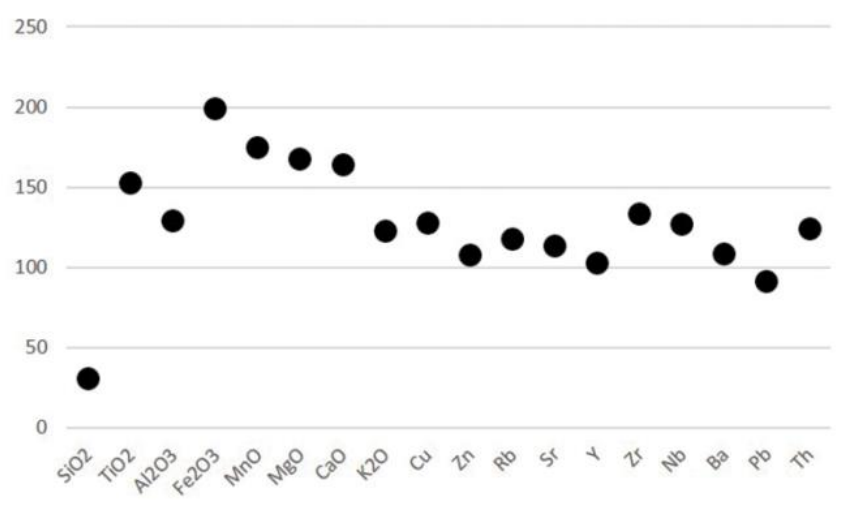

Fig. 3. a, b) Plotting of major oxide and trace element concentrations for samples from Naibor Soit Kubwa; c) Relative Standard Deviations for samples from Naibor Soit Kubwa showing the intra-outcrop variability. 
a)

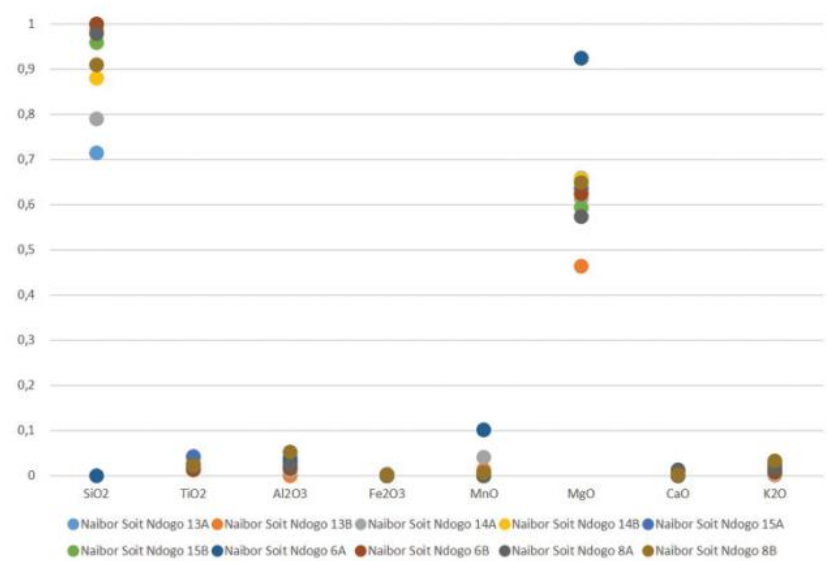

b)

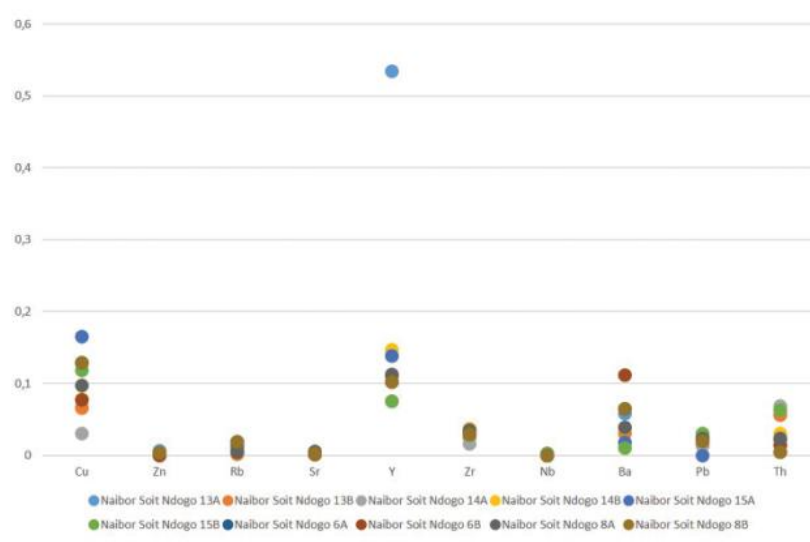

c)

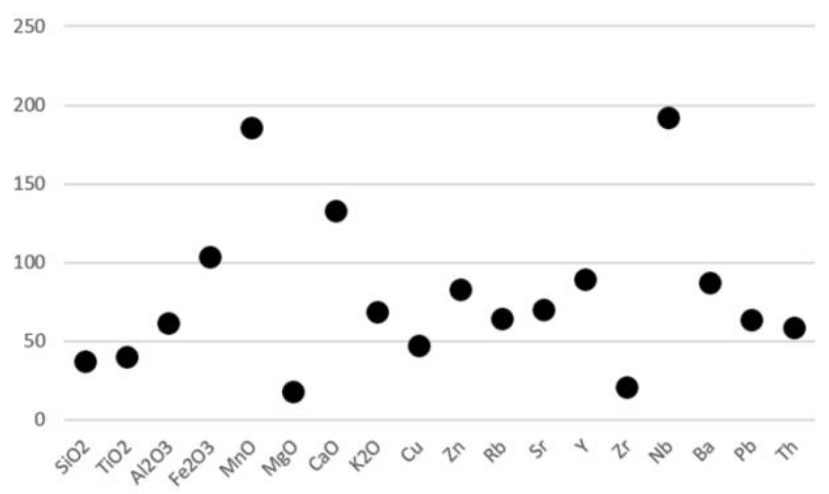

Fig. 4. a, b) Plotting of major oxide and trace element concentrations for samples from Naibor Soit Ndogo; c) Relative Standard Deviations for samples from Naibor Soit Ndogo showing the intra-outcrop variability. 
a)

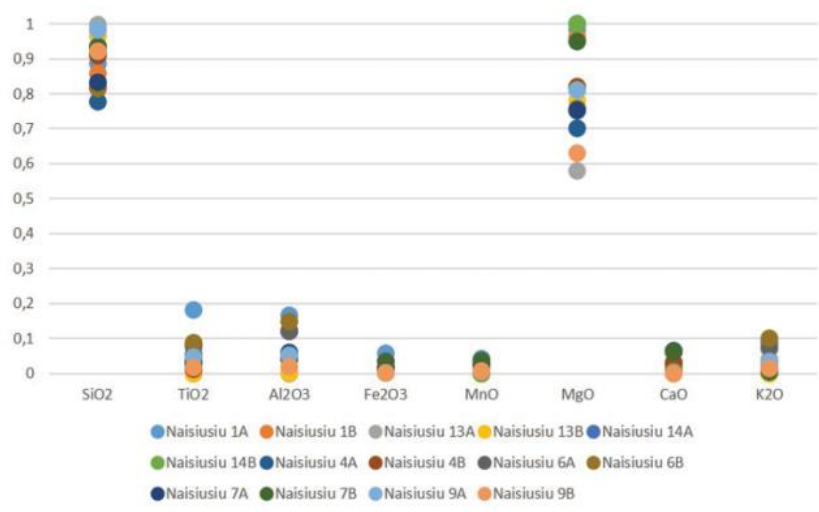

b)

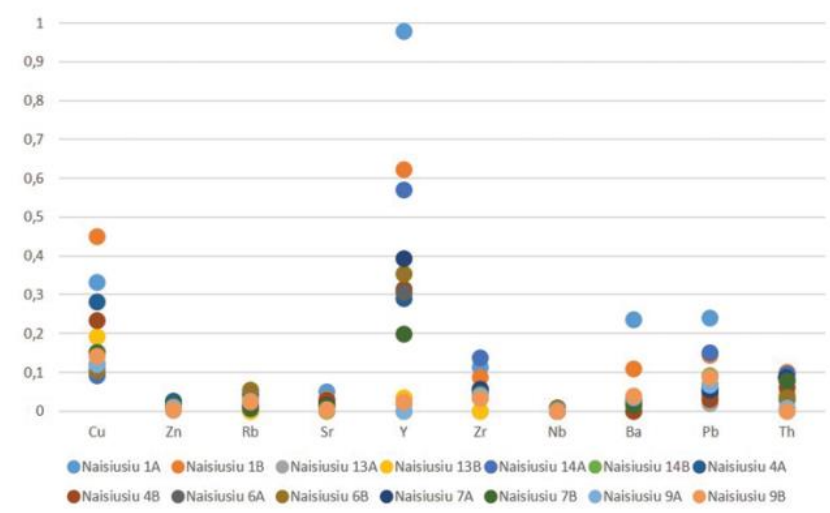

c)

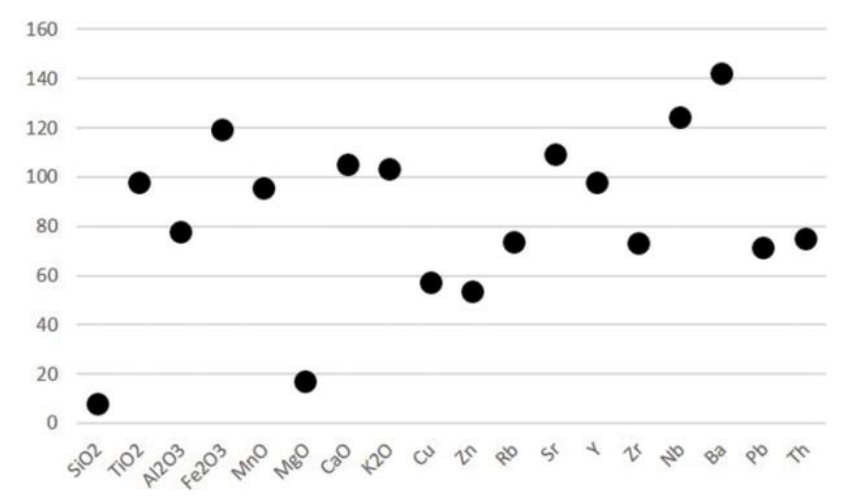

Fig. 5. a, b) Plotting of major oxide and trace element concentrations for samples from Naisiusiu; c) Relative Standard Deviations for samples from Naisiusiu showing the intra-outcrop variability. 
a)

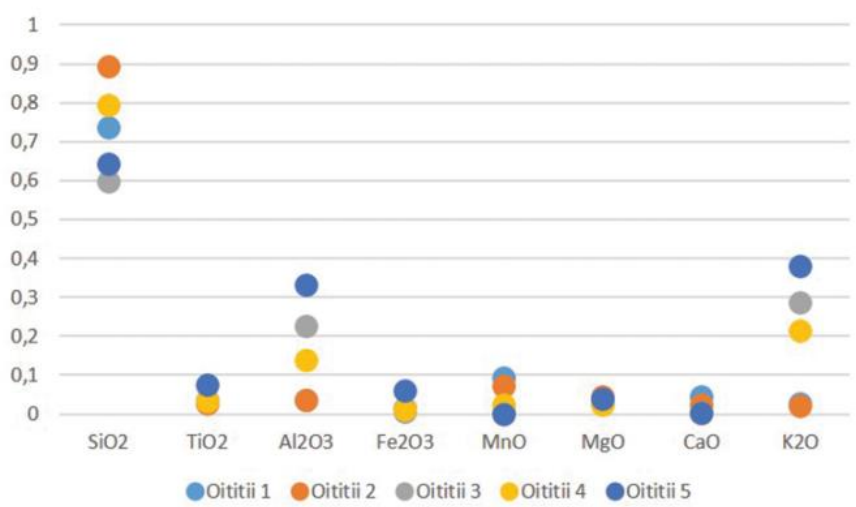

b)

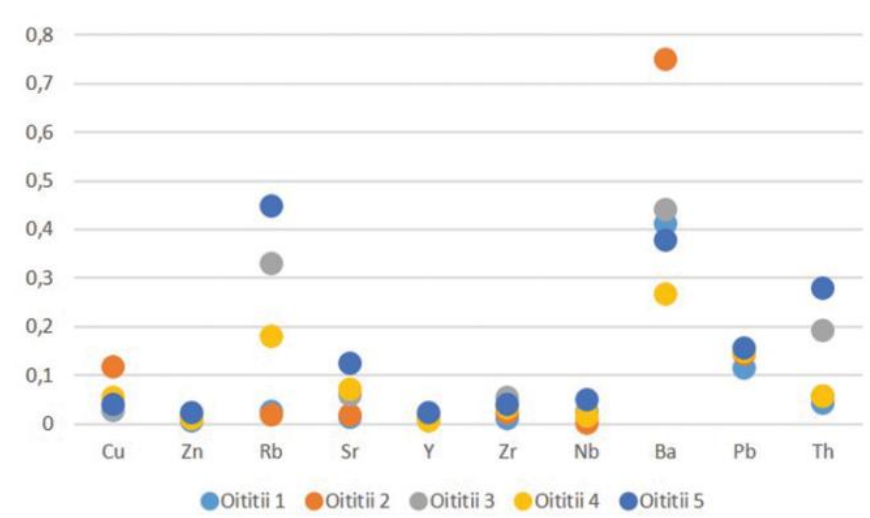

c)

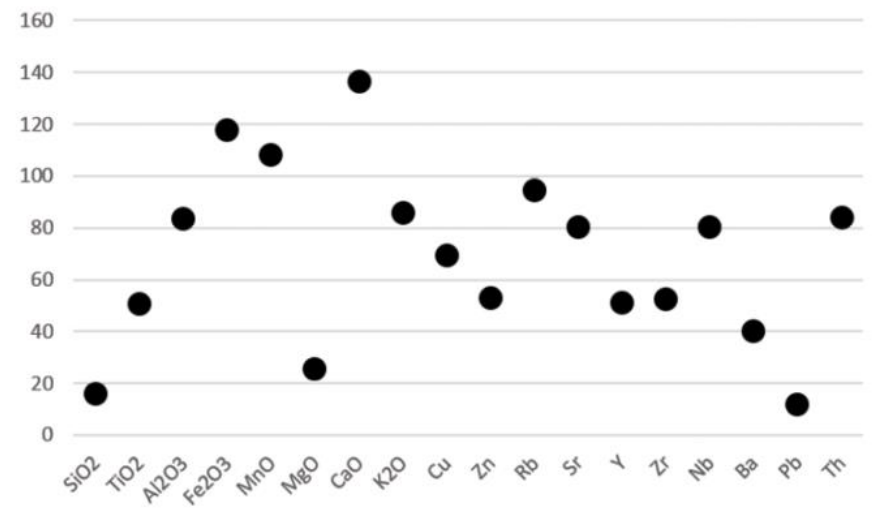

Fig. 6. a, b) Plotting of major oxide and trace element concentrations for samples from Oittii; c) Relative Standard Deviations for samples from Oittii showing the intra-outcrop variability. 

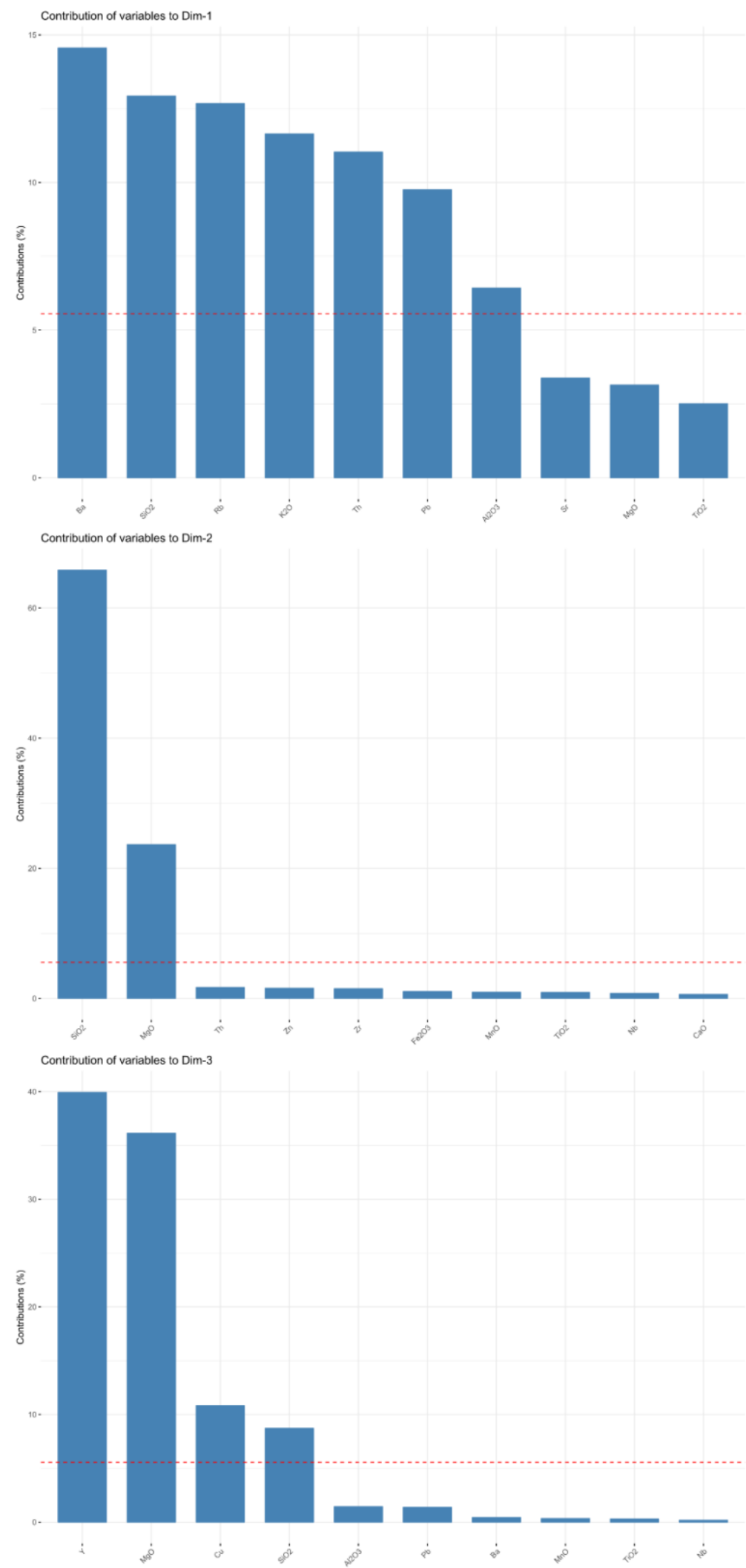

Fig. 7. PCA contribution percentages of the three components based on EDXRF data. 


\begin{tabular}{|c|c|}
\hline RMGs (McHenry and de la Torre, 2018) & RMGs (this study) \\
\hline 7.1 & $\mathrm{~W}^{*}$ \\
\hline 7.1 .1 & $\mathrm{~W}^{*}$ \\
\hline 7.1 .2 & $\mathrm{~W}^{*}$ \\
\hline 7.1 .3 & $\mathrm{~W}^{*}$ \\
\hline 7.1 .4 & $\mathrm{~W}^{*}$ \\
\hline 7.2 & $\mathrm{R} 5$ \\
\hline 7.3 & $\mathrm{~W} 3 / \mathrm{W} 4$ \\
\hline 7.4 & $\mathrm{G} 1$ \\
\hline 7.5 & $\mathrm{Gr}$ \\
\hline 7.5 .1 & $\mathrm{Gr} 1$ \\
\hline 7.6 & $\mathrm{~W} 1 / \mathrm{W} 2 / \mathrm{Gr} 2$ \\
\hline 7.6 .1 & $\mathrm{Gr} 1$ \\
\hline 7.6 .2 & $\mathrm{R} 2$ \\
\hline 7.7 & $\mathrm{~W} *$ \\
\hline 7.8 & $\mathrm{nd}$ \\
\hline 7.9 & $\mathrm{nd}$ \\
\hline & \\
\hline
\end{tabular}

Table 1. Correlation between quartzite RMGs identified in McHenry and de la Torre (2018) and those in this study.

* Specific RMGs were only correlated where possible, and to avoid misclassification, some were only correlated at a general level. 


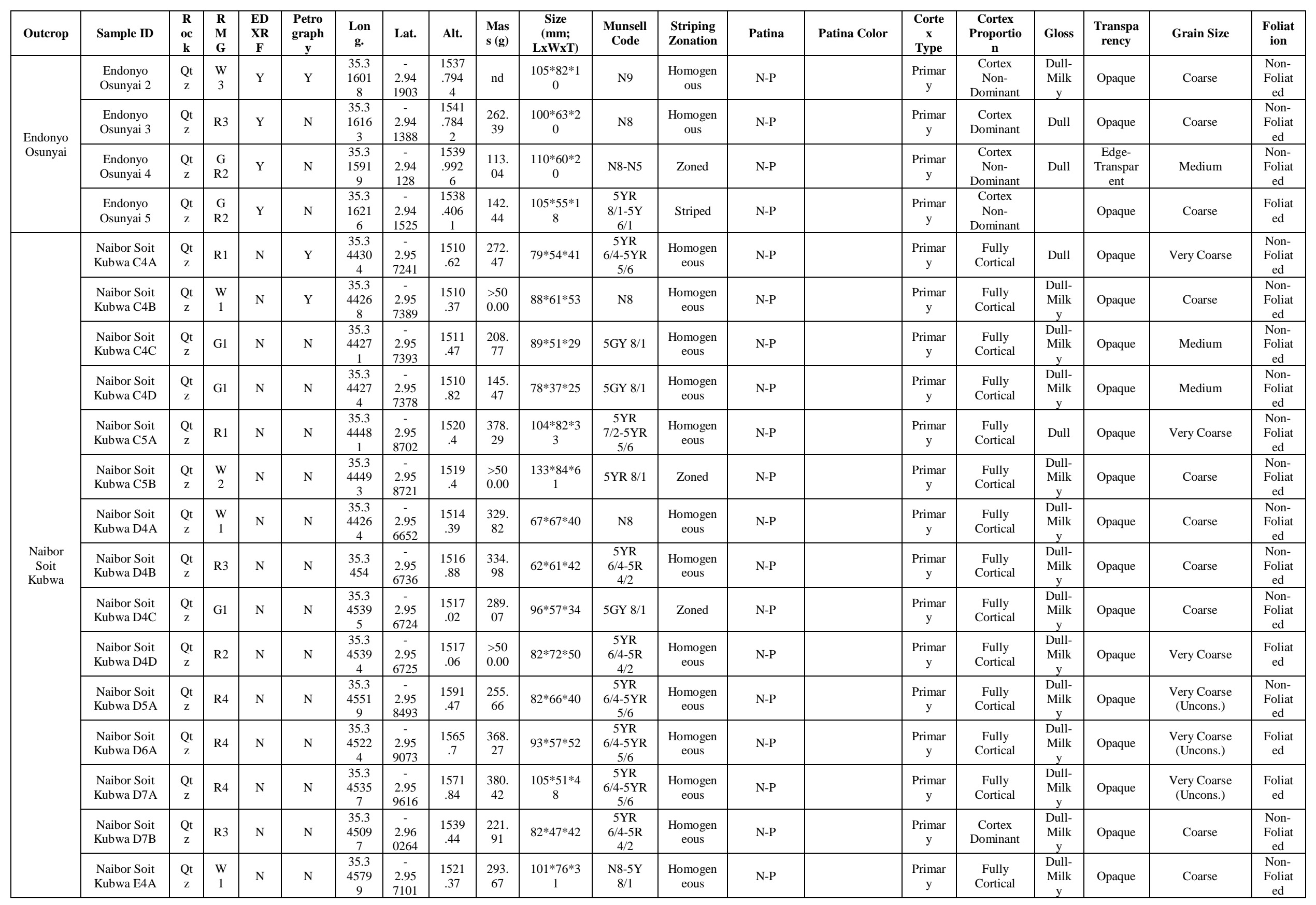




\begin{tabular}{|c|c|c|c|c|c|c|c|c|c|c|c|c|c|c|c|c|c|c|c|c|}
\hline Outcrop & Sample ID & $\begin{array}{l}\mathbf{R} \\
\mathbf{o c} \\
\mathbf{k} \\
\end{array}$ & $\begin{array}{l}\mathbf{R} \\
\mathbf{M} \\
\mathbf{G} \\
\end{array}$ & $\begin{array}{c}\text { ED } \\
\text { XR } \\
\text { F } \\
\end{array}$ & $\begin{array}{c}\begin{array}{c}\text { Petro } \\
\text { graph } \\
\mathbf{y}\end{array} \\
\end{array}$ & $\begin{array}{c}\text { Lon } \\
\text { g. }\end{array}$ & Lat. & Alt. & $\begin{array}{l}\text { Mas } \\
\text { s (g) }\end{array}$ & $\begin{array}{c}\text { Size } \\
\text { (mm; } \\
\text { LxWxT) }\end{array}$ & $\begin{array}{l}\text { Munsell } \\
\text { Code }\end{array}$ & $\begin{array}{l}\text { Striping } \\
\text { Zonation }\end{array}$ & Patina & Patina Color & $\begin{array}{c}\text { Corte } \\
\text { x } \\
\text { Type } \\
\end{array}$ & $\begin{array}{c}\text { Cortex } \\
\text { Proportio } \\
\text { n }\end{array}$ & Gloss & $\begin{array}{c}\text { Transpa } \\
\text { rency }\end{array}$ & Grain Size & $\begin{array}{c}\text { Foliat } \\
\text { ion }\end{array}$ \\
\hline & $\begin{array}{l}\text { Naibor Soit } \\
\text { Kubwa E4B }\end{array}$ & $\begin{array}{l}\mathrm{Qt} \\
\mathrm{z}\end{array}$ & G1 & $\mathrm{N}$ & $\mathrm{N}$ & $\begin{array}{c}35.3 \\
4579 \\
8 \\
\end{array}$ & $\begin{array}{c}- \\
2.95 \\
7093 \\
\end{array}$ & $\begin{array}{l}1520 \\
.87\end{array}$ & $\begin{array}{c}350 . \\
56\end{array}$ & $\begin{array}{c}121 * 68 * 2 \\
6\end{array}$ & $5 \mathrm{GY} 8 / 1$ & $\begin{array}{l}\text { Homogen } \\
\text { eous }\end{array}$ & N-P & & $\begin{array}{c}\text { Primar } \\
\text { y }\end{array}$ & $\begin{array}{c}\text { Fully } \\
\text { Cortical }\end{array}$ & $\begin{array}{c}\text { Dull- } \\
\text { Milk } \\
\mathrm{y}\end{array}$ & Opaque & Coarse & $\begin{array}{l}\text { Foliat } \\
\text { ed }\end{array}$ \\
\hline & $\begin{array}{l}\text { Naibor Soit } \\
\text { Kubwa E5A }\end{array}$ & $\begin{array}{l}\text { Qt } \\
\mathrm{z}\end{array}$ & $\begin{array}{l}\mathrm{W} \\
1\end{array}$ & $\mathrm{~N}$ & $\mathrm{~N}$ & $\begin{array}{c}35.3 \\
4633 \\
6 \\
\end{array}$ & $\begin{array}{r}- \\
2.95 \\
7749 \\
\end{array}$ & $\begin{array}{l}1529 \\
.25\end{array}$ & $\begin{array}{c}234 . \\
62\end{array}$ & $77 * 58 * 25$ & $\begin{array}{c}\text { N8-5Y } \\
8 / 1\end{array}$ & $\begin{array}{c}\text { Homogen } \\
\text { eous }\end{array}$ & N-P & & $\begin{array}{c}\text { Primar } \\
\text { y }\end{array}$ & $\begin{array}{c}\text { Fully } \\
\text { Cortical }\end{array}$ & $\begin{array}{c}\text { Dull- } \\
\text { Milk } \\
\mathrm{y}\end{array}$ & Opaque & Coarse & $\begin{array}{c}\text { Non- } \\
\text { Foliat } \\
\text { ed }\end{array}$ \\
\hline & $\begin{array}{l}\text { Naibor Soit } \\
\text { Kubwa E5B }\end{array}$ & $\begin{array}{l}\text { Qt } \\
\mathrm{z}\end{array}$ & $\mathrm{R} 2$ & $\mathrm{~N}$ & $\mathrm{~N}$ & $\begin{array}{c}35.3 \\
4633 \\
9 \\
\end{array}$ & $\begin{array}{l}2.95 \\
775\end{array}$ & $\begin{array}{l}1529 \\
.21\end{array}$ & $\begin{array}{c}373 . \\
92\end{array}$ & $82 * 64 * 53$ & $\begin{array}{c}\text { YYR } \\
6 / 4-5 \mathrm{R} \\
4 / 2 \\
\end{array}$ & $\begin{array}{c}\text { Homogen } \\
\text { eous }\end{array}$ & N-P & & $\begin{array}{c}\text { Primar } \\
\text { y }\end{array}$ & $\begin{array}{c}\text { Fully } \\
\text { Cortical }\end{array}$ & Dull & Opaque & Coarse & $\begin{array}{c}\text { Foliat } \\
\text { ed }\end{array}$ \\
\hline & $\begin{array}{l}\text { Naibor Soit } \\
\text { Kubwa E5C }\end{array}$ & $\begin{array}{l}\text { Qt } \\
\mathrm{z}\end{array}$ & G1 & $\mathrm{N}$ & $\mathrm{N}$ & $\begin{array}{c}35.3 \\
4634 \\
3 \\
\end{array}$ & $\begin{array}{r}- \\
2.95 \\
7739 \\
\end{array}$ & $\begin{array}{l}1531 \\
.17\end{array}$ & $\begin{array}{c}321 . \\
41\end{array}$ & $\begin{array}{c}102 * 59 * 3 \\
2\end{array}$ & $5 \mathrm{GY} 8 / 1$ & $\begin{array}{c}\text { Homogen } \\
\text { eous }\end{array}$ & N-P & & $\begin{array}{c}\text { Primar } \\
\text { y }\end{array}$ & $\begin{array}{l}\text { Fully } \\
\text { Cortical }\end{array}$ & Dull & Opaque & Coarse-Medium & $\begin{array}{c}\text { Foliat } \\
\text { ed }\end{array}$ \\
\hline & $\begin{array}{l}\text { Naibor Soit } \\
\text { Kubwa E5D }\end{array}$ & $\begin{array}{l}\text { Qt } \\
\mathrm{z}\end{array}$ & R3 & $\mathrm{N}$ & $\mathrm{N}$ & $\begin{array}{c}35.3 \\
4634 \\
6 \\
\end{array}$ & $\begin{array}{r}- \\
2.95 \\
7738 \\
\end{array}$ & $\begin{array}{c}1531 \\
.87\end{array}$ & $\begin{array}{l}>50 \\
0.00\end{array}$ & $81 * 67 * 43$ & $\begin{array}{c}5 \mathrm{YR} \\
6 / 4-5 \mathrm{R} \\
4 / 2 \\
\end{array}$ & $\begin{array}{c}\text { Homogen } \\
\text { eous }\end{array}$ & N-P & & $\begin{array}{c}\text { Primar } \\
\text { y }\end{array}$ & $\begin{array}{c}\text { Fully } \\
\text { Cortical }\end{array}$ & Dull & Opaque & Coarse & $\begin{array}{c}\text { Non- } \\
\text { Foliat } \\
\text { ed }\end{array}$ \\
\hline & $\begin{array}{l}\text { Naibor Soit } \\
\text { Kubwa E5E }\end{array}$ & $\begin{array}{l}\text { Qt } \\
\mathrm{z}\end{array}$ & R4 & $\mathrm{N}$ & $\mathrm{N}$ & $\begin{array}{c}35.3 \\
4634 \\
3 \\
\end{array}$ & $\begin{array}{r}2.95 \\
7747\end{array}$ & $\begin{array}{l}1532 \\
.03\end{array}$ & $\begin{array}{l}214 . \\
83\end{array}$ & $86 * 67 * 36$ & $\begin{array}{c}5 \mathrm{YR} \\
6 / 4-5 \mathrm{YR} \\
5 / 6 \\
\end{array}$ & $\begin{array}{c}\text { Homogen } \\
\text { eous }\end{array}$ & N-P & & $\begin{array}{c}\text { Primar } \\
\text { y }\end{array}$ & $\begin{array}{c}\text { Fully } \\
\text { Cortical }\end{array}$ & Dull & Opaque & $\begin{array}{l}\text { Very Coarse } \\
\text { (Uncons.) }\end{array}$ & $\begin{array}{l}\text { Foliat } \\
\text { ed }\end{array}$ \\
\hline & $\begin{array}{l}\text { Naibor Soit } \\
\text { Kubwa E6A }\end{array}$ & $\begin{array}{l}\text { Qt } \\
\mathrm{z}\end{array}$ & $\mathrm{R} 1$ & $\mathrm{~N}$ & $\mathrm{~N}$ & $\begin{array}{c}35.3 \\
4570 \\
9 \\
\end{array}$ & $\begin{array}{r}2.95 \\
8902 \\
\end{array}$ & $\begin{array}{c}1600 \\
.4\end{array}$ & $\begin{array}{c}288 . \\
67\end{array}$ & $96 * 54 * 37$ & $\begin{array}{c}5 \mathrm{YR} \\
6 / 4-5 \mathrm{YR} \\
5 / 6 \\
\end{array}$ & $\begin{array}{c}\text { Homogen } \\
\text { eous }\end{array}$ & N-P & & $\begin{array}{c}\text { Primar } \\
\text { y }\end{array}$ & $\begin{array}{c}\text { Cortex } \\
\text { Dominant }\end{array}$ & Dull & Opaque & Coarse & $\begin{array}{c}\text { Non- } \\
\text { Foliat } \\
\text { ed }\end{array}$ \\
\hline & $\begin{array}{l}\text { Naibor Soit } \\
\text { Kubwa E7A }\end{array}$ & $\begin{array}{l}\text { Qt } \\
\mathrm{z}\end{array}$ & $\mathrm{R} 1$ & $\mathrm{~N}$ & $\mathrm{~N}$ & $\begin{array}{c}35.3 \\
4535 \\
3 \\
\end{array}$ & $\begin{array}{r}- \\
2.95 \\
9585 \\
\end{array}$ & $\begin{array}{c}1571 \\
.84\end{array}$ & $\begin{array}{c}256 . \\
81\end{array}$ & $92 * 73 * 28$ & $\begin{array}{c}5 \mathrm{YR} \\
6 / 4-5 \mathrm{YR} \\
5 / 6 \\
\end{array}$ & $\begin{array}{c}\text { Homogen } \\
\text { eous }\end{array}$ & N-P & & $\begin{array}{c}\text { Primar } \\
\text { y }\end{array}$ & $\begin{array}{c}\text { Cortex } \\
\text { Dominant }\end{array}$ & Dull & Opaque & $\begin{array}{l}\text { Very Coarse- } \\
\text { Coarse }\end{array}$ & $\begin{array}{l}\text { Non- } \\
\text { Foliat } \\
\text { ed }\end{array}$ \\
\hline & $\begin{array}{l}\text { Naibor Soit } \\
\text { Kubwa E8A }\end{array}$ & $\begin{array}{l}\text { Qt } \\
\mathrm{z}\end{array}$ & $\mathrm{R} 4$ & $\mathrm{~N}$ & $\mathrm{~N}$ & $\begin{array}{c}35.3 \\
4702 \\
5 \\
\end{array}$ & $\begin{array}{c}- \\
2.96 \\
235 \\
\end{array}$ & $\begin{array}{c}1566 \\
.7\end{array}$ & $\begin{array}{c}361 . \\
10\end{array}$ & $\begin{array}{c}113 * 61 * 4 \\
2\end{array}$ & 5YR 5/6 & $\begin{array}{c}\text { Homogen } \\
\text { eous }\end{array}$ & N-P & & $\begin{array}{c}\text { Primar } \\
y\end{array}$ & $\begin{array}{c}\text { Cortex } \\
\text { Dominant }\end{array}$ & $\begin{array}{c}\text { Dull- } \\
\text { Milk } \\
\mathrm{y}\end{array}$ & Opaque & Coarse-Medium & $\begin{array}{c}\text { Foliat } \\
\text { ed }\end{array}$ \\
\hline & $\begin{array}{c}\text { Naibor Soit } \\
\text { Kubwa F11A }\end{array}$ & $\begin{array}{l}\text { Qt } \\
\mathrm{z}\end{array}$ & $\begin{array}{l}\mathrm{W} \\
1\end{array}$ & $\mathrm{~N}$ & $\mathrm{~N}$ & $\begin{array}{c}35.3 \\
4588 \\
3\end{array}$ & $\begin{array}{r}- \\
2.96 \\
2445\end{array}$ & $\begin{array}{l}1531 \\
.74\end{array}$ & $\begin{array}{c}384 . \\
32\end{array}$ & $\begin{array}{c}105 * 65 * 4 \\
7\end{array}$ & $\begin{array}{c}\text { N8-5Y } \\
8 / 1\end{array}$ & $\begin{array}{c}\text { Homogen } \\
\text { eous }\end{array}$ & N-P & & $\begin{array}{c}\text { Primar } \\
\text { y }\end{array}$ & $\begin{array}{c}\text { Cortex } \\
\text { Dominant }\end{array}$ & $\begin{array}{c}\text { Milk } \\
\text { y }\end{array}$ & Opaque & Coarse & $\begin{array}{c}\text { Foliat } \\
\text { ed }\end{array}$ \\
\hline & $\begin{array}{c}\text { Naibor Soit } \\
\text { Kubwa F11C }\end{array}$ & $\begin{array}{l}\mathrm{Qt} \\
\mathrm{z}\end{array}$ & $\begin{array}{c}\mathrm{G} \\
\mathrm{R} 1\end{array}$ & $\mathrm{~N}$ & $\mathrm{~N}$ & $\begin{array}{c}35.3 \\
4589 \\
8 \\
\end{array}$ & $\begin{array}{c}- \\
2.96 \\
2448 \\
\end{array}$ & $\begin{array}{l}1531 \\
.64\end{array}$ & $\begin{array}{c}339 . \\
14\end{array}$ & $94 * 91 * 55$ & $\begin{array}{l}5 \mathrm{~PB} 5 / 2- \\
5 \mathrm{~PB} 7 / 2\end{array}$ & $\begin{array}{l}\text { Homogen } \\
\text { eous }\end{array}$ & N-P & & $\begin{array}{c}\text { Primar } \\
\text { y }\end{array}$ & $\begin{array}{c}\text { Cortex } \\
\text { Dominant }\end{array}$ & $\begin{array}{c}\text { Milk } \\
\mathrm{y}\end{array}$ & Opaque & Coarse-Medium & $\begin{array}{c}\text { Foliat } \\
\text { ed }\end{array}$ \\
\hline & $\begin{array}{l}\text { Naibor Soit } \\
\text { Kubwa F5A }\end{array}$ & $\begin{array}{l}\text { Qt } \\
\mathrm{z}\end{array}$ & $\begin{array}{l}\mathrm{W} \\
3\end{array}$ & $\mathrm{~N}$ & $\mathrm{~N}$ & $\begin{array}{c}35.3 \\
4743 \\
7 \\
\end{array}$ & $\begin{array}{c}- \\
2.95 \\
8407 \\
\end{array}$ & $\begin{array}{c}1536 \\
.4\end{array}$ & $\begin{array}{c}390 . \\
49\end{array}$ & $\begin{array}{c}105 * 101 * \\
37\end{array}$ & N9 & $\begin{array}{c}\text { Homogen } \\
\text { eous }\end{array}$ & N-P & & $\begin{array}{c}\text { Primar } \\
\text { y }\end{array}$ & $\begin{array}{c}\text { Cortex } \\
\text { Dominant }\end{array}$ & $\begin{array}{c}\text { Dull- } \\
\text { Milk } \\
\mathrm{y}\end{array}$ & Opaque & Coarse & $\begin{array}{l}\text { Foliat } \\
\text { ed }\end{array}$ \\
\hline & $\begin{array}{l}\text { Naibor Soit } \\
\text { Kubwa F5B }\end{array}$ & $\begin{array}{l}\text { Qt } \\
\mathrm{z}\end{array}$ & $\begin{array}{l}\mathrm{G} \\
\mathrm{R} 1\end{array}$ & $\mathrm{~N}$ & $\mathrm{~N}$ & $\begin{array}{c}35.3 \\
4743 \\
5\end{array}$ & $\begin{array}{c}- \\
2.95 \\
8418\end{array}$ & $\begin{array}{l}1535 \\
.19\end{array}$ & $\begin{array}{c}288 . \\
41\end{array}$ & $72 * 48 * 42$ & $\begin{array}{l}5 \mathrm{~PB} 5 / 2- \\
5 \mathrm{~PB} 7 / 2\end{array}$ & $\begin{array}{c}\text { Homogen } \\
\text { eous }\end{array}$ & N-P & & $\begin{array}{c}\text { Primar } \\
\text { y }\end{array}$ & $\begin{array}{c}\text { Fully } \\
\text { Cortical }\end{array}$ & $\begin{array}{c}\text { Milk } \\
\mathrm{y}\end{array}$ & Opaque & Coarse-Medium & $\begin{array}{l}\text { Foliat } \\
\text { ed }\end{array}$ \\
\hline & $\begin{array}{l}\text { Naibor Soit } \\
\text { Kubwa F5C }\end{array}$ & $\begin{array}{l}\text { Qt } \\
\mathrm{z}\end{array}$ & R3 & $\mathrm{N}$ & $\mathrm{N}$ & $\begin{array}{c}35.3 \\
4743 \\
8 \\
\end{array}$ & $\begin{array}{c}- \\
2.95 \\
8418 \\
\end{array}$ & $\begin{array}{l}1535 \\
.05\end{array}$ & $\begin{array}{c}165 . \\
20\end{array}$ & $73 * 50 * 30$ & $\begin{array}{c}5 \mathrm{YR} \\
6 / 4-5 \mathrm{R} \\
4 / 2 \\
\end{array}$ & $\begin{array}{c}\text { Homogen } \\
\text { eous }\end{array}$ & N-P & & $\begin{array}{c}\text { Primar } \\
\text { y }\end{array}$ & $\begin{array}{c}\text { Fully } \\
\text { Cortical }\end{array}$ & Dull & Opaque & Very Coarse & $\begin{array}{c}\begin{array}{l}\text { Non- } \\
\text { Foliat } \\
\text { ed }\end{array} \\
\end{array}$ \\
\hline & $\begin{array}{l}\text { Naibor Soit } \\
\text { Kubwa F6A }\end{array}$ & $\begin{array}{l}\text { Qt } \\
\mathrm{z}\end{array}$ & $\begin{array}{c}\mathrm{G} \\
\mathrm{R} 1\end{array}$ & $\mathrm{~N}$ & $\mathrm{~N}$ & $\begin{array}{c}35.3 \\
4807 \\
2 \\
\end{array}$ & $\begin{array}{c}- \\
2.96 \\
1217 \\
\end{array}$ & $\begin{array}{c}1572 \\
.7\end{array}$ & $\begin{array}{c}288 . \\
92\end{array}$ & $\begin{array}{c}123 * 58 * 3 \\
2\end{array}$ & $\begin{array}{l}5 \mathrm{~PB} 5 / 2- \\
5 \mathrm{~PB} 7 / 2\end{array}$ & $\begin{array}{c}\text { Homogen } \\
\text { eous }\end{array}$ & N-P & & $\begin{array}{c}\text { Primar } \\
\mathrm{y}\end{array}$ & $\begin{array}{l}\text { Fully } \\
\text { Cortical }\end{array}$ & $\begin{array}{c}\text { Milk } \\
\mathrm{y}\end{array}$ & Opaque & Coarse-Medium & $\begin{array}{l}\text { Foliat } \\
\text { ed }\end{array}$ \\
\hline & $\begin{array}{l}\text { Naibor Soit } \\
\text { Kubwa F6B }\end{array}$ & $\begin{array}{l}\text { Qt } \\
\mathrm{z}\end{array}$ & G1 & $\mathrm{N}$ & $\mathrm{N}$ & $\begin{array}{c}35.3 \\
4807 \\
3\end{array}$ & $\begin{array}{l}- \\
2.96 \\
1215\end{array}$ & $\begin{array}{l}1573 \\
.37\end{array}$ & $\begin{array}{c}192 . \\
70\end{array}$ & $71 * 42 * 38$ & $5 \mathrm{GY} 8 / 1$ & $\begin{array}{c}\text { Homogen } \\
\text { eous }\end{array}$ & N-P & & $\begin{array}{c}\text { Primar } \\
y\end{array}$ & $\begin{array}{c}\text { Fully } \\
\text { Cortical }\end{array}$ & Dull & Opaque & Coarse-Medium & $\begin{array}{c}\text { Foliat } \\
\text { ed }\end{array}$ \\
\hline & $\begin{array}{l}\text { Naibor Soit } \\
\text { Kubwa F6C }\end{array}$ & $\begin{array}{l}\text { Qt } \\
\mathrm{z}\end{array}$ & G1 & $\mathrm{N}$ & $\mathrm{N}$ & $\begin{array}{c}35.3 \\
4806 \\
6 \\
\end{array}$ & $\begin{array}{l}2.96 \\
121 \\
\end{array}$ & $\begin{array}{l}1573 \\
.56\end{array}$ & $\begin{array}{c}223 . \\
88\end{array}$ & $79 * 73 * 21$ & $5 \mathrm{GY} 8 / 1$ & $\begin{array}{c}\text { Homogen } \\
\text { eous }\end{array}$ & N-P & & $\begin{array}{c}\text { Primar } \\
\mathrm{y}\end{array}$ & $\begin{array}{c}\text { Fully } \\
\text { Cortical }\end{array}$ & Dull & Opaque & Coarse-Medium & $\begin{array}{c}\text { Foliat } \\
\text { ed }\end{array}$ \\
\hline & $\begin{array}{l}\text { Naibor Soit } \\
\text { Kubwa F6D }\end{array}$ & $\begin{array}{l}\text { Qt } \\
\mathrm{z}\end{array}$ & $\mathrm{R} 4$ & $\mathrm{~N}$ & $\mathrm{~N}$ & $\begin{array}{c}35.3 \\
4806 \\
2 \\
\end{array}$ & $\begin{array}{c}- \\
2.96 \\
1211 \\
\end{array}$ & $\begin{array}{l}1574 \\
.49\end{array}$ & $\begin{array}{c}234 . \\
03\end{array}$ & $93 * 64 * 54$ & $\begin{array}{c}5 \mathrm{YR} \\
6 / 4-5 \mathrm{YR} \\
5 / 6 \\
\end{array}$ & $\begin{array}{c}\text { Homogen } \\
\text { eous }\end{array}$ & N-P & & $\begin{array}{c}\text { Primar } \\
\text { y }\end{array}$ & $\begin{array}{l}\text { Fully } \\
\text { Cortical }\end{array}$ & Dull & Opaque & $\begin{array}{l}\text { Very Coarse } \\
\text { (Uncons.) }\end{array}$ & $\begin{array}{c}\text { Non- } \\
\text { Foliat } \\
\text { ed }\end{array}$ \\
\hline & $\begin{array}{l}\text { Naibor Soit } \\
\text { Kubwa F7A }\end{array}$ & $\begin{array}{l}\text { Qt } \\
\mathrm{z}\end{array}$ & $\mathrm{R} 1$ & $\mathrm{~N}$ & $\mathrm{~N}$ & $\begin{array}{c}35.3 \\
4567 \\
1\end{array}$ & $\begin{array}{l}- \\
2.95 \\
934\end{array}$ & $\begin{array}{l}1593 \\
.17\end{array}$ & $\begin{array}{c}397 . \\
54\end{array}$ & $\begin{array}{c}109 * 58 * 5 \\
1\end{array}$ & $\begin{array}{c}5 \mathrm{YR} \\
6 / 4-5 \mathrm{YR} \\
5 / 6\end{array}$ & $\begin{array}{c}\text { Homogen } \\
\text { eous }\end{array}$ & N-P & & $\begin{array}{c}\text { Primar } \\
\mathrm{y}\end{array}$ & $\begin{array}{c}\text { Fully } \\
\text { Cortical }\end{array}$ & Dull & Opaque & Coarse & $\begin{array}{c}\text { Non- } \\
\text { Foliat } \\
\text { ed }\end{array}$ \\
\hline
\end{tabular}




\begin{tabular}{|c|c|c|c|c|c|c|c|c|c|c|c|c|c|c|c|c|c|c|c|c|}
\hline Outcrop & Sample ID & $\begin{array}{l}\mathbf{R} \\
\mathbf{o c} \\
\mathbf{k} \\
\end{array}$ & $\begin{array}{l}\mathbf{R} \\
\mathbf{M} \\
\mathbf{G} \\
\end{array}$ & $\begin{array}{c}\text { ED } \\
\text { XR } \\
\text { F } \\
\end{array}$ & $\begin{array}{c}\begin{array}{c}\text { Petro } \\
\text { graph } \\
\mathbf{y}\end{array} \\
\end{array}$ & $\begin{array}{l}\text { Lon } \\
\text { g. }\end{array}$ & Lat. & Alt. & $\begin{array}{l}\text { Mas } \\
\text { s (g) }\end{array}$ & $\begin{array}{c}\text { Size } \\
\text { (mm; } \\
\text { LxWxT) }\end{array}$ & $\begin{array}{l}\text { Munsell } \\
\text { Code }\end{array}$ & $\begin{array}{l}\text { Striping } \\
\text { Zonation }\end{array}$ & Patina & Patina Color & $\begin{array}{c}\text { Corte } \\
\text { x } \\
\text { Type } \\
\end{array}$ & $\begin{array}{c}\text { Cortex } \\
\text { Proportio } \\
\text { n }\end{array}$ & Gloss & $\begin{array}{c}\text { Transpa } \\
\text { rency }\end{array}$ & Grain Size & $\begin{array}{c}\text { Foliat } \\
\text { ion }\end{array}$ \\
\hline & $\begin{array}{l}\text { Naibor Soit } \\
\text { Kubwa F7B }\end{array}$ & $\begin{array}{l}\mathrm{Qt} \\
\mathrm{z}\end{array}$ & R3 & $\mathrm{N}$ & $\mathrm{N}$ & $\begin{array}{l}35.3 \\
457\end{array}$ & $\begin{array}{c}- \\
2.95 \\
9321\end{array}$ & $\begin{array}{l}1595 \\
.17\end{array}$ & $\begin{array}{c}349 . \\
34\end{array}$ & $94 * 92 * 31$ & $\begin{array}{c}5 \mathrm{YR} \\
6 / 4-5 \mathrm{R} \\
4 / 2\end{array}$ & $\begin{array}{l}\text { Homogen } \\
\text { eous }\end{array}$ & N-P & & $\begin{array}{c}\text { Primar } \\
\mathrm{y}\end{array}$ & $\begin{array}{c}\text { Cortex } \\
\text { Dominant }\end{array}$ & $\begin{array}{c}\text { Milk } \\
\text { y }\end{array}$ & Opaque & Very Coarse & $\begin{array}{l}\begin{array}{l}\text { Non- } \\
\text { Foliat } \\
\text { ed }\end{array}\end{array}$ \\
\hline & $\begin{array}{l}\text { Naibor Soit } \\
\text { Kubwa F8A }\end{array}$ & $\begin{array}{l}\mathrm{Qt} \\
\mathrm{z}\end{array}$ & $\mathrm{R} 4$ & $\mathrm{~N}$ & $\mathrm{~N}$ & $\begin{array}{c}35.3 \\
4731 \\
1 \\
\end{array}$ & $\begin{array}{l}- \\
2.96 \\
1912 \\
\end{array}$ & $\begin{array}{c}1608 \\
.05\end{array}$ & $\begin{array}{c}193 . \\
89\end{array}$ & $\begin{array}{c}102 * 57 * 2 \\
8\end{array}$ & $\begin{array}{c}5 \mathrm{YR} \\
6 / 4-5 \mathrm{YR} \\
5 / 6\end{array}$ & $\begin{array}{c}\text { Homogen } \\
\text { eous }\end{array}$ & N-P & & $\begin{array}{c}\text { Primar } \\
\text { y }\end{array}$ & $\begin{array}{c}\text { Cortex } \\
\text { Dominant }\end{array}$ & Dull & Opaque & Very Coarse & $\begin{array}{c}\text { Non- } \\
\text { Foliat } \\
\text { ed }\end{array}$ \\
\hline & $\begin{array}{l}\text { Naibor Soit } \\
\text { Kubwa F9A }\end{array}$ & $\begin{array}{l}\text { Qt } \\
\mathrm{z}\end{array}$ & R1 & $\mathrm{N}$ & $\mathrm{N}$ & $\begin{array}{c}35.3 \\
4735 \\
8 \\
\end{array}$ & $\begin{array}{r}- \\
2.96 \\
3064 \\
\end{array}$ & $\begin{array}{l}1557 \\
.12\end{array}$ & $\begin{array}{c}255 . \\
47\end{array}$ & $76 * 70 * 46$ & $\begin{array}{c}5 \mathrm{YR} \\
6 / 4-5 \mathrm{YR} \\
5 / 6 \\
\end{array}$ & $\begin{array}{c}\text { Homogen } \\
\text { eous }\end{array}$ & N-P & & $\begin{array}{c}\text { Primar } \\
\text { y }\end{array}$ & $\begin{array}{l}\text { Fully } \\
\text { Cortical }\end{array}$ & Dull & Opaque & Coarse & $\begin{array}{c}\begin{array}{c}\text { Non- } \\
\text { Foliat } \\
\text { ed }\end{array} \\
\end{array}$ \\
\hline & $\begin{array}{l}\text { Naibor Soit } \\
\text { Kubwa F9B } \\
\end{array}$ & $\begin{array}{l}\text { Qt } \\
\mathrm{z}\end{array}$ & $\begin{array}{l}\mathrm{W} \\
1\end{array}$ & $\mathrm{~N}$ & $\mathrm{~N}$ & $\begin{array}{l}35.3 \\
4736 \\
\end{array}$ & $\begin{array}{r}- \\
2.96 \\
3075 \\
\end{array}$ & $\begin{array}{l}1557 \\
.75\end{array}$ & $\begin{array}{c}339 . \\
14\end{array}$ & $\begin{array}{c}105 * 65 * 4 \\
7\end{array}$ & $\begin{array}{c}\mathrm{N} 8-5 \mathrm{Y} \\
8 / 1 \\
\end{array}$ & $\begin{array}{c}\text { Homogen } \\
\text { eous }\end{array}$ & N-P & & $\begin{array}{c}\text { Primar } \\
\text { y }\end{array}$ & $\begin{array}{c}\text { Cortex } \\
\text { Dominant }\end{array}$ & $\begin{array}{c}\text { Dull- } \\
\text { Milk } \\
\mathrm{y}\end{array}$ & Opaque & Coarse & $\begin{array}{c}\begin{array}{c}\text { Foliat } \\
\text { ed }\end{array} \\
\end{array}$ \\
\hline & $\begin{array}{c}\text { Naibor Soit } \\
\text { Kubwa } \\
\text { G10A }\end{array}$ & $\begin{array}{l}\text { Qt } \\
\mathrm{z}\end{array}$ & $\mathrm{R} 4$ & $\mathrm{~N}$ & $\mathrm{~N}$ & $\begin{array}{c}35.3 \\
4747 \\
2 \\
\end{array}$ & $\begin{array}{r}- \\
2.96 \\
3825 \\
\end{array}$ & $\begin{array}{l}1558 \\
.18\end{array}$ & $\begin{array}{l}291 . \\
05\end{array}$ & $79 * 69 * 49$ & $\begin{array}{c}5 \mathrm{YR} \\
6 / 4-5 \mathrm{YR} \\
5 / 6\end{array}$ & $\begin{array}{c}\text { Homogen } \\
\text { eous }\end{array}$ & $\begin{array}{c}\text { Patina } \\
\text { Dominant }\end{array}$ & $\begin{array}{c}10 \text { YR } 8 / 2 \\
\text { (Very Pale } \\
\text { Orange) }\end{array}$ & $\begin{array}{c}\text { Primar } \\
\mathrm{y}\end{array}$ & $\begin{array}{c}\text { Fully } \\
\text { Cortical }\end{array}$ & Dull & Opaque & Very Coarse & $\begin{array}{c}\text { Non- } \\
\text { Foliat } \\
\text { ed }\end{array}$ \\
\hline & $\begin{array}{c}\text { Naibor Soit } \\
\text { Kubwa } \\
\text { G10B }\end{array}$ & $\begin{array}{l}\text { Qt } \\
\mathrm{z}\end{array}$ & $\begin{array}{l}\text { W } \\
3\end{array}$ & $\mathrm{~N}$ & $\mathrm{~N}$ & $\begin{array}{c}35.3 \\
4746 \\
3 \\
\end{array}$ & $\begin{array}{r}- \\
2.96 \\
3851 \\
\end{array}$ & $\begin{array}{l}1560 \\
.16\end{array}$ & $\begin{array}{l}310 . \\
30\end{array}$ & $\begin{array}{c}121 * 73 * 3 \\
5\end{array}$ & N9 & $\begin{array}{c}\text { Homogen } \\
\text { eous }\end{array}$ & N-P & & $\begin{array}{c}\text { Primar } \\
\text { y }\end{array}$ & $\begin{array}{c}\text { Cortex } \\
\text { Dominant }\end{array}$ & $\begin{array}{c}\text { Dull- } \\
\text { Milk } \\
\mathrm{y}\end{array}$ & Opaque & Very Coarse & $\begin{array}{c}\begin{array}{c}\text { Non- } \\
\text { Foliat } \\
\text { ed }\end{array} \\
\end{array}$ \\
\hline & $\begin{array}{c}\text { Naibor Soit } \\
\text { Kubwa } \\
\text { G10C }\end{array}$ & $\begin{array}{l}\text { Qt } \\
\mathrm{z}\end{array}$ & R3 & $\mathrm{N}$ & $\mathrm{N}$ & $\begin{array}{c}35.3 \\
4748 \\
1 \\
\end{array}$ & $\begin{array}{r}- \\
2.96 \\
3832 \\
\end{array}$ & $\begin{array}{l}1562 \\
.27\end{array}$ & $\begin{array}{c}284 . \\
07\end{array}$ & $83 * 82 * 49$ & $\begin{array}{c}5 \mathrm{YR} \\
6 / 4-5 \mathrm{R} \\
4 / 2 \\
\end{array}$ & $\begin{array}{c}\text { Homogen } \\
\text { eous }\end{array}$ & N-P & & $\begin{array}{c}\text { Primar } \\
\text { y }\end{array}$ & $\begin{array}{c}\text { Cortex } \\
\text { Dominant }\end{array}$ & $\begin{array}{c}\text { Milk } \\
\mathrm{y}\end{array}$ & Opaque & Very Coarse & $\begin{array}{c}\text { Non- } \\
\text { Foliat } \\
\text { ed }\end{array}$ \\
\hline & $\begin{array}{c}\text { Naibor Soit } \\
\text { Kubwa G6A }\end{array}$ & $\begin{array}{l}\text { Qt } \\
\mathrm{z}\end{array}$ & $\begin{array}{l}\mathrm{G} \\
\mathrm{R} 1\end{array}$ & $\mathrm{~N}$ & $\mathrm{~N}$ & $\begin{array}{c}35.3 \\
4804 \\
3 \\
\end{array}$ & $\begin{array}{l}- \\
2.96 \\
077 \\
\end{array}$ & $\begin{array}{c}1563 \\
.64\end{array}$ & $\begin{array}{l}197 . \\
25\end{array}$ & $78 * 52 * 50$ & $\begin{array}{l}5 \mathrm{~PB} 5 / 2- \\
5 \mathrm{~PB} 7 / 2\end{array}$ & $\begin{array}{c}\text { Homogen } \\
\text { eous }\end{array}$ & N-P & & $\begin{array}{c}\text { Primar } \\
y\end{array}$ & $\begin{array}{c}\text { Fully } \\
\text { Cortical }\end{array}$ & $\begin{array}{c}\text { Milk } \\
\mathrm{y}\end{array}$ & Opaque & Coarse-Medium & $\begin{array}{l}\text { Foliat } \\
\text { ed }\end{array}$ \\
\hline & $\begin{array}{l}\text { Naibor Soit } \\
\text { Kubwa G6D }\end{array}$ & $\begin{array}{l}\text { Qt } \\
\mathrm{z}\end{array}$ & $\begin{array}{l}\mathrm{W} \\
2\end{array}$ & $\mathrm{~N}$ & $\mathrm{~N}$ & $\begin{array}{l}35.3 \\
4806 \\
\end{array}$ & $\begin{array}{l}2.96 \\
0773\end{array}$ & $\begin{array}{c}1564 \\
.1\end{array}$ & $\begin{array}{l}>50 \\
0.00\end{array}$ & $96 * 95 * 38$ & $5 \mathrm{YR} 8 / 1$ & Zoned & N-P & & $\begin{array}{c}\text { Primar } \\
y\end{array}$ & $\begin{array}{c}\text { Fully } \\
\text { Cortical }\end{array}$ & $\begin{array}{c}\text { Dull- } \\
\text { Milk } \\
\mathrm{y}\end{array}$ & Opaque & Coarse & $\begin{array}{l}\text { Non- } \\
\text { Foliat } \\
\text { ed }\end{array}$ \\
\hline & $\begin{array}{l}\text { Naibor Soit } \\
\text { Kubwa G9A }\end{array}$ & $\begin{array}{l}\text { Qt } \\
\mathrm{z}\end{array}$ & $\mathrm{R} 2$ & $\mathrm{~N}$ & $\mathrm{Y}$ & $\begin{array}{c}35.3 \\
4837 \\
7\end{array}$ & $\begin{array}{c}- \\
2.96 \\
3464\end{array}$ & $\begin{array}{l}1607 \\
.63\end{array}$ & $\begin{array}{c}381 . \\
32\end{array}$ & $\begin{array}{c}121 * 71 * 3 \\
8\end{array}$ & $\begin{array}{c}5 \mathrm{YR} \\
6 / 4-5 \mathrm{R} \\
4 / 2\end{array}$ & $\begin{array}{c}\text { Homogen } \\
\text { eous }\end{array}$ & N-P & & $\begin{array}{c}\text { Primar } \\
\text { y }\end{array}$ & $\begin{array}{c}\text { Cortex } \\
\text { Dominant }\end{array}$ & $\begin{array}{c}\text { Milk } \\
\text { y }\end{array}$ & Opaque & Coarse & $\begin{array}{l}\text { Foliat } \\
\text { ed }\end{array}$ \\
\hline & $\begin{array}{c}\text { Naibor Soit } \\
\text { Kubwa } \\
\text { H10A } \\
\end{array}$ & $\begin{array}{l}\text { Qt } \\
\mathrm{z}\end{array}$ & $\begin{array}{l}\mathrm{G} \\
\mathrm{R} 1\end{array}$ & $\mathrm{~N}$ & $\mathrm{~N}$ & $\begin{array}{l}35.3 \\
4891\end{array}$ & $\begin{array}{c}- \\
2.96 \\
3749 \\
\end{array}$ & $\begin{array}{l}1582 \\
.36\end{array}$ & $\begin{array}{c}429 . \\
22\end{array}$ & $95 * 62 * 37$ & $\begin{array}{l}5 \mathrm{~PB} 5 / 2- \\
5 \mathrm{~PB} 7 / 2 \\
\end{array}$ & $\begin{array}{l}\text { Homogen } \\
\text { eous }\end{array}$ & N-P & & $\begin{array}{c}\text { Primar } \\
\text { y }\end{array}$ & $\begin{array}{c}\text { Cortex } \\
\text { Dominant }\end{array}$ & $\begin{array}{c}\text { Milk } \\
\text { y }\end{array}$ & Opaque & Coarse-Medium & $\begin{array}{c}\text { Foliat } \\
\text { ed }\end{array}$ \\
\hline & $\begin{array}{c}\text { Naibor Soit } \\
\text { Kubwa } \\
\text { H10B } \\
\end{array}$ & $\begin{array}{l}\mathrm{Qt} \\
\mathrm{z}\end{array}$ & R3 & $\mathrm{N}$ & $\mathrm{N}$ & $\begin{array}{l}35.3 \\
4893 \\
\end{array}$ & $\begin{array}{c}- \\
2.96 \\
3754 \\
\end{array}$ & $\begin{array}{c}1583 \\
.75\end{array}$ & $\begin{array}{l}>50 \\
0.00\end{array}$ & $85 * 66 * 64$ & $\begin{array}{c}5 \mathrm{YR} \\
6 / 4-5 \mathrm{R} \\
4 / 2 \\
\end{array}$ & $\begin{array}{c}\text { Homogen } \\
\text { eous }\end{array}$ & N-P & & $\begin{array}{c}\text { Primar } \\
\text { y }\end{array}$ & $\begin{array}{c}\text { Cortex } \\
\text { Dominant }\end{array}$ & $\begin{array}{c}\text { Milk } \\
\text { y }\end{array}$ & Opaque & Very Coarse & $\begin{array}{l}\text { Foliat } \\
\text { ed }\end{array}$ \\
\hline & $\begin{array}{c}\text { Naibor Soit } \\
\text { Kubwa } \\
\text { H12A }\end{array}$ & $\begin{array}{l}\text { Qt } \\
\mathrm{z}\end{array}$ & R3 & $\mathrm{N}$ & $\mathrm{N}$ & $\begin{array}{c}35.3 \\
4943 \\
3\end{array}$ & $\begin{array}{l}-\overline{-} \\
6538\end{array}$ & $\begin{array}{l}1545 \\
.45\end{array}$ & $\begin{array}{l}>50 \\
0.00\end{array}$ & $90 * 89 * 44$ & $\begin{array}{c}5 \mathrm{YR} \\
6 / 4-5 \mathrm{R} \\
4 / 2\end{array}$ & $\begin{array}{c}\text { Homogen } \\
\text { eous }\end{array}$ & N-P & & $\begin{array}{c}\text { Primar } \\
\text { y }\end{array}$ & $\begin{array}{c}\text { Fully } \\
\text { Cortical }\end{array}$ & $\begin{array}{c}\text { Milk } \\
\text { y }\end{array}$ & Opaque & $\begin{array}{c}\text { Very Coarse } \\
\text { (partially } \\
\text { uncons.) }\end{array}$ & $\begin{array}{l}\text { Non- } \\
\text { Foliat } \\
\text { ed }\end{array}$ \\
\hline & $\begin{array}{c}\text { Naibor Soit } \\
\text { Kubwa } \\
\text { H12B }\end{array}$ & $\begin{array}{l}\text { Qt } \\
\mathrm{z}\end{array}$ & R3 & $\mathrm{N}$ & $\mathrm{N}$ & $\begin{array}{c}35.3 \\
4942 \\
9 \\
\end{array}$ & $\begin{array}{r}- \\
2.96 \\
6535 \\
\end{array}$ & $\begin{array}{l}1547 \\
.15\end{array}$ & $\begin{array}{l}>50 \\
0.00\end{array}$ & $75 * 68 * 55$ & $\begin{array}{c}5 \mathrm{YR} \\
6 / 4-5 \mathrm{R} \\
4 / 2 \\
\end{array}$ & $\begin{array}{c}\text { Homogen } \\
\text { eous }\end{array}$ & N-P & & $\begin{array}{c}\text { Primar } \\
\mathrm{y}\end{array}$ & $\begin{array}{c}\text { Cortex } \\
\text { Dominant }\end{array}$ & $\begin{array}{c}\text { Milk } \\
\text { y }\end{array}$ & Opaque & Very Coarse & $\begin{array}{l}\begin{array}{c}\text { Non- } \\
\text { Foliat } \\
\text { ed }\end{array} \\
\end{array}$ \\
\hline & $\begin{array}{c}\text { Naibor Soit } \\
\text { Kubwa I10B }\end{array}$ & $\begin{array}{l}\mathrm{Qt} \\
\mathrm{z}\end{array}$ & $\begin{array}{l}\text { W } \\
3\end{array}$ & $\mathrm{~N}$ & $\mathrm{~N}$ & $\begin{array}{c}35.3 \\
4920 \\
3 \\
\end{array}$ & $\begin{array}{c}- \\
2.96 \\
3771 \\
\end{array}$ & $\begin{array}{l}1571 \\
.74\end{array}$ & $\begin{array}{c}245 . \\
91\end{array}$ & $73 * 51 * 40$ & N9 & $\begin{array}{c}\text { Homogen } \\
\text { eous }\end{array}$ & N-P & & $\begin{array}{c}\text { Primar } \\
\mathrm{y}\end{array}$ & $\begin{array}{c}\text { Cortex } \\
\text { Dominant }\end{array}$ & $\begin{array}{c}\text { Milk } \\
\text { y }\end{array}$ & Opaque & Coarse & $\begin{array}{c}\begin{array}{c}\text { Non- } \\
\text { Foliat } \\
\text { ed }\end{array} \\
\end{array}$ \\
\hline & $\begin{array}{l}\text { Naibor Soit } \\
\text { Kubwa I10C }\end{array}$ & $\begin{array}{l}\text { Qt } \\
\mathrm{z}\end{array}$ & $\begin{array}{l}\text { W } \\
2\end{array}$ & $\mathrm{~N}$ & $\mathrm{~N}$ & $\begin{array}{c}35.3 \\
4919 \\
5\end{array}$ & $\begin{array}{l}- \\
2.96 \\
3768\end{array}$ & $\begin{array}{l}1570 \\
.58\end{array}$ & $\begin{array}{l}>50 \\
0.00\end{array}$ & $\begin{array}{c}127 * 114 * \\
57\end{array}$ & $5 \mathrm{G} 6 / 1$ & $\begin{array}{c}\text { Homogen } \\
\text { eous }\end{array}$ & N-P & & $\begin{array}{c}\text { Primar } \\
\mathrm{y}\end{array}$ & $\begin{array}{c}\text { Cortex } \\
\text { Dominant }\end{array}$ & $\begin{array}{c}\text { Milk } \\
\text { y }\end{array}$ & Opaque & Coarse & $\begin{array}{l}\text { Non- } \\
\text { Foliat } \\
\text { ed }\end{array}$ \\
\hline & $\begin{array}{l}\text { Naibor Soit } \\
\text { Kubwa I10D }\end{array}$ & $\begin{array}{l}\text { Qt } \\
\mathrm{z}\end{array}$ & $\begin{array}{l}\mathrm{G} \\
\mathrm{R} 1\end{array}$ & $\mathrm{~N}$ & $\mathrm{~N}$ & $\begin{array}{c}35.3 \\
4916 \\
5\end{array}$ & $\begin{array}{l}2.96 \\
3752\end{array}$ & $\begin{array}{c}1570 \\
.4\end{array}$ & $\begin{array}{l}>50 \\
0.00\end{array}$ & $\begin{array}{c}104 * 75 * 4 \\
9\end{array}$ & $\begin{array}{l}5 \mathrm{~PB} 5 / 2- \\
5 \mathrm{~PB} 7 / 2\end{array}$ & $\begin{array}{c}\text { Homogen } \\
\text { eous }\end{array}$ & N-P & & $\begin{array}{c}\text { Primar } \\
\mathrm{y}\end{array}$ & $\begin{array}{c}\text { Cortex } \\
\text { Dominant }\end{array}$ & $\begin{array}{c}\text { Milk } \\
\text { y }\end{array}$ & Opaque & Coarse-Medium & $\begin{array}{l}\text { Foliat } \\
\text { ed }\end{array}$ \\
\hline & $\begin{array}{c}\text { Naibor Soit } \\
\text { Kubwa I11B }\end{array}$ & $\begin{array}{l}\text { Qt } \\
\mathrm{z}\end{array}$ & R1 & $\mathrm{N}$ & $\mathrm{N}$ & $\begin{array}{c}35.3 \\
4940 \\
9 \\
\end{array}$ & $\begin{array}{c}- \\
2.96 \\
4755 \\
\end{array}$ & $\begin{array}{l}1569 \\
.26\end{array}$ & $\begin{array}{c}380 . \\
11\end{array}$ & $86 * 73 * 29$ & $\begin{array}{c}5 \mathrm{YR} \\
6 / 4-5 \mathrm{YR} \\
5 / 6 \\
\end{array}$ & $\begin{array}{c}\text { Homogen } \\
\text { eous }\end{array}$ & N-P & & $\begin{array}{c}\text { Primar } \\
\text { y }\end{array}$ & $\begin{array}{l}\text { Fully } \\
\text { Cortical }\end{array}$ & $\begin{array}{c}\text { Milk } \\
\text { y }\end{array}$ & Opaque & Very Coarse & $\begin{array}{c}\text { Foliat } \\
\text { ed }\end{array}$ \\
\hline & $\begin{array}{l}\text { Naibor Soit } \\
\text { Kubwa I11C }\end{array}$ & $\begin{array}{l}\text { Qt } \\
\mathrm{z}\end{array}$ & $\begin{array}{l}\mathrm{G} \\
\mathrm{R} 1\end{array}$ & $\mathrm{~N}$ & $\mathrm{~N}$ & $\begin{array}{c}35.3 \\
4939 \\
1\end{array}$ & $\begin{array}{l}- \\
2.96 \\
4757\end{array}$ & $\begin{array}{l}1569 \\
.62\end{array}$ & $\begin{array}{l}>50 \\
0.00\end{array}$ & $\begin{array}{c}117 * 54 * 5 \\
0\end{array}$ & $\begin{array}{l}5 \text { PB 5/2- } \\
5 \mathrm{~PB} 7 / 2\end{array}$ & $\begin{array}{c}\text { Homogen } \\
\text { eous }\end{array}$ & N-P & & $\begin{array}{c}\text { Primar } \\
\mathrm{y}\end{array}$ & $\begin{array}{c}\text { Cortex } \\
\text { Dominant }\end{array}$ & $\begin{array}{c}\text { Milk } \\
\text { y }\end{array}$ & Opaque & Very Coarse & $\begin{array}{c}\text { Non- } \\
\text { Foliat } \\
\text { ed }\end{array}$ \\
\hline
\end{tabular}




\begin{tabular}{|c|c|c|c|c|c|c|c|c|c|c|c|c|c|c|c|c|c|c|c|c|}
\hline Outcrop & Sample ID & $\begin{array}{l}\mathbf{R} \\
\mathbf{o c} \\
\mathbf{k} \\
\end{array}$ & $\begin{array}{l}\mathbf{R} \\
\mathbf{M} \\
\mathbf{G} \\
\end{array}$ & $\begin{array}{c}\text { ED } \\
\text { XR } \\
\text { F } \\
\end{array}$ & $\begin{array}{c}\begin{array}{c}\text { Petro } \\
\text { graph } \\
\text { y }\end{array} \\
\end{array}$ & $\begin{array}{c}\text { Lon } \\
\text { g. }\end{array}$ & Lat. & Alt. & $\begin{array}{l}\text { Mas } \\
\text { s (g) }\end{array}$ & $\begin{array}{c}\text { Size } \\
\text { (mm; } \\
\text { LxWxT) }\end{array}$ & $\begin{array}{l}\text { Munsell } \\
\text { Code }\end{array}$ & $\begin{array}{l}\text { Striping } \\
\text { Zonation }\end{array}$ & Patina & Patina Color & $\begin{array}{c}\text { Corte } \\
x \\
\text { Type } \\
\end{array}$ & $\begin{array}{c}\text { Cortex } \\
\text { Proportio } \\
\text { n } \\
\end{array}$ & Gloss & $\begin{array}{c}\text { Transpa } \\
\text { rency }\end{array}$ & Grain Size & $\begin{array}{c}\text { Foliat } \\
\text { ion }\end{array}$ \\
\hline & $\begin{array}{l}\text { Naibor Soit } \\
\text { Kubwa I12A }\end{array}$ & $\begin{array}{l}\mathrm{Qt} \\
\mathrm{z}\end{array}$ & $\mathrm{R} 4$ & $\mathrm{~N}$ & $\mathrm{~N}$ & $\begin{array}{c}35.3 \\
4993 \\
3 \\
\end{array}$ & $\begin{array}{l}2.96 \\
6197 \\
\end{array}$ & $\begin{array}{l}1547 \\
.41\end{array}$ & $\begin{array}{l}>50 \\
0.00\end{array}$ & $\begin{array}{c}129 * 79 * 5 \\
1\end{array}$ & $\begin{array}{c}5 \mathrm{YR} \\
6 / 4-5 \mathrm{YR} \\
5 / 6 \\
\end{array}$ & $\begin{array}{l}\text { Homogen } \\
\text { eous }\end{array}$ & N-P & & $\begin{array}{c}\text { Primar } \\
\mathrm{y}\end{array}$ & $\begin{array}{c}\text { Cortex } \\
\text { Dominant }\end{array}$ & Dull & Opaque & $\begin{array}{l}\text { Very Coarse } \\
\text { (Uncons.) }\end{array}$ & $\begin{array}{c}\text { Non- } \\
\text { Foliat } \\
\text { ed } \\
\end{array}$ \\
\hline & $\begin{array}{c}\text { Naibor Soit } \\
\text { Kubwa I12B }\end{array}$ & $\begin{array}{l}\text { Qt } \\
\mathrm{z}\end{array}$ & R3 & $\mathrm{N}$ & $\mathrm{N}$ & $\begin{array}{c}35.3 \\
4993 \\
3 \\
\end{array}$ & $\begin{array}{l}2.96 \\
6197 \\
\end{array}$ & $\begin{array}{c}1547 \\
.41\end{array}$ & $\begin{array}{c}209 . \\
90\end{array}$ & $91 * 54 * 34$ & $\begin{array}{c}5 \mathrm{YR} \\
6 / 4-5 \mathrm{R} \\
4 / 2 \\
\end{array}$ & $\begin{array}{l}\text { Homogen } \\
\text { eous }\end{array}$ & N-P & & $\begin{array}{c}\text { Primar } \\
\mathrm{y}\end{array}$ & $\begin{array}{c}\text { Cortex } \\
\text { Dominant }\end{array}$ & $\begin{array}{c}\text { Milk } \\
\text { y }\end{array}$ & Opaque & Very Coarse & $\begin{array}{l}\text { Non- } \\
\text { Foliat } \\
\text { ed }\end{array}$ \\
\hline & $\begin{array}{l}\text { Naibor Soit } \\
\text { Kubwa I9A }\end{array}$ & $\begin{array}{l}\text { Qt } \\
\mathrm{z}\end{array}$ & $\mathrm{R} 1$ & $\mathrm{~N}$ & $\mathrm{~N}$ & $\begin{array}{c}35.3 \\
4861 \\
5\end{array}$ & $\begin{array}{r}- \\
2.96 \\
3073 \\
\end{array}$ & $\begin{array}{l}1582 \\
.81\end{array}$ & $\begin{array}{c}276 . \\
89\end{array}$ & $\begin{array}{c}100 * 64 * 3 \\
5\end{array}$ & $\begin{array}{c}5 \mathrm{YR} \\
6 / 4-5 \mathrm{YR} \\
5 / 6\end{array}$ & $\begin{array}{l}\text { Homogen } \\
\text { eous }\end{array}$ & N-P & & $\begin{array}{c}\text { Primar } \\
\text { y }\end{array}$ & $\begin{array}{l}\text { Fully } \\
\text { Cortical }\end{array}$ & $\begin{array}{c}\text { Milk } \\
\text { y }\end{array}$ & Opaque & Very Coarse & $\begin{array}{l}\text { Non- } \\
\text { Foliat } \\
\text { ed }\end{array}$ \\
\hline & $\begin{array}{r}\text { Naibor Soit } \\
\text { Kubwa J12A }\end{array}$ & $\begin{array}{l}\text { Qt } \\
\mathrm{z}\end{array}$ & $\mathrm{R} 4$ & $\mathrm{~N}$ & $\mathrm{~N}$ & $\begin{array}{l}35.3 \\
5084 \\
\end{array}$ & $\begin{array}{l}2.96 \\
6152 \\
\end{array}$ & $\begin{array}{l}1548 \\
.54\end{array}$ & $\begin{array}{c}335 . \\
73\end{array}$ & $83 * 79 * 41$ & $\begin{array}{c}5 \mathrm{YR} \\
6 / 4-5 \mathrm{YR} \\
5 / 6 \\
\end{array}$ & $\begin{array}{l}\text { Homogen } \\
\text { eous }\end{array}$ & $\begin{array}{c}\text { Patina } \\
\text { Dominant }\end{array}$ & $\begin{array}{c}10 \mathrm{YR} 8 / 2 \\
\text { (Very Pale } \\
\text { Orange) }\end{array}$ & $\begin{array}{c}\text { Primar } \\
\mathrm{y}\end{array}$ & $\begin{array}{c}\text { Cortex } \\
\text { Dominant }\end{array}$ & Dull & Opaque & Very Coarse & $\begin{array}{l}\text { Non- } \\
\text { Foliat } \\
\text { ed }\end{array}$ \\
\hline & $\begin{array}{c}\text { Naibor Soit } \\
\text { Kubwa } \\
\text { K12A }\end{array}$ & $\begin{array}{l}\text { Qt } \\
\mathrm{z}\end{array}$ & R3 & $\mathrm{N}$ & $\mathrm{N}$ & $\begin{array}{c}35.3 \\
5159 \\
8 \\
\end{array}$ & $\begin{array}{l}- \\
2.96 \\
6689\end{array}$ & 1556 & $\begin{array}{c}292 . \\
56\end{array}$ & $82 * 65 * 51$ & $\begin{array}{c}5 \mathrm{YR} \\
6 / 4-5 \mathrm{R} \\
4 / 2 \\
\end{array}$ & Zoned & N-P & & $\begin{array}{c}\text { Primar } \\
\text { y }\end{array}$ & $\begin{array}{c}\text { Cortex } \\
\text { Dominant }\end{array}$ & $\begin{array}{c}\text { Milk } \\
\text { y }\end{array}$ & Opaque & Coarse & $\begin{array}{c}\text { Non- } \\
\text { Foliat } \\
\text { ed }\end{array}$ \\
\hline & $\begin{array}{c}\text { Naibor Soit } \\
\text { Kubwa } \\
\text { K12B } \\
\end{array}$ & $\begin{array}{l}\text { Qt } \\
\mathrm{z}\end{array}$ & $\mathrm{R} 4$ & $\mathrm{~N}$ & $\mathrm{Y}$ & $\begin{array}{c}35.3 \\
5158 \\
5 \\
\end{array}$ & $\begin{array}{l}- \\
2.96 \\
6692 \\
\end{array}$ & $\begin{array}{c}1556 \\
.98\end{array}$ & $\begin{array}{l}371 . \\
27\end{array}$ & $83 * 57 * 56$ & $\begin{array}{c}5 \mathrm{YR} \\
6 / 4-5 \mathrm{YR} \\
5 / 6 \\
\end{array}$ & $\begin{array}{l}\text { Homogen } \\
\text { eous }\end{array}$ & N-P & & $\begin{array}{c}\text { Primar } \\
\mathrm{y}\end{array}$ & $\begin{array}{l}\text { Fully } \\
\text { Cortical }\end{array}$ & Dull & Opaque & $\begin{array}{l}\text { Very Coarse } \\
\text { (Uncons.) }\end{array}$ & $\begin{array}{c}\text { Foliat } \\
\text { ed }\end{array}$ \\
\hline & $\begin{array}{c}\text { Naibor Soit } \\
\text { Kubwa } \\
\text { K13B }\end{array}$ & $\begin{array}{l}\text { Qt } \\
\mathrm{z}\end{array}$ & $\begin{array}{l}\mathrm{W} \\
3\end{array}$ & $\mathrm{~N}$ & $\mathrm{~N}$ & $\begin{array}{c}35.3 \\
4710 \\
7\end{array}$ & $\begin{array}{l}2.96 \\
4326\end{array}$ & $\begin{array}{c}1539 \\
.1\end{array}$ & $\begin{array}{c}357 . \\
96\end{array}$ & $85^{*} 75^{*} 49$ & N9 & $\begin{array}{l}\text { Homogen } \\
\text { eous }\end{array}$ & N-P & & $\begin{array}{c}\text { Primar } \\
\text { y }\end{array}$ & $\begin{array}{l}\text { Fully } \\
\text { Cortical }\end{array}$ & $\begin{array}{c}\text { Dull- } \\
\text { Milk } \\
\text { y }\end{array}$ & Opaque & Coarse & $\begin{array}{c}\begin{array}{c}\text { Foliat } \\
\text { ed }\end{array} \\
\end{array}$ \\
\hline & $\begin{array}{c}\text { Naibor Soit } \\
\text { Kubwa } \\
\text { K13C } \\
\end{array}$ & $\begin{array}{l}\text { Qt } \\
\mathrm{z}\end{array}$ & $\begin{array}{c}\mathrm{W} \\
1\end{array}$ & $\mathrm{~N}$ & $\mathrm{~N}$ & $\begin{array}{c}35.3 \\
4710 \\
7 \\
\end{array}$ & $\begin{array}{r}- \\
2.96 \\
4329 \\
\end{array}$ & $\begin{array}{l}1539 \\
.93\end{array}$ & $\begin{array}{c}206 . \\
67\end{array}$ & $\begin{array}{c}102 * 58 * 2 \\
6\end{array}$ & $\begin{array}{c}\mathrm{N} 8-5 \mathrm{Y} \\
8 / 1\end{array}$ & $\begin{array}{l}\text { Homogen } \\
\text { eous }\end{array}$ & N-P & & $\begin{array}{c}\text { Primar } \\
\text { y }\end{array}$ & $\begin{array}{l}\text { Fully } \\
\text { Cortical }\end{array}$ & $\begin{array}{c}\text { Dull- } \\
\text { Milk } \\
\mathrm{y}\end{array}$ & Opaque & Coarse & $\begin{array}{c}\text { Foliat } \\
\text { ed }\end{array}$ \\
\hline & $\begin{array}{c}\text { Naibor Soit } \\
\text { Kubwa } \\
\text { K13D } \\
\end{array}$ & $\begin{array}{l}\text { Qt } \\
\mathrm{z}\end{array}$ & R3 & $\mathrm{N}$ & $\mathrm{N}$ & $\begin{array}{c}35.3 \\
4710 \\
7 \\
\end{array}$ & $\begin{array}{r}2.96 \\
4325 \\
\end{array}$ & $\begin{array}{l}1539 \\
.53\end{array}$ & $\begin{array}{c}401 . \\
38\end{array}$ & $88 * 84 * 48$ & $5 Y 8 / 1$ & $\begin{array}{l}\text { Homogen } \\
\text { eous }\end{array}$ & N-P & & $\begin{array}{c}\text { Primar } \\
\text { y }\end{array}$ & $\begin{array}{c}\text { Cortex } \\
\text { Dominant }\end{array}$ & $\begin{array}{c}\text { Milk } \\
\mathrm{y}\end{array}$ & Opaque & Very Coarse & $\begin{array}{l}\text { Non- } \\
\text { Foliat } \\
\text { ed } \\
\end{array}$ \\
\hline & $\begin{array}{c}\text { Naibor Soit } \\
\text { Kubwa } \\
\text { K15A }\end{array}$ & $\begin{array}{l}\text { Qt } \\
\mathrm{z}\end{array}$ & R3 & $\mathrm{N}$ & $\mathrm{N}$ & $\begin{array}{c}35.3 \\
5190 \\
9\end{array}$ & $\begin{array}{l}2.96 \\
9783\end{array}$ & $\begin{array}{l}1524 \\
.89\end{array}$ & $\begin{array}{c}401 . \\
38\end{array}$ & $88 * 84 * 48$ & $5 Y 8 / 1$ & $\begin{array}{l}\text { Homogen } \\
\text { eous }\end{array}$ & N-P & & $\begin{array}{c}\text { Primar } \\
\mathrm{y}\end{array}$ & $\begin{array}{l}\text { Fully } \\
\text { Cortical }\end{array}$ & $\begin{array}{c}\text { Milk } \\
\text { y }\end{array}$ & Opaque & Very Coarse & $\begin{array}{l}\text { Non- } \\
\text { Foliat } \\
\text { ed }\end{array}$ \\
\hline & $\begin{array}{c}\text { Naibor Soit } \\
\text { Kubwa } \\
\text { K15B } \\
\end{array}$ & $\begin{array}{l}\text { Qt } \\
\mathrm{z}\end{array}$ & R4 & $\mathrm{N}$ & $\mathrm{N}$ & $\begin{array}{c}35.3 \\
5192 \\
4 \\
\end{array}$ & $\begin{array}{r}- \\
2.96 \\
9796 \\
\end{array}$ & $\begin{array}{l}1523 \\
.85\end{array}$ & $\begin{array}{l}224 . \\
05\end{array}$ & $92 * 66 * 30$ & $\begin{array}{c}5 \mathrm{YR} \\
6 / 4-5 \mathrm{YR} \\
5 / 6 \\
\end{array}$ & $\begin{array}{l}\text { Homogen } \\
\text { eous }\end{array}$ & N-P & & $\begin{array}{c}\text { Primar } \\
\text { y }\end{array}$ & $\begin{array}{c}\text { Cortex } \\
\text { Dominant }\end{array}$ & Dull & Opaque & $\begin{array}{l}\text { Very Coarse } \\
\text { (Uncons.) }\end{array}$ & $\begin{array}{c}\text { Non- } \\
\text { Foliat } \\
\text { ed } \\
\end{array}$ \\
\hline & $\begin{array}{c}\text { Naibor Soit } \\
\text { Kubwa } \\
\text { K16A }\end{array}$ & $\begin{array}{l}\text { Qt } \\
\mathrm{z}\end{array}$ & $\begin{array}{l}\mathrm{W} \\
1\end{array}$ & $\mathrm{~N}$ & $\mathrm{~N}$ & $\begin{array}{c}35.3 \\
5213 \\
6\end{array}$ & $\begin{array}{c}- \\
2.97 \\
0256\end{array}$ & $\begin{array}{l}1517 \\
.62\end{array}$ & $\begin{array}{c}293 . \\
55\end{array}$ & $94 * 70 * 40$ & $\begin{array}{c}\text { N8-5Y } \\
8 / 1\end{array}$ & $\begin{array}{l}\text { Homogen } \\
\text { eous }\end{array}$ & N-P & & $\begin{array}{c}\text { Primar } \\
\mathrm{y}\end{array}$ & $\begin{array}{l}\text { Fully } \\
\text { Cortical }\end{array}$ & $\begin{array}{c}\text { Dull- } \\
\text { Milk } \\
\mathrm{y}\end{array}$ & Opaque & Coarse & $\begin{array}{c}\text { Foliat } \\
\text { ed }\end{array}$ \\
\hline & $\begin{array}{c}\text { Naibor Soit } \\
\text { Kubwa } \\
\text { K16B }\end{array}$ & $\begin{array}{l}\text { Qt } \\
\mathrm{z}\end{array}$ & R3 & $\mathrm{N}$ & $\mathrm{N}$ & $\begin{array}{c}35.3 \\
5199 \\
4\end{array}$ & $\begin{array}{c}- \\
2.97 \\
0327\end{array}$ & $\begin{array}{l}1516 \\
.98\end{array}$ & $\begin{array}{c}332 . \\
61\end{array}$ & $\begin{array}{c}106 * 61 * 4 \\
2\end{array}$ & $\begin{array}{c}5 \mathrm{YR} \\
6 / 4-5 \mathrm{R} \\
4 / 2\end{array}$ & $\begin{array}{l}\text { Homogen } \\
\text { eous }\end{array}$ & N-P & & $\begin{array}{c}\text { Primar } \\
\text { y }\end{array}$ & $\begin{array}{l}\text { Fully } \\
\text { Cortical }\end{array}$ & $\begin{array}{c}\text { Milk } \\
\text { y }\end{array}$ & Opaque & Very Coarse & $\begin{array}{l}\text { Non- } \\
\text { Foliat } \\
\text { ed }\end{array}$ \\
\hline & $\begin{array}{c}\text { Naibor Soit } \\
\text { Kubwa } \\
\text { K16C }\end{array}$ & $\begin{array}{l}\text { Qt } \\
\mathrm{z}\end{array}$ & $\mathrm{R} 1$ & $\mathrm{~N}$ & $\mathrm{~N}$ & $\begin{array}{c}35.3 \\
5206 \\
7 \\
\end{array}$ & $\begin{array}{l}- \\
2.97 \\
031 \\
\end{array}$ & $\begin{array}{l}1516 \\
.66\end{array}$ & $\begin{array}{c}205 . \\
66\end{array}$ & $\begin{array}{c}101 * 55 * 2 \\
8\end{array}$ & $\begin{array}{c}5 \mathrm{YR} \\
6 / 4-5 \mathrm{YR} \\
5 / 6 \\
\end{array}$ & $\begin{array}{l}\text { Homogen } \\
\text { eous }\end{array}$ & N-P & & $\begin{array}{c}\text { Primar } \\
\mathrm{y}\end{array}$ & $\begin{array}{c}\text { Cortex } \\
\text { Dominant }\end{array}$ & Dull & Opaque & Coarse & $\begin{array}{l}\text { Non- } \\
\text { Foliat } \\
\text { ed }\end{array}$ \\
\hline & $\begin{array}{c}\text { Naibor Soit } \\
\text { Kubwa } 1\end{array}$ & $\begin{array}{l}\text { Qt } \\
\mathrm{z}\end{array}$ & R3 & $\mathrm{Y}$ & $\mathrm{Y}$ & $\begin{array}{c}35.3 \\
5266 \\
2 \\
\end{array}$ & $\begin{array}{c}- \\
2.97 \\
0767\end{array}$ & $\begin{array}{c}1500 \\
.893 \\
4 \\
\end{array}$ & $\begin{array}{c}293 . \\
17\end{array}$ & $\begin{array}{c}100 * 60 * 4 \\
1\end{array}$ & 5 YR $8 / 4$ & $\begin{array}{l}\text { Homogen } \\
\text { ous }\end{array}$ & N-P & & $\begin{array}{c}\text { Primar } \\
\text { y }\end{array}$ & $\begin{array}{c}\text { Cortex } \\
\text { Dominant }\end{array}$ & Dull & Opaque & Coarse & $\begin{array}{l}\text { Non- } \\
\text { Foliat } \\
\text { ed }\end{array}$ \\
\hline & $\begin{array}{l}\text { Naibor Soit } \\
\text { Kubwa } 10\end{array}$ & $\begin{array}{l}\text { Qt } \\
\mathrm{z}\end{array}$ & $\begin{array}{l}\text { W } \\
3\end{array}$ & $\mathrm{~N}$ & $\mathrm{~N}$ & $\begin{array}{l}35.3 \\
5291\end{array}$ & $\begin{array}{c}- \\
2.97 \\
0448\end{array}$ & $\begin{array}{c}1511 \\
.521 \\
4\end{array}$ & $\begin{array}{c}172 . \\
86\end{array}$ & $80 * 45 * 38$ & N9 & $\begin{array}{l}\text { Homogen } \\
\text { ous }\end{array}$ & N-P & & $\begin{array}{c}\text { Primar } \\
\text { y }\end{array}$ & $\begin{array}{c}\text { Cortex } \\
\text { Dominant }\end{array}$ & Dull & $\begin{array}{c}\text { Edge- } \\
\text { Transpar } \\
\text { ent }\end{array}$ & Coarse & $\begin{array}{l}\text { Non- } \\
\text { Foliat } \\
\text { ed }\end{array}$ \\
\hline
\end{tabular}




\begin{tabular}{|c|c|c|c|c|c|c|c|c|c|c|c|c|c|c|c|c|c|c|c|c|}
\hline Outcrop & Sample ID & $\begin{array}{l}\mathbf{R} \\
\mathbf{o c} \\
\mathbf{k} \\
\end{array}$ & $\begin{array}{l}\mathbf{R} \\
\mathbf{M} \\
\mathbf{G} \\
\end{array}$ & $\begin{array}{c}\text { ED } \\
\text { XR } \\
\text { F } \\
\end{array}$ & $\begin{array}{c}\begin{array}{c}\text { Petro } \\
\text { graph } \\
\mathbf{y}\end{array} \\
\end{array}$ & $\begin{array}{l}\text { Lon } \\
\text { g. }\end{array}$ & Lat. & Alt. & $\begin{array}{l}\text { Mas } \\
\text { s (g) }\end{array}$ & $\begin{array}{c}\text { Size } \\
\text { (mm; } \\
\text { LxWxT) }\end{array}$ & $\begin{array}{c}\text { Munsell } \\
\text { Code }\end{array}$ & $\begin{array}{c}\text { Striping } \\
\text { Zonation }\end{array}$ & Patina & Patina Color & $\begin{array}{c}\text { Corte } \\
\text { x } \\
\text { Type } \\
\end{array}$ & $\begin{array}{c}\text { Cortex } \\
\text { Proportio } \\
\text { n }\end{array}$ & Gloss & $\begin{array}{c}\text { Transpa } \\
\text { rency }\end{array}$ & Grain Size & $\begin{array}{c}\text { Foliat } \\
\text { ion }\end{array}$ \\
\hline & $\begin{array}{c}\text { Naibor Soit } \\
\text { Kubwa } 11\end{array}$ & $\begin{array}{l}\text { Qt } \\
\mathrm{z}\end{array}$ & $\begin{array}{l}\mathrm{W} \\
3\end{array}$ & $\mathrm{Y}$ & $\mathrm{N}$ & $\begin{array}{l}35.3 \\
529\end{array}$ & $\begin{array}{c}- \\
2.97 \\
0252 \\
\end{array}$ & $\begin{array}{c}1518 \\
.263 \\
4 \\
\end{array}$ & $\begin{array}{c}157 . \\
11\end{array}$ & $\begin{array}{c}110 * 48 * 2 \\
5\end{array}$ & N9 & $\begin{array}{l}\text { Homogen } \\
\text { ous }\end{array}$ & N-P & & $\begin{array}{c}\text { Primar } \\
y\end{array}$ & $\begin{array}{c}\text { Cortex } \\
\text { Non- } \\
\text { Dominant } \\
\end{array}$ & $\begin{array}{c}\text { Dull- } \\
\text { Milk } \\
\mathrm{y}\end{array}$ & $\begin{array}{c}\text { Edge- } \\
\text { Transpar } \\
\text { ent }\end{array}$ & Coarse & $\begin{array}{c}\text { Non- } \\
\text { Foliat } \\
\text { ed }\end{array}$ \\
\hline & $\begin{array}{l}\text { Naibor Soit } \\
\text { Kubwa } 12\end{array}$ & $\begin{array}{l}\text { Qt } \\
\mathrm{z}\end{array}$ & R3 & $\mathrm{N}$ & $\mathrm{N}$ & $\begin{array}{l}35.3 \\
5275\end{array}$ & $\begin{array}{c}- \\
2.96 \\
9684 \\
\end{array}$ & $\begin{array}{l}1533 \\
.119\end{array}$ & $\begin{array}{c}332 . \\
98\end{array}$ & $73 * 72 * 70$ & $5 \mathrm{YR} 8 / 4$ & $\begin{array}{c}\text { Homogen } \\
\text { ous }\end{array}$ & N-P & & $\begin{array}{c}\text { Primar } \\
\text { y }\end{array}$ & $\begin{array}{c}\text { Cortex } \\
\text { Dominant }\end{array}$ & Dull & Opaque & Coarse & $\begin{array}{c}\text { Non- } \\
\text { Foliat } \\
\text { ed }\end{array}$ \\
\hline & $\begin{array}{c}\text { Naibor Soit } \\
\text { Kubwa } 13\end{array}$ & $\begin{array}{l}\text { Qt } \\
\mathrm{z}\end{array}$ & R3 & $\mathrm{Y}$ & $\mathrm{Y}$ & $\begin{array}{c}35.3 \\
5253 \\
5 \\
\end{array}$ & $\begin{array}{l}2.96 \\
955 \\
\end{array}$ & $\begin{array}{c}1543 \\
.760 \\
9 \\
\end{array}$ & $\begin{array}{c}234 . \\
13\end{array}$ & $92 * 70 * 30$ & $5 Y R 8 / 1$ & $\begin{array}{c}\text { Homogen } \\
\text { ous }\end{array}$ & N-P & & $\begin{array}{c}\text { Primar } \\
\text { y }\end{array}$ & $\begin{array}{c}\text { Cortex } \\
\text { Non- } \\
\text { Dominant } \\
\end{array}$ & Dull & $\begin{array}{c}\text { Edge- } \\
\text { Transpar } \\
\text { ent }\end{array}$ & Coarse & $\begin{array}{l}\text { Non- } \\
\text { Foliat } \\
\text { ed }\end{array}$ \\
\hline & $\begin{array}{c}\text { Naibor Soit } \\
\text { Kubwa } 14\end{array}$ & $\begin{array}{l}\text { Qt } \\
\mathrm{z}\end{array}$ & $\begin{array}{l}\mathrm{W} \\
2\end{array}$ & $\mathrm{Y}$ & $\mathrm{N}$ & $\begin{array}{c}35.3 \\
5240 \\
3\end{array}$ & $\begin{array}{l}2.96 \\
9346\end{array}$ & $\begin{array}{c}1546 \\
.023 \\
3\end{array}$ & nd & $86 * 53 * 40$ & $5 \mathrm{YR} 8 / 1$ & $\begin{array}{l}\text { Homogen } \\
\text { ous }\end{array}$ & N-P & & $\begin{array}{c}\text { Primar } \\
\text { y }\end{array}$ & $\begin{array}{c}\text { Cortex } \\
\text { Non- } \\
\text { Dominant }\end{array}$ & Dull & $\begin{array}{c}\text { Edge- } \\
\text { Transpar } \\
\text { ent }\end{array}$ & Coarse & $\begin{array}{l}\text { Non- } \\
\text { Foliat } \\
\text { ed }\end{array}$ \\
\hline & $\begin{array}{l}\text { Naibor Soit } \\
\text { Kubwa } 15\end{array}$ & $\begin{array}{l}\text { Qt } \\
\mathrm{z}\end{array}$ & R3 & $\mathrm{N}$ & $\mathrm{N}$ & $\begin{array}{c}35.3 \\
5241 \\
9 \\
\end{array}$ & $\begin{array}{c}- \\
2.96 \\
8874 \\
\end{array}$ & $\begin{array}{c}1545 \\
.297 \\
5 \\
\end{array}$ & $\begin{array}{c}131 . \\
19\end{array}$ & $68 * 51 * 28$ & $5 Y R 8 / 4$ & $\begin{array}{c}\text { Homogen } \\
\text { ous }\end{array}$ & N-P & & $\begin{array}{c}\text { Primar } \\
\text { y }\end{array}$ & $\begin{array}{c}\text { Cortex } \\
\text { Non- } \\
\text { Dominant }\end{array}$ & Dull & $\begin{array}{c}\text { Edge- } \\
\text { Transpar } \\
\text { ent }\end{array}$ & Coarse & $\begin{array}{l}\text { Non- } \\
\text { Foliat } \\
\text { ed }\end{array}$ \\
\hline & $\begin{array}{c}\text { Naibor Soit } \\
\text { Kubwa } 16\end{array}$ & $\begin{array}{l}\text { Qt } \\
\mathrm{z}\end{array}$ & $\begin{array}{l}\text { W } \\
3\end{array}$ & $\mathrm{~N}$ & $\mathrm{~N}$ & $\begin{array}{c}35.3 \\
5248 \\
5 \\
\end{array}$ & $\begin{array}{r}- \\
2.96 \\
8661 \\
\end{array}$ & $\begin{array}{c}1548 \\
.363 \\
9 \\
\end{array}$ & $\begin{array}{c}106 . \\
11\end{array}$ & $\begin{array}{c}113 * 45 * 2 \\
1\end{array}$ & N9 & $\begin{array}{c}\text { Homogen } \\
\text { ous }\end{array}$ & N-P & & $\begin{array}{c}\text { Primar } \\
\text { y }\end{array}$ & $\begin{array}{c}\text { Cortex } \\
\text { Non- } \\
\text { Dominant } \\
\end{array}$ & Dull & $\begin{array}{c}\text { Transpar } \\
\text { ent }\end{array}$ & Coarse & $\begin{array}{c}\begin{array}{c}\text { Non- } \\
\text { Foliat } \\
\text { ed }\end{array} \\
\end{array}$ \\
\hline & $\begin{array}{c}\text { Naibor Soit } \\
\text { Kubwa } 18\end{array}$ & $\begin{array}{l}\text { Qt } \\
\mathrm{z}\end{array}$ & $\begin{array}{l}\mathrm{w} \\
3\end{array}$ & $\mathrm{~N}$ & $\mathrm{~N}$ & $\begin{array}{c}35.3 \\
5189 \\
9\end{array}$ & $\begin{array}{c}- \\
2.96 \\
7022\end{array}$ & $\begin{array}{c}1565 \\
.473 \\
6\end{array}$ & $\begin{array}{c}167 . \\
51\end{array}$ & $67 * 67 * 45$ & N8 & $\begin{array}{l}\text { Homogen } \\
\text { ous }\end{array}$ & N-P & & $\begin{array}{c}\text { Primar } \\
\mathrm{y}\end{array}$ & $\begin{array}{c}\text { Cortex } \\
\text { Non- } \\
\text { Dominant }\end{array}$ & Dull & $\begin{array}{c}\text { Edge- } \\
\text { Transpar } \\
\text { ent }\end{array}$ & Coarse & $\begin{array}{l}\text { Non- } \\
\text { Foliat } \\
\text { ed }\end{array}$ \\
\hline & $\begin{array}{c}\text { Naibor Soit } \\
\text { Kubwa } 19\end{array}$ & $\begin{array}{l}\text { Qt } \\
\mathrm{z}\end{array}$ & R3 & $\mathrm{N}$ & $\mathrm{N}$ & $\begin{array}{c}35.3 \\
5211 \\
8 \\
\end{array}$ & $\begin{array}{c}- \\
2.96 \\
6782 \\
\end{array}$ & $\begin{array}{c}1549 \\
.969 \\
5 \\
\end{array}$ & $\begin{array}{c}87.1 \\
6\end{array}$ & $74 * 50 * 25$ & 10R $7 / 4$ & $\begin{array}{c}\text { Homogen } \\
\text { ous }\end{array}$ & N-P & & $\begin{array}{c}\text { Primar } \\
\text { y }\end{array}$ & $\begin{array}{c}\text { Cortex } \\
\text { Non- } \\
\text { Dominant }\end{array}$ & Dull & $\begin{array}{c}\text { Edge- } \\
\text { Transpar } \\
\text { ent }\end{array}$ & Coarse & $\begin{array}{l}\text { Non- } \\
\text { Foliat } \\
\text { ed }\end{array}$ \\
\hline & $\begin{array}{c}\text { Naibor Soit } \\
\text { Kubwa } 2\end{array}$ & $\begin{array}{l}\mathrm{Qt} \\
\mathrm{z}\end{array}$ & $\begin{array}{l}\mathrm{W} \\
3\end{array}$ & $\mathrm{Y}$ & $\mathrm{Y}$ & $\begin{array}{c}35.3 \\
5244 \\
6 \\
\end{array}$ & $\begin{array}{c}- \\
2.97 \\
0747 \\
\end{array}$ & $\begin{array}{c}1499 \\
.945 \\
9 \\
\end{array}$ & $\begin{array}{c}255 . \\
12\end{array}$ & $78 * 68 * 49$ & $10 \mathrm{R} 8 / 2$ & $\begin{array}{l}\text { Homogen } \\
\text { ous }\end{array}$ & N-P & & $\begin{array}{c}\text { Primar } \\
y\end{array}$ & $\begin{array}{c}\text { Cortex } \\
\text { Non- } \\
\text { Dominant } \\
\end{array}$ & Dull & Opaque & Coarse & $\begin{array}{c}\text { Non- } \\
\text { Foliat } \\
\text { ed }\end{array}$ \\
\hline & $\begin{array}{c}\text { Naibor Soit } \\
\text { Kubwa } 20\end{array}$ & $\begin{array}{l}\text { Qt } \\
\mathrm{z}\end{array}$ & $\begin{array}{l}\mathrm{W} \\
3\end{array}$ & $\mathrm{~N}$ & $\mathrm{~N}$ & $\begin{array}{c}35.3 \\
5253 \\
7\end{array}$ & $\begin{array}{l}- \\
2.96 \\
687\end{array}$ & $\begin{array}{c}1543 \\
.988 \\
5\end{array}$ & $\begin{array}{c}72.7 \\
7\end{array}$ & $53 * 40 * 25$ & N8 & $\begin{array}{c}\text { Homogen } \\
\text { ous }\end{array}$ & N-P & & $\begin{array}{l}\text { Secon } \\
\text { dary }\end{array}$ & $\begin{array}{c}\text { Cortex } \\
\text { Non- } \\
\text { Dominant }\end{array}$ & Dull & $\begin{array}{c}\text { Edge- } \\
\text { Transpar } \\
\text { ent }\end{array}$ & Coarse & $\begin{array}{l}\text { Non- } \\
\text { Foliat } \\
\text { ed }\end{array}$ \\
\hline & $\begin{array}{c}\text { Naibor Soit } \\
\text { Kubwa } 21\end{array}$ & $\begin{array}{l}\text { Qt } \\
\mathrm{z}\end{array}$ & R3 & $\mathrm{N}$ & $\mathrm{N}$ & $\begin{array}{c}35.3 \\
5271 \\
9\end{array}$ & $\begin{array}{l}- \\
2.96 \\
6844\end{array}$ & $\begin{array}{c}1536 \\
.490 \\
8\end{array}$ & $\begin{array}{c}73.8 \\
7\end{array}$ & $66 * 43 * 30$ & $\begin{array}{c}5 \mathrm{YR} \\
7 / 2-5 \mathrm{YR} \\
8 / 4\end{array}$ & Zoned & N-P & & $\begin{array}{c}\text { Primar } \\
\text { y }\end{array}$ & $\begin{array}{c}\text { Cortex } \\
\text { Non- } \\
\text { Dominant }\end{array}$ & Dull & $\begin{array}{c}\text { Edge- } \\
\text { Transpar } \\
\text { ent }\end{array}$ & Coarse & $\begin{array}{l}\text { Non- } \\
\text { Foliat } \\
\text { ed }\end{array}$ \\
\hline & $\begin{array}{l}\text { Naibor Soit } \\
\text { Kubwa } 22\end{array}$ & $\begin{array}{l}\text { Qt } \\
\mathrm{z}\end{array}$ & $\begin{array}{l}\text { w } \\
3\end{array}$ & $\mathrm{~N}$ & $\mathrm{~N}$ & $\begin{array}{c}35.3 \\
5307 \\
5 \\
\end{array}$ & $\begin{array}{c}- \\
2.96 \\
7735 \\
\end{array}$ & $\begin{array}{c}1539 \\
.775 \\
1 \\
\end{array}$ & $\begin{array}{c}146 . \\
50\end{array}$ & $60 * 40 * 40$ & N8 & $\begin{array}{l}\text { Homogen } \\
\text { ous }\end{array}$ & N-P & & $\begin{array}{c}\text { Primar } \\
y\end{array}$ & $\begin{array}{c}\text { Cortex } \\
\text { Non- } \\
\text { Dominant } \\
\end{array}$ & Dull & $\begin{array}{c}\text { Edge- } \\
\text { Transpar } \\
\text { ent } \\
\end{array}$ & Coarse & $\begin{array}{c}\begin{array}{c}\text { Non- } \\
\text { Foliat } \\
\text { ed }\end{array} \\
\end{array}$ \\
\hline & $\begin{array}{c}\text { Naibor Soit } \\
\text { Kubwa } 23\end{array}$ & $\begin{array}{l}\text { Qt } \\
\mathrm{z}\end{array}$ & R3 & $\mathrm{N}$ & $\mathrm{N}$ & $\begin{array}{c}35.3 \\
5131 \\
2\end{array}$ & $\begin{array}{c}- \\
2.96 \\
7576\end{array}$ & $\begin{array}{c}1534 \\
.378 \\
9\end{array}$ & $\begin{array}{c}361 . \\
75\end{array}$ & $70 * 67 * 47$ & $5 \mathrm{YR} 8 / 4$ & $\begin{array}{c}\text { Homogen } \\
\text { ous }\end{array}$ & N-P & & $\begin{array}{c}\text { Primar } \\
\text { y }\end{array}$ & $\begin{array}{c}\text { Cortex } \\
\text { Dominant }\end{array}$ & Dull & Opaque & Coarse & $\begin{array}{l}\text { Non- } \\
\text { Foliat } \\
\text { ed }\end{array}$ \\
\hline & $\begin{array}{c}\text { Naibor Soit } \\
\text { Kubwa } 24\end{array}$ & $\begin{array}{l}\text { Qt } \\
\mathrm{z}\end{array}$ & $\begin{array}{l}\text { W } \\
2\end{array}$ & $\mathrm{Y}$ & $\mathrm{N}$ & $\begin{array}{c}35.3 \\
5132 \\
5\end{array}$ & $\begin{array}{l}- \\
2.96 \\
6961\end{array}$ & $\begin{array}{c}1546 \\
.618 \\
7\end{array}$ & $\begin{array}{c}240 . \\
18\end{array}$ & $75 * 72 * 60$ & $\begin{array}{c}\mathrm{N} 9-5 \mathrm{YR} \\
8 / 4\end{array}$ & Zoned & N-P & & $\begin{array}{c}\text { Primar } \\
y\end{array}$ & $\begin{array}{c}\text { Cortex } \\
\text { Non- } \\
\text { Dominant }\end{array}$ & Dull & Opaque & Coarse & $\begin{array}{l}\text { Non- } \\
\text { Foliat } \\
\text { ed }\end{array}$ \\
\hline & $\begin{array}{l}\text { Naibor Soit } \\
\text { Kubwa } 25\end{array}$ & $\begin{array}{l}\text { Qt } \\
\mathrm{z}\end{array}$ & $\begin{array}{l}\text { W } \\
3\end{array}$ & $\mathrm{~N}$ & $\mathrm{~N}$ & $\begin{array}{c}35.3 \\
5091 \\
7\end{array}$ & $\begin{array}{r}- \\
2.96 \\
6682\end{array}$ & $\begin{array}{c}1541 \\
.757 \\
6\end{array}$ & $\begin{array}{l}71.6 \\
8\end{array}$ & $64 * 50 * 15$ & N8 & $\begin{array}{c}\text { Homogen } \\
\text { ous }\end{array}$ & N-P & & $\begin{array}{c}\text { Primar } \\
\text { y }\end{array}$ & $\begin{array}{c}\text { Cortex } \\
\text { Non- } \\
\text { Dominant }\end{array}$ & Dull & $\begin{array}{c}\text { Transpar } \\
\text { ent }\end{array}$ & Coarse & $\begin{array}{l}\text { Non- } \\
\text { Foliat } \\
\text { ed }\end{array}$ \\
\hline & $\begin{array}{l}\text { Naibor Soit } \\
\text { Kubwa } 26\end{array}$ & $\begin{array}{l}\text { Qt } \\
\mathrm{z}\end{array}$ & R3 & $\mathrm{N}$ & $\mathrm{N}$ & $\begin{array}{c}35.3 \\
4920 \\
3 \\
\end{array}$ & $\begin{array}{r}- \\
2.96 \\
6415 \\
\end{array}$ & $\begin{array}{c}1546 \\
.509 \\
8 \\
\end{array}$ & $\begin{array}{c}325 . \\
33\end{array}$ & $\begin{array}{c}105 * 65 * 5 \\
3\end{array}$ & $5 Y R \quad 8 / 4$ & $\begin{array}{l}\text { Homogen } \\
\text { ous }\end{array}$ & N-P & & $\begin{array}{c}\text { Primar } \\
y\end{array}$ & $\begin{array}{c}\text { Cortex } \\
\text { Dominant }\end{array}$ & Dull & $\begin{array}{c}\text { Edge- } \\
\text { Transpar } \\
\text { ent }\end{array}$ & Coarse & $\begin{array}{l}\text { Non- } \\
\text { Foliat } \\
\text { ed }\end{array}$ \\
\hline & $\begin{array}{l}\text { Naibor Soit } \\
\text { Kubwa } 27\end{array}$ & $\begin{array}{l}\text { Qt } \\
\mathrm{z}\end{array}$ & R3 & $\mathrm{Y}$ & $\mathrm{N}$ & $\begin{array}{c}35.3 \\
4741 \\
1\end{array}$ & $\begin{array}{l}- \\
2.96 \\
4801\end{array}$ & $\begin{array}{c}1544 \\
.821 \\
3\end{array}$ & $\begin{array}{c}353 . \\
85\end{array}$ & $\begin{array}{c}100 * 70 * 4 \\
0\end{array}$ & $5 Y R 7 / 2$ & $\begin{array}{c}\text { Homogen } \\
\text { ous }\end{array}$ & N-P & & $\begin{array}{c}\text { Primar } \\
\mathrm{y}\end{array}$ & $\begin{array}{c}\text { Cortex } \\
\text { Dominant }\end{array}$ & Dull & Opaque & Coarse & $\begin{array}{c}\text { Foliat } \\
\text { ed }\end{array}$ \\
\hline & $\begin{array}{c}\text { Naibor Soit } \\
\text { Kubwa } 3\end{array}$ & $\begin{array}{l}\text { Qt } \\
\mathrm{z}\end{array}$ & $\begin{array}{l}\text { W } \\
3\end{array}$ & $\mathrm{~N}$ & $\mathrm{~N}$ & $\begin{array}{c}1 \\
35.3 \\
5214 \\
1\end{array}$ & $\begin{array}{l}- \\
2.97 \\
0678\end{array}$ & $\begin{array}{c}1498 \\
.029 \\
8\end{array}$ & $\begin{array}{c}84.3 \\
6\end{array}$ & $72 * 50 * 37$ & $5 \mathrm{YR} 8 / 1$ & $\begin{array}{l}\text { Homogen } \\
\text { ous }\end{array}$ & N-P & & $\begin{array}{l}\text { Secon } \\
\text { dary }\end{array}$ & $\begin{array}{c}\text { Cortex } \\
\text { Non- } \\
\text { Dominant }\end{array}$ & Dull & $\begin{array}{c}\text { Edge- } \\
\text { Transpar } \\
\text { ent }\end{array}$ & Coarse & $\begin{array}{l}\text { Non- } \\
\text { Foliat } \\
\text { ed }\end{array}$ \\
\hline & $\begin{array}{c}\text { Naibor Soit } \\
\text { Kubwa } 30\end{array}$ & $\begin{array}{l}\text { Qt } \\
\mathrm{z}\end{array}$ & G1 & $\mathrm{N}$ & $\mathrm{N}$ & $\begin{array}{c}35.3 \\
4765 \\
5\end{array}$ & $\begin{array}{c}- \\
2.96 \\
0745\end{array}$ & $\begin{array}{c}1586 \\
.880 \\
7\end{array}$ & $\begin{array}{c}350 . \\
64\end{array}$ & $77 * 67 * 45$ & $5 \mathrm{G} 8 / 1$ & $\begin{array}{l}\text { Homogen } \\
\text { ous }\end{array}$ & N-P & & $\begin{array}{c}\text { Primar } \\
\text { y }\end{array}$ & $\begin{array}{c}\text { Cortex } \\
\text { Non- } \\
\text { Dominant }\end{array}$ & Dull & $\begin{array}{c}\text { Edge- } \\
\text { Transpar } \\
\text { ent }\end{array}$ & Coarse & $\begin{array}{c}\text { Non- } \\
\text { Foliat } \\
\text { ed }\end{array}$ \\
\hline
\end{tabular}




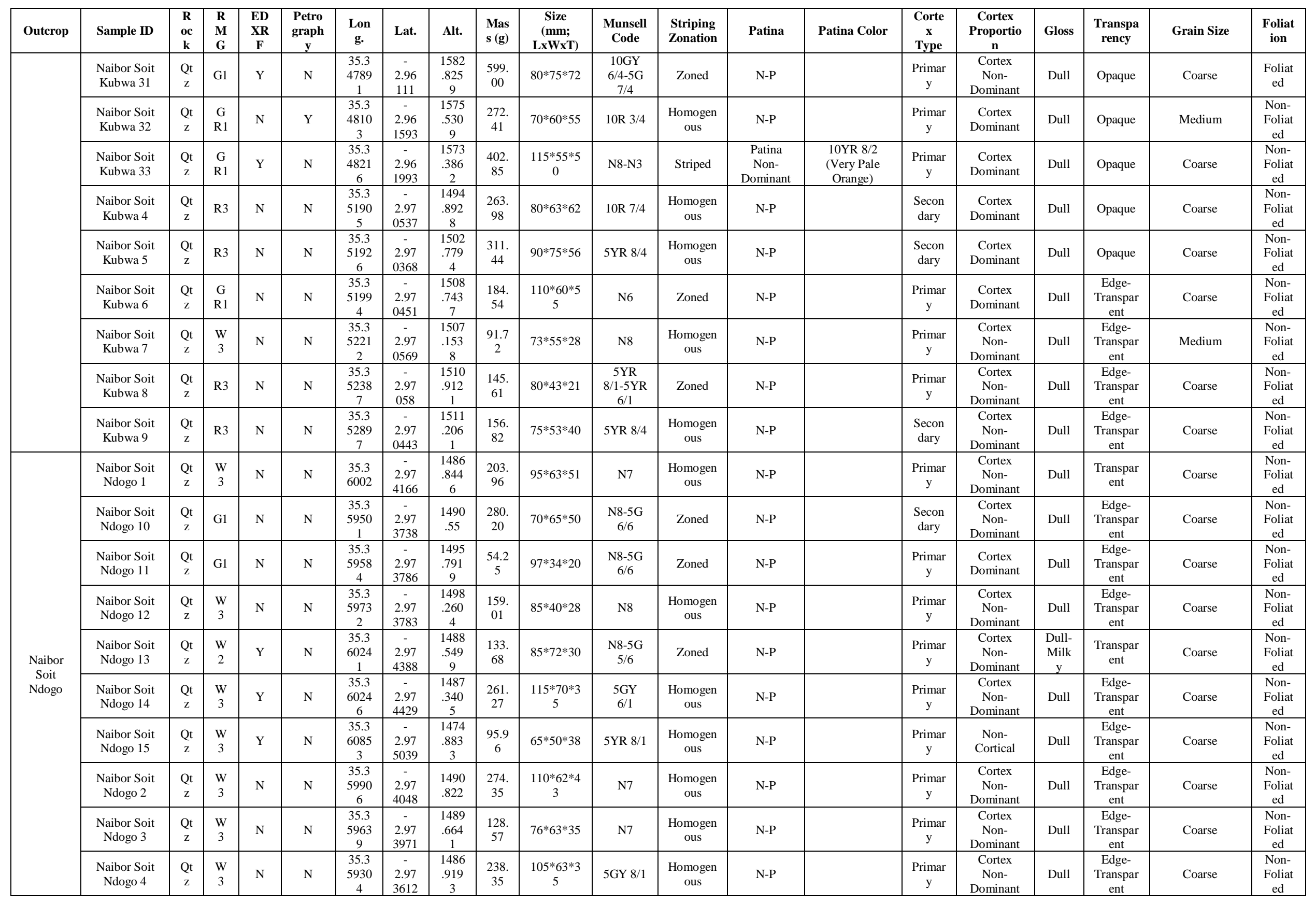




\begin{tabular}{|c|c|c|c|c|c|c|c|c|c|c|c|c|c|c|c|c|c|c|c|c|}
\hline Outcrop & Sample ID & $\begin{array}{l}\mathbf{R} \\
\mathbf{o c} \\
\mathbf{k} \\
\end{array}$ & $\begin{array}{l}\mathbf{R} \\
\mathbf{M} \\
\mathbf{G} \\
\end{array}$ & $\begin{array}{c}\text { ED } \\
\text { XR } \\
\text { F } \\
\end{array}$ & $\begin{array}{c}\text { Petro } \\
\text { graph } \\
\mathbf{y}\end{array}$ & $\begin{array}{c}\text { Lon } \\
\text { g. }\end{array}$ & Lat. & Alt. & $\begin{array}{l}\text { Mas } \\
\text { s (g) }\end{array}$ & $\begin{array}{c}\text { Size } \\
\text { (mm; } \\
\text { LxWxT) }\end{array}$ & $\begin{array}{c}\text { Munsell } \\
\text { Code }\end{array}$ & $\begin{array}{l}\text { Striping } \\
\text { Zonation }\end{array}$ & Patina & Patina Color & $\begin{array}{c}\text { Corte } \\
x \\
\text { Type } \\
\end{array}$ & $\begin{array}{c}\text { Cortex } \\
\text { Proportio } \\
\text { n } \\
\end{array}$ & Gloss & $\begin{array}{c}\text { Transpa } \\
\text { rency }\end{array}$ & Grain Size & $\begin{array}{c}\text { Foliat } \\
\text { ion }\end{array}$ \\
\hline & $\begin{array}{l}\text { Naibor Soit } \\
\text { Ndogo } 5\end{array}$ & $\begin{array}{l}\mathrm{Qt} \\
\mathrm{z}\end{array}$ & $\begin{array}{l}\mathrm{W} \\
3\end{array}$ & $\mathrm{~N}$ & $\mathrm{~N}$ & $\begin{array}{c}35.3 \\
5956 \\
8\end{array}$ & $\begin{array}{c}- \\
2.97 \\
3586\end{array}$ & $\begin{array}{c}1487 \\
.461 \\
9\end{array}$ & $\begin{array}{c}311 . \\
07\end{array}$ & $\begin{array}{c}100 * 80 * 2 \\
8\end{array}$ & N7 & $\begin{array}{c}\text { Homogen } \\
\text { ous }\end{array}$ & N-P & & $\begin{array}{c}\text { Primar } \\
\mathrm{y}\end{array}$ & $\begin{array}{c}\text { Cortex } \\
\text { Non- } \\
\text { Dominant }\end{array}$ & Dull & $\begin{array}{c}\text { Edge- } \\
\text { Transpar } \\
\text { ent }\end{array}$ & Coarse & $\begin{array}{l}\text { Non- } \\
\text { Foliat } \\
\text { ed }\end{array}$ \\
\hline & $\begin{array}{l}\text { Naibor Soit } \\
\text { Ndogo } 6\end{array}$ & $\begin{array}{l}\text { Qt } \\
\mathrm{z}\end{array}$ & $\begin{array}{l}\mathrm{W} \\
3\end{array}$ & $\mathrm{Y}$ & $\mathrm{N}$ & $\begin{array}{c}35.3 \\
5990 \\
5 \\
\end{array}$ & $\begin{array}{r}- \\
2.97 \\
3845 \\
\end{array}$ & $\begin{array}{c}1490 \\
.372 \\
3 \\
\end{array}$ & $\begin{array}{c}162 . \\
00\end{array}$ & $75 * 65 * 33$ & $5 Y 8 / 1$ & $\begin{array}{c}\text { Homogen } \\
\text { ous }\end{array}$ & N-P & & $\begin{array}{c}\text { Primar } \\
\text { y }\end{array}$ & $\begin{array}{c}\text { Cortex } \\
\text { Non- } \\
\text { Dominant } \\
\end{array}$ & Dull & $\begin{array}{c}\text { Edge- } \\
\text { Transpar } \\
\text { ent } \\
\end{array}$ & Coarse & $\begin{array}{c}\begin{array}{c}\text { Non- } \\
\text { Foliat } \\
\text { ed }\end{array} \\
\end{array}$ \\
\hline & $\begin{array}{l}\text { Naibor Soit } \\
\text { Ndogo } 7\end{array}$ & $\begin{array}{l}\text { Qt } \\
\mathrm{z}\end{array}$ & $\begin{array}{l}\text { W } \\
3\end{array}$ & $\mathrm{~N}$ & $\mathrm{~N}$ & $\begin{array}{c}35.3 \\
6010 \\
7 \\
\end{array}$ & $\begin{array}{r}2.97 \\
4133 \\
\end{array}$ & $\begin{array}{c}1489 \\
.744 \\
9 \\
\end{array}$ & $\begin{array}{c}285 . \\
80\end{array}$ & $85 * 75 * 55$ & N8 & $\begin{array}{c}\text { Homogen } \\
\text { ous }\end{array}$ & N-P & & $\begin{array}{c}\text { Primar } \\
\mathrm{y}\end{array}$ & $\begin{array}{c}\text { Cortex } \\
\text { Non- } \\
\text { Dominant } \\
\end{array}$ & Dull & $\begin{array}{c}\text { Edge- } \\
\text { Transpar } \\
\text { ent }\end{array}$ & Coarse & $\begin{array}{l}\text { Non- } \\
\text { Foliat } \\
\text { ed }\end{array}$ \\
\hline & $\begin{array}{l}\text { Naibor Soit } \\
\text { Ndogo } 8\end{array}$ & $\begin{array}{l}\text { Qt } \\
\mathrm{z}\end{array}$ & $\begin{array}{l}\text { W } \\
3\end{array}$ & $\mathrm{Y}$ & $\mathrm{N}$ & $\begin{array}{c}35.3 \\
5974 \\
6 \\
\end{array}$ & $\begin{array}{r}2.97 \\
3955 \\
\end{array}$ & $\begin{array}{l}1491 \\
.949\end{array}$ & $\begin{array}{c}130 . \\
27\end{array}$ & $94 * 65 * 35$ & N8 & $\begin{array}{c}\text { Homogen } \\
\text { ous }\end{array}$ & N-P & & $\begin{array}{c}\text { Primar } \\
y\end{array}$ & $\begin{array}{l}\text { Non- } \\
\text { Cortical }\end{array}$ & Dull & $\begin{array}{c}\text { Edge- } \\
\text { Transpar } \\
\text { ent } \\
\end{array}$ & Coarse & $\begin{array}{c}\text { Non- } \\
\text { Foliat } \\
\text { ed } \\
\end{array}$ \\
\hline & $\begin{array}{l}\text { Naibor Soit } \\
\text { Ndogo } 9\end{array}$ & $\begin{array}{l}\text { Qt } \\
\mathrm{z}\end{array}$ & $\begin{array}{l}\text { W } \\
3\end{array}$ & $\mathrm{~N}$ & $\mathrm{~N}$ & $\begin{array}{c}35.3 \\
5955 \\
2 \\
\end{array}$ & $\begin{array}{r}- \\
2.97 \\
3714 \\
\end{array}$ & $\begin{array}{c}1495 \\
.207 \\
4 \\
\end{array}$ & $\begin{array}{c}206 . \\
00\end{array}$ & $81 * 50 * 45$ & N9 & $\begin{array}{c}\text { Homogen } \\
\text { ous }\end{array}$ & N-P & & $\begin{array}{c}\text { Primar } \\
\mathrm{y}\end{array}$ & $\begin{array}{c}\text { Cortex } \\
\text { Non- } \\
\text { Dominant } \\
\end{array}$ & Dull & $\begin{array}{c}\text { Edge- } \\
\text { Transpar } \\
\text { ent } \\
\end{array}$ & Coarse & $\begin{array}{c}\begin{array}{c}\text { Non- } \\
\text { Foliat } \\
\text { ed }\end{array} \\
\end{array}$ \\
\hline & $\begin{array}{l}\text { Naibor Soit } \\
\text { Ndogo S18A }\end{array}$ & $\begin{array}{l}\text { Qt } \\
\mathrm{z}\end{array}$ & G1 & $\mathrm{N}$ & $\mathrm{N}$ & $\begin{array}{c}35.3 \\
5859 \\
7 \\
\end{array}$ & $\begin{array}{r}2.97 \\
3413 \\
\end{array}$ & $\begin{array}{c}1475 \\
.71\end{array}$ & $\begin{array}{c}308 . \\
18\end{array}$ & $77 * 70 * 35$ & $5 \mathrm{GY} 8 / 1$ & Zoned & N-P & & $\begin{array}{c}\text { Primar } \\
\mathrm{y}\end{array}$ & $\begin{array}{c}\text { Fully } \\
\text { Cortical }\end{array}$ & $\begin{array}{c}\text { Milk } \\
\text { y }\end{array}$ & Opaque & Coarse-Medium & $\begin{array}{c}\begin{array}{c}\text { Non- } \\
\text { Foliat } \\
\text { ed }\end{array} \\
\end{array}$ \\
\hline & $\begin{array}{c}\text { Naibor Soit } \\
\text { Ndogo S18B }\end{array}$ & $\begin{array}{l}\text { Qt } \\
\mathrm{z}\end{array}$ & $\begin{array}{l}\mathrm{W} \\
2\end{array}$ & $\mathrm{~N}$ & $\mathrm{~N}$ & $\begin{array}{c}35.3 \\
5858 \\
3 \\
\end{array}$ & $\begin{array}{r}2.97 \\
3375 \\
\end{array}$ & $\begin{array}{c}1476 \\
.78\end{array}$ & $\begin{array}{l}>50 \\
0.00\end{array}$ & $\begin{array}{c}120 * 69 * 4 \\
9\end{array}$ & $5 \mathrm{YR} 8 / 1$ & $\begin{array}{c}\text { Homogen } \\
\text { eous }\end{array}$ & N-P & & $\begin{array}{c}\text { Primar } \\
\mathrm{y}\end{array}$ & $\begin{array}{c}\text { Cortex } \\
\text { Dominant }\end{array}$ & $\begin{array}{c}\text { Milk } \\
\mathrm{y}\end{array}$ & Opaque & Coarse & $\begin{array}{c}\text { Non- } \\
\text { Foliat } \\
\text { ed } \\
\end{array}$ \\
\hline & $\begin{array}{c}\text { Naibor Soit } \\
\text { Ndogo S18C }\end{array}$ & $\begin{array}{l}\text { Qt } \\
\mathrm{z}\end{array}$ & $\begin{array}{l}\mathrm{W} \\
1\end{array}$ & $\mathrm{~N}$ & $\mathrm{~N}$ & $\begin{array}{c}35.3 \\
5858 \\
4 \\
\end{array}$ & $\begin{array}{c}- \\
2.97 \\
338 \\
\end{array}$ & $\begin{array}{l}1477 \\
.48\end{array}$ & $\begin{array}{c}271 . \\
39\end{array}$ & $71 * 54 * 39$ & $\begin{array}{c}\mathrm{N} 8-5 \mathrm{Y} \\
8 / 1\end{array}$ & $\begin{array}{c}\text { Homogen } \\
\text { eous }\end{array}$ & N-P & & $\begin{array}{c}\text { Primar } \\
\mathrm{y}\end{array}$ & $\begin{array}{c}\text { Cortex } \\
\text { Dominant }\end{array}$ & $\begin{array}{c}\text { Milk } \\
\text { y }\end{array}$ & Opaque & Coarse & $\begin{array}{c}\begin{array}{c}\text { Non- } \\
\text { Foliat } \\
\text { ed }\end{array} \\
\end{array}$ \\
\hline & $\begin{array}{r}\text { Naibor Soit } \\
\text { Ndogo S19A }\end{array}$ & $\begin{array}{l}\text { Qt } \\
\mathrm{z}\end{array}$ & $\begin{array}{l}\mathrm{W} \\
1\end{array}$ & $\mathrm{~N}$ & $\mathrm{~N}$ & $\begin{array}{c}35.3 \\
5905 \\
6 \\
\end{array}$ & $\begin{array}{c}- \\
2.97 \\
4098 \\
\end{array}$ & $\begin{array}{l}1471 \\
.82\end{array}$ & $\begin{array}{c}200 . \\
07\end{array}$ & $81 * 56 * 46$ & $\begin{array}{c}\text { N8-5Y } \\
8 / 1\end{array}$ & $\begin{array}{c}\text { Homogen } \\
\text { eous }\end{array}$ & N-P & & $\begin{array}{c}\text { Primar } \\
\mathrm{y}\end{array}$ & $\begin{array}{c}\text { Cortex } \\
\text { Dominant }\end{array}$ & $\begin{array}{c}\text { Milk } \\
\text { y }\end{array}$ & Opaque & Coarse & $\begin{array}{c}\text { Non- } \\
\text { Foliat } \\
\text { ed }\end{array}$ \\
\hline & $\begin{array}{c}\text { Naibor Soit } \\
\text { Ndogo S19B }\end{array}$ & $\begin{array}{l}\text { Qt } \\
\mathrm{z}\end{array}$ & $\mathrm{R} 1$ & $\mathrm{~N}$ & $\mathrm{~N}$ & $\begin{array}{c}35.3 \\
5904 \\
7 \\
\end{array}$ & $\begin{array}{r}2.97 \\
4093 \\
\end{array}$ & $\begin{array}{c}1473 \\
.01\end{array}$ & $\begin{array}{c}153 . \\
55\end{array}$ & $72 * 38 * 38$ & $\begin{array}{c}5 \mathrm{YR} \\
6 / 4-5 \mathrm{YR} \\
5 / 6 \\
\end{array}$ & $\begin{array}{l}\text { Homogen } \\
\text { eous }\end{array}$ & N-P & & $\begin{array}{c}\text { Primar } \\
\text { y }\end{array}$ & $\begin{array}{c}\text { Fully } \\
\text { Cortical }\end{array}$ & $\begin{array}{c}\text { Milk } \\
\text { y }\end{array}$ & Opaque & Coarse & $\begin{array}{c}\begin{array}{c}\text { Non- } \\
\text { Foliat } \\
\text { ed }\end{array} \\
\end{array}$ \\
\hline & $\begin{array}{c}\text { Naibor Soit } \\
\text { Ndogo S19C }\end{array}$ & $\begin{array}{l}\text { Qt } \\
\mathrm{z}\end{array}$ & G1 & $\mathrm{N}$ & $\mathrm{N}$ & $\begin{array}{c}35.3 \\
5904 \\
6 \\
\end{array}$ & $\begin{array}{c}- \\
2.97 \\
4096 \\
\end{array}$ & $\begin{array}{l}1473 \\
.57\end{array}$ & $\begin{array}{l}195 . \\
95\end{array}$ & $84 * 79 * 31$ & $5 \mathrm{GY} 8 / 1$ & Zoned & N-P & & $\begin{array}{c}\text { Primar } \\
\mathrm{y}\end{array}$ & $\begin{array}{c}\text { Cortex } \\
\text { Dominant }\end{array}$ & $\begin{array}{c}\text { Milk } \\
\mathrm{y}\end{array}$ & Opaque & Coarse & $\begin{array}{c}\begin{array}{c}\text { Non- } \\
\text { Foliat } \\
\text { ed }\end{array} \\
\end{array}$ \\
\hline & $\begin{array}{c}\text { Naibor Soit } \\
\text { Ndogo S19D }\end{array}$ & $\begin{array}{l}\text { Qt } \\
\mathrm{z}\end{array}$ & $\begin{array}{l}\mathrm{W} \\
2\end{array}$ & $\mathrm{~N}$ & $\mathrm{~N}$ & $\begin{array}{l}35.3 \\
5904 \\
\end{array}$ & $\begin{array}{c}- \\
2.97 \\
4102 \\
\end{array}$ & $\begin{array}{c}1473 \\
.49\end{array}$ & $\begin{array}{c}254 . \\
88\end{array}$ & $66 * 65 * 41$ & $5 Y R 8 / 1$ & $\begin{array}{c}\text { Homogen } \\
\text { eous }\end{array}$ & N-P & & $\begin{array}{c}\text { Primar } \\
\mathrm{y}\end{array}$ & $\begin{array}{l}\text { Fully } \\
\text { Cortical }\end{array}$ & $\begin{array}{c}\text { Dull- } \\
\text { Milk } \\
\mathrm{y}\end{array}$ & Opaque & Coarse & $\begin{array}{c}\begin{array}{c}\text { Non- } \\
\text { Foliat } \\
\text { ed }\end{array} \\
\end{array}$ \\
\hline & $\begin{array}{r}\text { Naibor Soit } \\
\text { Ndogo T19A }\end{array}$ & $\begin{array}{l}\text { Qt } \\
\mathrm{z}\end{array}$ & $\begin{array}{l}\mathrm{W} \\
1\end{array}$ & $\mathrm{~N}$ & $\mathrm{~N}$ & $\begin{array}{c}35.3 \\
5989 \\
9 \\
\end{array}$ & $\begin{array}{r}2.97 \\
4605 \\
\end{array}$ & $\begin{array}{l}1478 \\
.65\end{array}$ & $\begin{array}{c}212 . \\
37\end{array}$ & $98 * 43 * 37$ & $\begin{array}{c}\mathrm{N} 8-5 \mathrm{Y} \\
8 / 1 \\
\end{array}$ & $\begin{array}{c}\text { Homogen } \\
\text { eous }\end{array}$ & N-P & & $\begin{array}{c}\text { Primar } \\
\text { y }\end{array}$ & $\begin{array}{c}\text { Cortex } \\
\text { Dominant }\end{array}$ & $\begin{array}{c}\text { Milk } \\
\text { y }\end{array}$ & Opaque & Coarse & $\begin{array}{l}\begin{array}{c}\text { Non- } \\
\text { Foliat } \\
\text { ed }\end{array} \\
\end{array}$ \\
\hline & $\begin{array}{c}\text { Naibor Soit } \\
\text { Ndogo T19B }\end{array}$ & $\begin{array}{l}\text { Qt } \\
\mathrm{z}\end{array}$ & $\mathrm{R} 1$ & $\mathrm{~N}$ & $\mathrm{~N}$ & $\begin{array}{c}35.3 \\
5989 \\
7 \\
\end{array}$ & $\begin{array}{c}- \\
2.97 \\
4606 \\
\end{array}$ & $\begin{array}{l}1480 \\
.23\end{array}$ & $\begin{array}{l}>50 \\
0.00\end{array}$ & $85 * 82 * 64$ & $\begin{array}{c}5 \mathrm{YR} \\
6 / 4-5 \mathrm{YR} \\
5 / 6 \\
\end{array}$ & $\begin{array}{c}\text { Homogen } \\
\text { eous }\end{array}$ & N-P & & $\begin{array}{c}\text { Primar } \\
\mathrm{y}\end{array}$ & $\begin{array}{c}\text { Fully } \\
\text { Cortical }\end{array}$ & Dull & Opaque & Coarse & $\begin{array}{c}\text { Non- } \\
\text { Foliat } \\
\text { ed }\end{array}$ \\
\hline & $\begin{array}{l}\text { Naibor Soit } \\
\text { Ndogo T19C }\end{array}$ & $\begin{array}{l}\text { Qt } \\
\mathrm{z}\end{array}$ & R3 & $\mathrm{N}$ & $\mathrm{N}$ & $\begin{array}{c}35.3 \\
5989 \\
8 \\
\end{array}$ & $\begin{array}{c}- \\
2.97 \\
4604 \\
\end{array}$ & $\begin{array}{l}1479 \\
.95\end{array}$ & $\begin{array}{c}206 . \\
86\end{array}$ & $73 * 72 * 24$ & $\begin{array}{c}5 \mathrm{YR} \\
6 / 4-5 \mathrm{R} \\
4 / 2 \\
\end{array}$ & $\begin{array}{c}\text { Homogen } \\
\text { eous }\end{array}$ & N-P & & $\begin{array}{c}\text { Primar } \\
\mathrm{y}\end{array}$ & $\begin{array}{c}\text { Cortex } \\
\text { Dominant }\end{array}$ & $\begin{array}{c}\text { Milk } \\
\text { y }\end{array}$ & Opaque & Very Coarse & $\begin{array}{c}\text { Foliat } \\
\text { ed }\end{array}$ \\
\hline & $\begin{array}{c}\text { Naibor Soit } \\
\text { Ndogo T19D }\end{array}$ & $\begin{array}{l}\text { Qt } \\
\mathrm{z}\end{array}$ & G1 & $\mathrm{N}$ & $\mathrm{N}$ & $\begin{array}{c}35.3 \\
5990 \\
3 \\
\end{array}$ & $\begin{array}{c}- \\
2.97 \\
4602 \\
\end{array}$ & $\begin{array}{c}1480 \\
.06\end{array}$ & $\begin{array}{c}246 . \\
15\end{array}$ & $86 * 82 * 21$ & $5 \mathrm{GY} 8 / 1$ & $\begin{array}{c}\text { Homogen } \\
\text { eous }\end{array}$ & N-P & & $\begin{array}{c}\text { Primar } \\
\text { y }\end{array}$ & $\begin{array}{l}\text { Fully } \\
\text { Cortical }\end{array}$ & $\begin{array}{c}\text { Milk } \\
\text { y }\end{array}$ & Opaque & Coarse-Medium & $\begin{array}{l}\text { Non- } \\
\text { Foliat } \\
\text { ed }\end{array}$ \\
\hline & $\begin{array}{c}\text { Naibor Soit } \\
\text { Ndogo U18A }\end{array}$ & $\begin{array}{l}\text { Qt } \\
\mathrm{z}\end{array}$ & $\begin{array}{l}\mathrm{G} \\
\mathrm{R} 1\end{array}$ & $\mathrm{~N}$ & $\mathrm{~N}$ & $\begin{array}{c}35.3 \\
5977 \\
2 \\
\end{array}$ & $\begin{array}{l}2.97 \\
3137 \\
\end{array}$ & $\begin{array}{c}1482 \\
.04\end{array}$ & $\begin{array}{c}141 . \\
59\end{array}$ & $70 * 52 * 26$ & $\begin{array}{l}5 \mathrm{~PB} 5 / 2- \\
5 \mathrm{~PB} 7 / 2\end{array}$ & $\begin{array}{c}\text { Homogen } \\
\text { eous }\end{array}$ & N-P & & $\begin{array}{c}\text { Primar } \\
y\end{array}$ & $\begin{array}{c}\text { Fully } \\
\text { Cortical }\end{array}$ & $\begin{array}{c}\text { Milk } \\
\text { y }\end{array}$ & Opaque & Coarse-Medium & $\begin{array}{l}\text { Foliat } \\
\text { ed }\end{array}$ \\
\hline & $\begin{array}{l}\text { Naibor Soit } \\
\text { Ndogo U18B }\end{array}$ & $\begin{array}{l}\text { Qt } \\
\mathrm{z}\end{array}$ & $\begin{array}{l}\mathrm{W} \\
2\end{array}$ & $\mathrm{~N}$ & $\mathrm{~N}$ & $\begin{array}{c}35.3 \\
5977 \\
3 \\
\end{array}$ & $\begin{array}{c}- \\
2.97 \\
3146 \\
\end{array}$ & $\begin{array}{c}1483 \\
.6\end{array}$ & $\begin{array}{c}110 . \\
55\end{array}$ & $71 * 49 * 30$ & $5 Y R 8 / 1$ & $\begin{array}{c}\text { Homogen } \\
\text { eous }\end{array}$ & N-P & & $\begin{array}{c}\text { Primar } \\
\mathrm{y}\end{array}$ & $\begin{array}{l}\text { Fully } \\
\text { Cortical }\end{array}$ & $\begin{array}{c}\text { Milk } \\
\text { y }\end{array}$ & Opaque & Coarse & $\begin{array}{c}\text { Non- } \\
\text { Foliat } \\
\text { ed }\end{array}$ \\
\hline & $\begin{array}{c}\text { Naibor Soit } \\
\text { Ndogo U18C }\end{array}$ & $\begin{array}{l}\text { Qt } \\
\mathrm{z}\end{array}$ & $\begin{array}{l}\mathrm{G} \\
\mathrm{R} 1\end{array}$ & $\mathrm{~N}$ & $\mathrm{~N}$ & $\begin{array}{c}35.3 \\
5977 \\
6\end{array}$ & $\begin{array}{l}- \\
2.97 \\
3148\end{array}$ & $\begin{array}{c}1483 \\
.66\end{array}$ & $\begin{array}{c}127 . \\
76\end{array}$ & $58 * 47 * 32$ & $\begin{array}{l}5 \mathrm{~PB} 5 / 2- \\
5 \mathrm{~PB} 7 / 2\end{array}$ & $\begin{array}{c}\text { Homogen } \\
\text { eous }\end{array}$ & N-P & & $\begin{array}{c}\text { Primar } \\
\text { y }\end{array}$ & $\begin{array}{c}\text { Cortex } \\
\text { Dominant }\end{array}$ & $\begin{array}{c}\text { Milk } \\
\text { y }\end{array}$ & Opaque & Coarse-Medium & $\begin{array}{l}\text { Non- } \\
\text { Foliat } \\
\text { ed }\end{array}$ \\
\hline
\end{tabular}




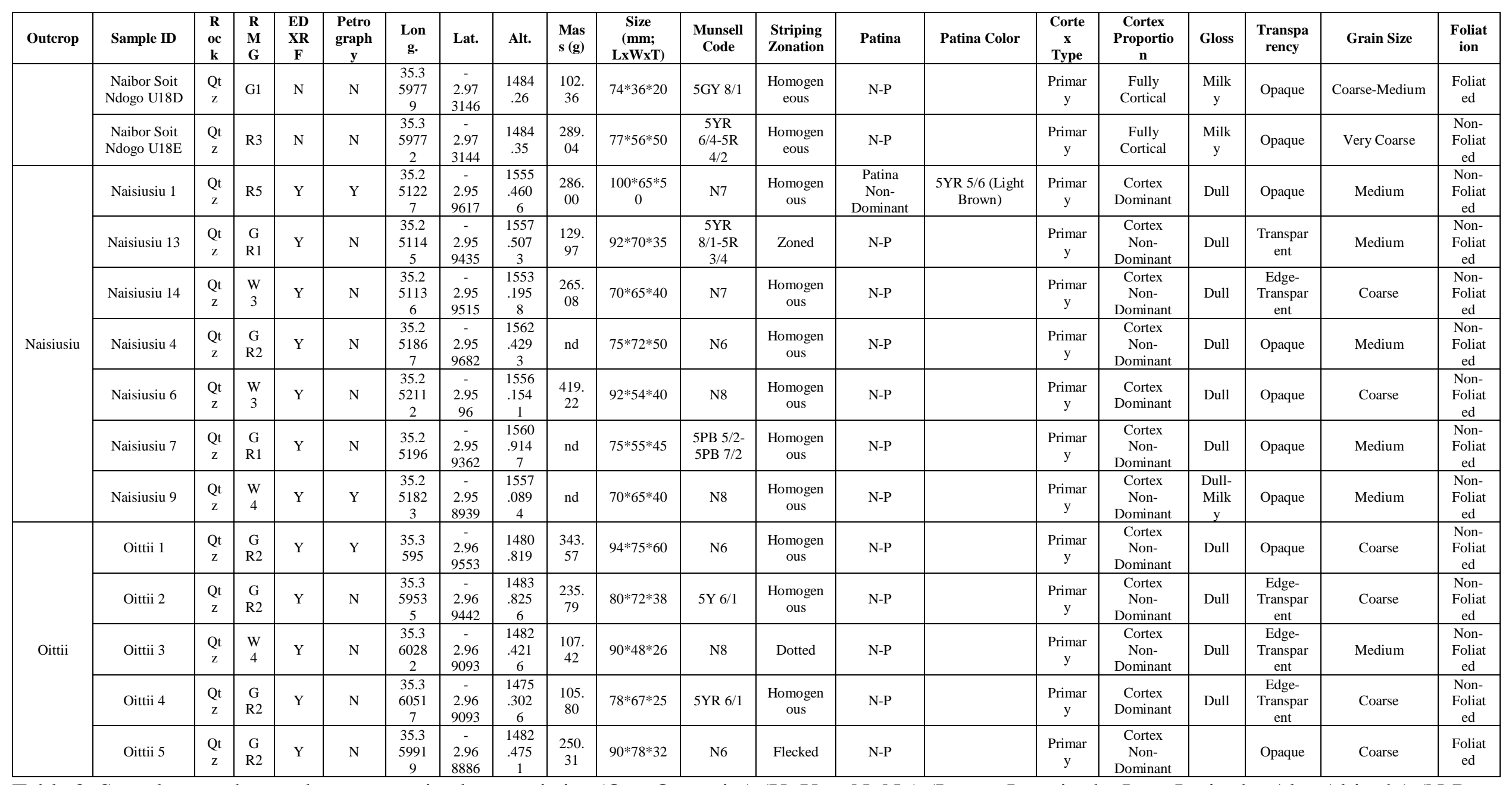

Table 2. Sample metadata and macroscopic characteristics (Qtz: Quartzite) (Y: Yes; N: No) (Long.: Longitude; Lat.: Latitude; Alt.: Altitude) (N-P: Non-Patinated) (Uncons.: Unconsolidated). 


\begin{tabular}{|c|c|c|c|c|c|c|c|c|c|c|c|c|c|c|c|c|c|c|c|}
\hline & \multirow[b]{2}{*}{ STD * } & \multicolumn{8}{|c|}{ weight (\%) } & \multicolumn{10}{|c|}{ ppm } \\
\hline & & MgO & $\mathbf{A l}_{2} \mathbf{O}_{3}$ & $\underset{* *}{\mathrm{SiO}_{2}}$ & $\mathbf{K}_{2} \mathbf{O}$ & $\mathrm{CaO}$ & $\mathrm{TiO}_{2}$ & MnO & $\mathrm{Fe}_{2} \mathrm{O}_{3}$ & $\mathbf{C u}$ & $\mathbf{Z n}$ & $\mathbf{R b}$ & $\mathbf{S r}$ & $\mathbf{Y}$ & $\mathbf{Z r}$ & $\mathbf{N b}$ & $\mathbf{B a}$ & $\mathbf{P b}$ & Th \\
\hline $\begin{array}{c}\text { Endonyo Osunyai } 2 \\
\text { (W3) }\end{array}$ & STD-3 & 0.35 & 3.51 & $\begin{array}{c}105.0 \\
8 \\
\end{array}$ & 0.08 & 0.11 & 0.03 & 0.00 & 0.27 & 3.10 & 1.89 & 0.12 & 5.63 & 3.42 & 62.94 & 0.00 & 22.47 & 1.39 & 1.37 \\
\hline $\begin{array}{c}\text { Endonyo Osunyai } 3 \\
\text { (R3) }\end{array}$ & STD-3 & 0.36 & 4.03 & 88.74 & 0.55 & 0.12 & 0.03 & 0.00 & 0.26 & 2.87 & 0.93 & 19.40 & 32.12 & 0.64 & 22.89 & 0.18 & 308.16 & 4.59 & 0.40 \\
\hline $\begin{array}{c}\text { Endonyo Osunyai } 4 \\
\text { (GR2) }\end{array}$ & STD-3 & 0.63 & 6.81 & 79.47 & 1.80 & 0.12 & 0.11 & 0.00 & 0.84 & 10.42 & 5.60 & 90.57 & 89.03 & 3.98 & 99.49 & 3.72 & 636.92 & 11.29 & 10.80 \\
\hline $\begin{array}{c}\text { Endonyo Osunyai } 5 \\
\text { (GR2) }\end{array}$ & STD-3 & 0.71 & 7.95 & 84.70 & 1.67 & 2.62 & 0.16 & 0.00 & 1.17 & 5.80 & 3.68 & 86.60 & 28.70 & 2.30 & 46.00 & 4.82 & 504.81 & 2.40 & 1.44 \\
\hline $\begin{array}{c}\text { Naibor Soit Ndogo } \\
13 \text { (W3) } \\
\end{array}$ & STD-2 & 0.25 & 2.76 & $\begin{array}{c}104.1 \\
9\end{array}$ & -0.07 & 0.10 & 0.02 & 0.00 & 0.26 & 2.71 & 1.12 & -3.55 & 1.62 & 3.51 & 16.33 & 0.13 & 40.66 & 0.34 & 1.80 \\
\hline $\begin{array}{c}\text { Naibor Soit Ndogo } \\
13 \text { (W3) } \\
\end{array}$ & STD-1 & 0.33 & 3.40 & 79.16 & 0.07 & 0.09 & 0.02 & 0.00 & 0.27 & 2.92 & 2.21 & 0.62 & 3.49 & 11.11 & 20.92 & 0.00 & 62.80 & 0.69 & 1.76 \\
\hline $\begin{array}{c}\text { Naibor Soit Ndogo } \\
14 \text { (W3) }\end{array}$ & STD-2 & 0.31 & 3.10 & 98.71 & 0.00 & 0.09 & 0.03 & 0.00 & 0.25 & 2.86 & 1.50 & -0.94 & 1.47 & 3.71 & 24.49 & 0.00 & 51.06 & 0.00 & 0.96 \\
\hline $\begin{array}{c}\text { Naibor Soit Ndogo } \\
14 \text { (W3) }\end{array}$ & STD-1 & 0.31 & 2.93 & 85.84 & -0.05 & 0.10 & 0.01 & 0.01 & 0.24 & 2.40 & 1.05 & -2.68 & 1.74 & 1.56 & 10.53 & 0.00 & 41.51 & 0.31 & 2.14 \\
\hline $\begin{array}{c}\text { Naibor Soit Ndogo } \\
15(\mathrm{~W} 3) \\
\end{array}$ & STD-2 & 0.29 & 3.05 & $\begin{array}{c}102.7 \\
3 \\
\end{array}$ & -0.02 & 0.10 & 0.02 & 0.00 & 0.24 & 3.35 & 1.64 & -2.25 & 1.99 & 2.02 & 18.77 & 0.57 & 13.27 & 0.74 & 2.03 \\
\hline $\begin{array}{c}\text { Naibor Soit Ndogo } \\
15(\mathrm{~W} 3)\end{array}$ & STD-1 & 0.32 & 3.36 & $\begin{array}{c}104.3 \\
9\end{array}$ & 0.05 & 0.10 & 0.03 & 0.00 & 0.25 & 4.32 & 1.48 & -0.65 & 2.99 & 2.87 & 23.48 & 0.75 & 19.63 & 0.00 & 0.67 \\
\hline $\begin{array}{c}\text { Naibor Soit Ndogo } 6 \\
\text { (W3) }\end{array}$ & STD-2 & 0.30 & 3.00 & $\begin{array}{c}104.8 \\
4 \\
\end{array}$ & -0.04 & 0.09 & 0.01 & 0.00 & 0.25 & 2.84 & 1.04 & -2.88 & 1.77 & 2.87 & 21.81 & 0.00 & 148.50 & 0.55 & 0.43 \\
\hline $\begin{array}{c}\text { Naibor Soit Ndogo } 6 \\
\text { (W3) }\end{array}$ & STD-1 & 0.42 & 3.25 & 15.76 & -0.02 & 0.09 & 0.02 & 0.02 & 0.24 & 2.58 & 1.39 & -2.36 & 0.72 & 2.06 & 20.09 & 0.00 & 196.42 & 0.36 & 1.67 \\
\hline $\begin{array}{c}\text { Naibor Soit Ndogo } 8 \\
\text { (W3) }\end{array}$ & STD-2 & 0.31 & 3.54 & $\begin{array}{c}100.2 \\
3 \\
\end{array}$ & 0.09 & 0.09 & 0.02 & 0.00 & 0.25 & 3.47 & 1.72 & 1.15 & 2.85 & 2.67 & 19.45 & 0.00 & 86.41 & 0.49 & 0.15 \\
\hline $\begin{array}{l}\text { Naibor Soit Ndogo } 8 \\
\text { (W3) }\end{array}$ & STD-1 & 0.30 & 3.13 & $\begin{array}{c}102.4 \\
9\end{array}$ & 0.01 & 0.14 & 0.01 & 0.00 & 0.24 & 3.35 & 1.61 & -2.55 & 6.63 & 2.35 & 23.78 & 0.00 & 42.80 & 0.57 & 0.73 \\
\hline $\begin{array}{c}\text { Naibor Soit Kubwa } 1 \\
(\mathrm{R} 3)\end{array}$ & STD-3 & 0.28 & 3.06 & 97.40 & 0.00 & 0.10 & 0.01 & 0.00 & 0.24 & 2.99 & 0.73 & -0.13 & 6.16 & 3.00 & 33.48 & 0.47 & 19.41 & 0.86 & 2.30 \\
\hline $\begin{array}{c}\text { Naibor Soit Kubwa } \\
11(\mathrm{~W} 3) \\
\end{array}$ & STD-1 & 0.33 & 3.03 & 83.86 & -0.06 & 0.09 & 0.01 & 0.00 & 0.24 & 2.28 & 0.65 & -2.41 & 1.78 & 4.78 & 39.62 & 0.00 & 0.41 & 0.69 & 1.30 \\
\hline $\begin{array}{c}\text { Naibor Soit Kubwa } \\
13(\mathrm{R} 3) \\
\end{array}$ & STD-1 & 0.34 & 3.30 & 93.06 & -0.01 & 0.10 & 0.02 & 0.00 & 0.26 & 2.63 & 0.74 & -2.66 & 3.56 & 2.61 & 19.86 & 0.00 & 27.29 & 0.14 & 1.02 \\
\hline $\begin{array}{c}\text { Naibor Soit Kubwa } \\
\text { 14A(W2) }\end{array}$ & STD-3 & 0.29 & 3.31 & 96.26 & 0.01 & 0.10 & 0.02 & 0.00 & 0.23 & 1.72 & 0.38 & -0.66 & 12.69 & 4.89 & 23.25 & 0.25 & 10.58 & 1.18 & 0.56 \\
\hline $\begin{array}{c}\text { Naibor Soit Kubwa } 2 \\
\text { (W3) }\end{array}$ & STD-3 & 0.32 & 3.17 & $\begin{array}{c}103.5 \\
2\end{array}$ & 0.01 & 0.11 & 0.02 & 0.00 & 0.26 & 2.20 & 0.16 & -0.18 & 5.30 & 2.25 & 19.48 & 0.46 & 49.35 & 0.62 & 1.53 \\
\hline $\begin{array}{c}\text { Naibor Soit Kubwa } \\
\text { 24A (W2) }\end{array}$ & STD-3 & 0.30 & 2.81 & $\begin{array}{c}102.5 \\
7 \\
\end{array}$ & -0.08 & 0.11 & 0.01 & 0.00 & 0.24 & 4.72 & 0.26 & -3.29 & 5.97 & 2.26 & 30.84 & 0.00 & 23.89 & 0.00 & 5.23 \\
\hline $\begin{array}{c}\text { Naibor Soit Kubwa } \\
27 \text { (R3) } \\
\end{array}$ & STD-1 & 0.44 & 4.75 & 98.08 & 0.29 & 0.11 & 0.03 & 0.00 & 0.30 & 4.01 & 0.78 & 9.78 & 8.87 & 5.74 & 45.70 & 0.10 & 101.52 & 1.46 & 1.20 \\
\hline $\begin{array}{c}\text { Naibor Soit Kubwa } \\
\text { 31A (G1) } \\
\end{array}$ & STD-3 & 0.33 & 3.25 & $\begin{array}{c}103.3 \\
4 \\
\end{array}$ & 0.02 & 0.09 & 0.03 & 0.00 & 0.26 & 3.18 & 0.17 & -0.74 & 2.04 & 2.27 & 26.85 & 0.00 & 14.62 & 0.41 & 0.92 \\
\hline $\begin{array}{c}\text { Naibor Soit Kubwa } \\
\text { 33A (GR1) }\end{array}$ & STD-3 & 0.32 & 2.95 & 85.54 & -0.05 & 0.09 & 0.01 & 0.00 & 0.24 & 3.27 & 0.37 & -2.93 & 0.80 & 4.15 & 15.12 & 0.00 & 31.78 & 0.00 & 0.86 \\
\hline Naisiusiu 1 (R6) & STD-2 & 0.42 & 4.59 & 97.50 & 0.12 & 0.16 & 0.06 & 0.00 & 0.54 & 7.37 & 3.98 & 3.09 & 34.78 & 14.91 & 58.39 & 0.00 & 146.27 & 3.55 & 3.18 \\
\hline Naisiusiu 1 (R6) & STD-1 & 0.45 & 5.24 & 94.41 & 0.28 & 0.22 & 0.12 & 0.01 & 0.71 & 6.70 & 5.52 & 7.79 & 59.35 & 20.32 & 76.91 & 0.52 & 257.12 & 5.79 & 2.50 \\
\hline
\end{tabular}




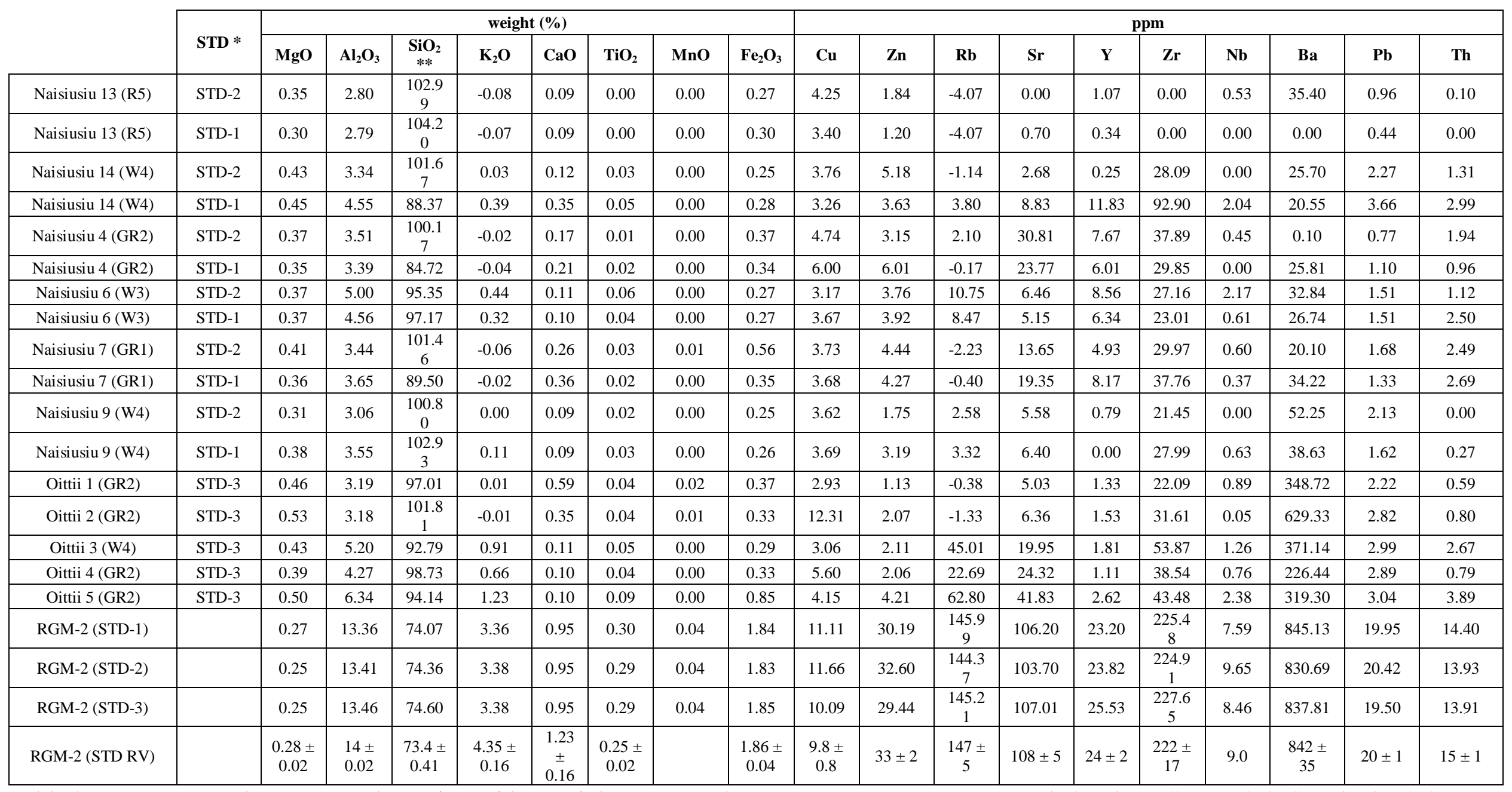

1 Table 3. Raw EDXRF data per sample (major oxides: weight \%; trace elements: ppm) (RV: Recommended Value) (STD-1-2-3: Standard 1-2-3).

$2 *$ Sample data normalized according to which RGM-2 STD values.

$3 * *$ Some $\mathrm{SiO}_{2}$ values are off the upper end of the calibration standard.

$4 \quad$ Negative values are below detection limits. 


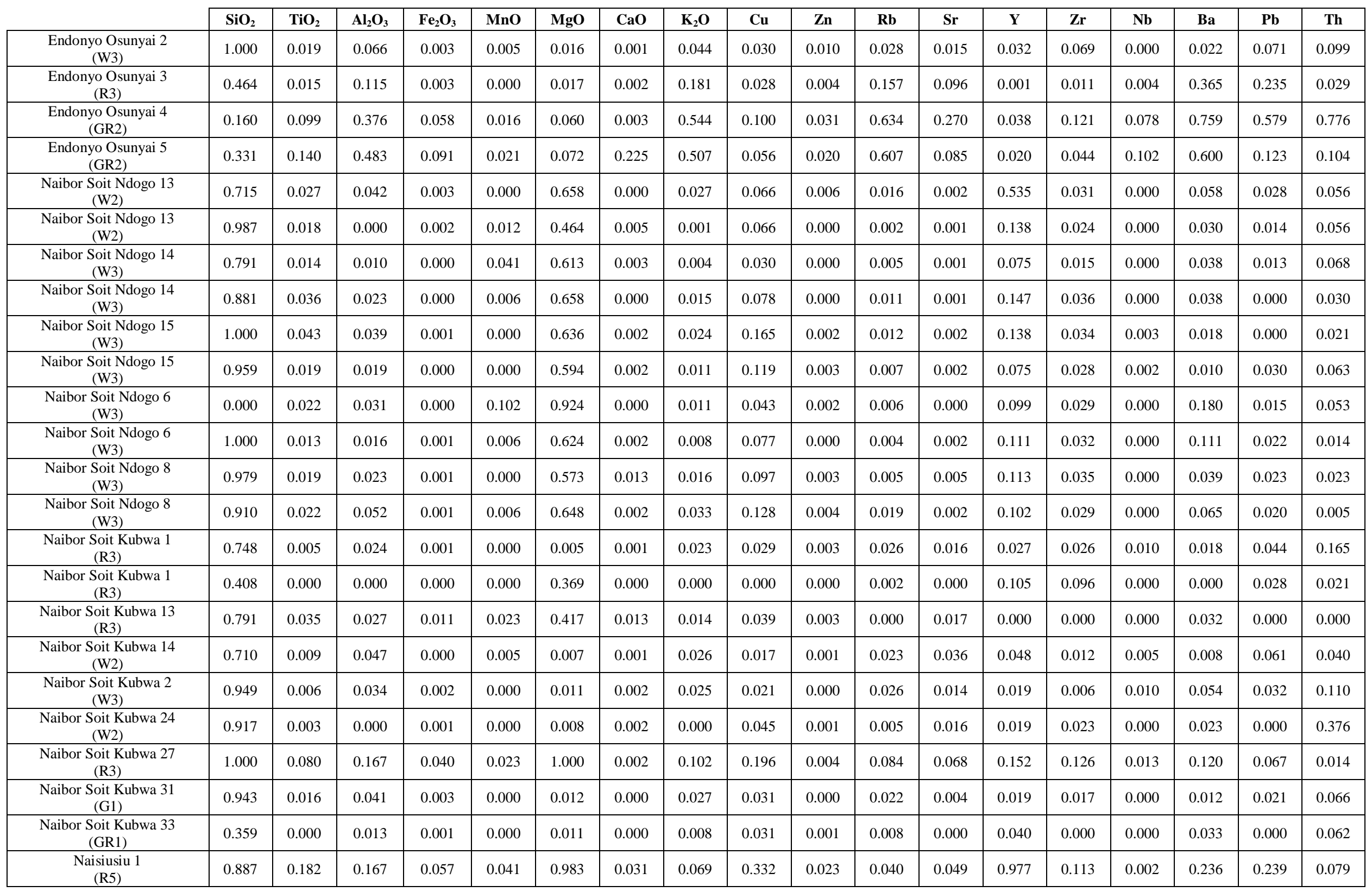




\begin{tabular}{|c|c|c|c|c|c|c|c|c|c|c|c|c|c|c|c|c|c|c|}
\hline & $\mathrm{SiO}_{2}$ & $\mathrm{TiO}_{2}$ & $\mathbf{A l}_{2} \mathbf{O}_{3}$ & $\mathrm{Fe}_{2} \mathrm{O}_{3}$ & $\mathrm{MnO}$ & MgO & $\mathrm{CaO}$ & $\mathrm{K}_{2} \mathrm{O}$ & $\mathrm{Cu}$ & $\mathbf{Z n}$ & $\mathbf{R b}$ & $\mathrm{Sr}$ & $\mathbf{Y}$ & $\mathbf{Z r}$ & $\mathbf{N b}$ & Ba & $\mathbf{P b}$ & Th \\
\hline $\begin{array}{l}\text { Naisiusiu } 1 \\
\text { (R5) }\end{array}$ & 0.857 & 0.077 & 0.122 & 0.033 & 0.000 & 0.964 & 0.025 & 0.039 & 0.449 & 0.015 & 0.026 & 0.030 & 0.622 & 0.087 & 0.000 & 0.110 & 0.144 & 0.099 \\
\hline $\begin{array}{c}\text { Naisiusiu } 13 \\
\text { (GR1) }\end{array}$ & 0.998 & 0.000 & 0.000 & 0.007 & 0.007 & 0.579 & 0.001 & 0.000 & 0.100 & 0.001 & 0.000 & 0.000 & 0.016 & 0.000 & 0.000 & 0.000 & 0.018 & 0.000 \\
\hline $\begin{array}{c}\begin{array}{c}\text { Naisiusiu } 13 \\
\text { (GR1) }\end{array} \\
\end{array}$ & 0.964 & 0.000 & 0.002 & 0.003 & 0.006 & 0.779 & 0.001 & 0.000 & 0.193 & 0.004 & 0.000 & 0.000 & 0.034 & 0.000 & 0.002 & 0.026 & 0.039 & 0.003 \\
\hline $\begin{array}{l}\text { Naisiusiu } 14 \\
\text { (W3) }\end{array}$ & 0.819 & 0.076 & 0.120 & 0.006 & 0.014 & 1.000 & 0.063 & 0.090 & 0.091 & 0.013 & 0.027 & 0.007 & 0.569 & 0.136 & 0.008 & 0.019 & 0.151 & 0.095 \\
\hline $\begin{array}{l}\text { Naisiusiu } 14 \\
\text { (W3) }\end{array}$ & 0.938 & 0.034 & 0.039 & 0.001 & 0.000 & 1.000 & 0.011 & 0.021 & 0.152 & 0.021 & 0.011 & 0.002 & 0.000 & 0.042 & 0.000 & 0.019 & 0.092 & 0.041 \\
\hline $\begin{array}{c}\text { Naisiusiu } 4 \\
\text { (GR2) }\end{array}$ & 0.778 & 0.025 & 0.041 & 0.013 & 0.007 & 0.701 & 0.029 & 0.007 & 0.282 & 0.026 & 0.013 & 0.019 & 0.289 & 0.044 & 0.000 & 0.024 & 0.045 & 0.031 \\
\hline $\begin{array}{c}\text { Naisiusiu } 4 \\
\text { (GR2) }\end{array}$ & 0.909 & 0.012 & 0.050 & 0.014 & 0.006 & 0.821 & 0.029 & 0.012 & 0.233 & 0.011 & 0.023 & 0.027 & 0.315 & 0.056 & 0.002 & 0.000 & 0.031 & 0.060 \\
\hline $\begin{array}{l}\text { Naisiusiu } 6 \\
\text { (W3) }\end{array}$ & 0.919 & 0.056 & 0.121 & 0.004 & 0.014 & 0.757 & 0.003 & 0.076 & 0.119 & 0.015 & 0.042 & 0.004 & 0.305 & 0.034 & 0.002 & 0.025 & 0.062 & 0.079 \\
\hline $\begin{array}{c}\text { Naisiusiu } 6 \\
\text { (W3) }\end{array}$ & 0.816 & 0.088 & 0.149 & 0.003 & 0.019 & 0.812 & 0.006 & 0.100 & 0.103 & 0.014 & 0.054 & 0.006 & 0.352 & 0.040 & 0.008 & 0.025 & 0.061 & 0.035 \\
\hline $\begin{array}{c}\text { Naisiusiu } 7 \\
(\text { GR1 })\end{array}$ & 0.832 & 0.029 & 0.059 & 0.014 & 0.027 & 0.751 & 0.065 & 0.009 & 0.120 & 0.017 & 0.012 & 0.016 & 0.393 & 0.055 & 0.001 & 0.031 & 0.055 & 0.085 \\
\hline $\begin{array}{c}\text { Naisiusiu } 9 \\
\text { (W4) }\end{array}$ & 0.984 & 0.046 & 0.052 & 0.003 & 0.007 & 0.811 & 0.001 & 0.035 & 0.120 & 0.011 & 0.025 & 0.005 & 0.000 & 0.041 & 0.002 & 0.035 & 0.067 & 0.008 \\
\hline $\begin{array}{c}\text { Naisiusiu } 9 \\
\text { (W4) }\end{array}$ & 0.921 & 0.018 & 0.020 & 0.001 & 0.006 & 0.630 & 0.000 & 0.015 & 0.141 & 0.004 & 0.024 & 0.005 & 0.023 & 0.032 & 0.000 & 0.039 & 0.086 & 0.000 \\
\hline $\begin{array}{l}\text { Oittii } 1 \\
\text { (GR2) }\end{array}$ & 0.735 & 0.029 & 0.036 & 0.013 & 0.091 & 0.033 & 0.044 & 0.026 & 0.028 & 0.006 & 0.025 & 0.013 & 0.009 & 0.010 & 0.019 & 0.413 & 0.114 & 0.042 \\
\hline $\begin{array}{c}\text { Oittii } 2 \\
\text { (GR2) }\end{array}$ & 0.893 & 0.027 & 0.034 & 0.009 & 0.070 & 0.043 & 0.023 & 0.021 & 0.118 & 0.011 & 0.018 & 0.017 & 0.011 & 0.024 & 0.001 & 0.750 & 0.144 & 0.058 \\
\hline $\begin{array}{l}\text { Oittii } 3 \\
\text { (W4) }\end{array}$ & 0.597 & 0.036 & 0.224 & 0.005 & 0.005 & 0.029 & 0.001 & 0.284 & 0.029 & 0.011 & 0.329 & 0.059 & 0.014 & 0.056 & 0.026 & 0.440 & 0.153 & 0.192 \\
\hline $\begin{array}{l}\text { Oittii } 4 \\
\text { (GR2) }\end{array}$ & 0.791 & 0.031 & 0.138 & 0.009 & 0.021 & 0.022 & 0.001 & 0.214 & 0.054 & 0.011 & 0.179 & 0.072 & 0.006 & 0.034 & 0.016 & 0.266 & 0.148 & 0.057 \\
\hline $\begin{array}{l}\text { Oittii } 5 \\
\text { (GR2) }\end{array}$ & 0.641 & 0.075 & 0.331 & 0.060 & 0.000 & 0.039 & 0.001 & 0.378 & 0.040 & 0.023 & 0.448 & 0.125 & 0.023 & 0.041 & 0.050 & 0.378 & 0.156 & 0.280 \\
\hline
\end{tabular}

Table 4. Normalized EDXRF data per sample and RMG. 


\begin{tabular}{|c|c|c|c|c|c|c|c|c|c|c|c|c|c|c|c|c|c|c|}
\hline All Outcrops & & & & & & & & & & & & & & & & & & \\
\hline$\tau / p$ (uncorr.) & $\mathrm{SiO2}$ & TiO2 & Al2O3 & Fe2O3 & MnO & MgO & $\mathrm{CaO}$ & K2O & $\mathrm{Cu}$ & $\mathbf{Z n}$ & $\mathbf{R b}$ & $\mathrm{Sr}$ & $\mathbf{Y}$ & $\mathbf{Z r}$ & $\mathbf{N b}$ & $\mathbf{B a}$ & $\mathbf{P b}$ & Th \\
\hline$\overline{\mathrm{SiO2}}$ & & 0.482 & 0.044 & 0.486 & 0.468 & 0.113 & 0.917 & 0.060 & 0.005 & 0.146 & 0.029 & 0.017 & 0.734 & 0.767 & 0.055 & 0.026 & 0.079 & 0.045 \\
\hline TiO2 & -0.075 & & 0.000 & 0.000 & 0.008 & 0.001 & 0.002 & 0.000 & 0.009 & 0.000 & 0.000 & 0.002 & 0.082 & 0.000 & 0.003 & 0.004 & 0.001 & 0.184 \\
\hline Al2O3 & -0.216 & 0.597 & & 0.000 & 0.156 & 0.101 & 0.035 & 0.000 & 0.278 & 0.000 & 0.000 & 0.000 & 0.273 & 0.000 & 0.000 & 0.003 & 0.000 & 0.008 \\
\hline Fe2O3 & -0.075 & 0.426 & 0.514 & & 0.002 & 0.092 & 0.000 & 0.001 & 0.025 & 0.000 & 0.000 & 0.000 & 0.758 & 0.008 & 0.001 & 0.018 & 0.000 & 0.049 \\
\hline MnO & -0.078 & 0.286 & 0.152 & 0.336 & & 0.017 & 0.001 & 0.805 & 0.223 & 0.039 & 0.638 & 0.432 & 0.393 & 0.378 & 0.208 & 0.039 & 0.200 & 0.543 \\
\hline MgO & 0.170 & 0.357 & 0.176 & 0.181 & 0.257 & & 0.021 & 0.904 & 0.000 & 0.008 & 0.921 & 0.386 & 0.000 & 0.000 & 0.656 & 0.654 & 0.381 & 0.149 \\
\hline $\mathrm{CaO}$ & 0.011 & 0.326 & 0.226 & 0.413 & 0.340 & 0.247 & & 0.620 & 0.011 & 0.000 & 0.453 & 0.008 & 0.052 & 0.035 & 0.115 & 0.512 & 0.038 & 0.102 \\
\hline K2O & -0.201 & 0.507 & 0.760 & 0.349 & 0.026 & 0.013 & 0.053 & & 0.742 & 0.000 & 0.000 & 0.000 & 0.767 & 0.006 & 0.000 & 0.000 & 0.000 & 0.032 \\
\hline $\mathbf{C u}$ & 0.303 & 0.282 & 0.116 & 0.241 & 0.130 & 0.585 & 0.273 & -0.035 & & 0.001 & 0.930 & 0.903 & 0.002 & 0.002 & 0.603 & 0.670 & 0.410 & 0.182 \\
\hline$\overline{Z n}$ & -0.156 & 0.522 & 0.554 & 0.580 & 0.221 & 0.283 & 0.384 & 0.388 & 0.355 & & 0.000 & 0.000 & 0.404 & 0.000 & 0.003 & 0.051 & 0.000 & 0.027 \\
\hline $\mathbf{R b}$ & -0.234 & 0.415 & 0.719 & 0.374 & 0.050 & -0.011 & 0.080 & 0.798 & -0.009 & 0.417 & & 0.000 & 0.991 & 0.003 & 0.000 & 0.001 & 0.000 & 0.002 \\
\hline $\mathbf{S r}$ & -0.256 & 0.329 & 0.570 & 0.533 & 0.084 & -0.093 & 0.285 & 0.503 & 0.013 & 0.425 & 0.593 & & 0.624 & 0.007 & 0.000 & 0.005 & 0.000 & 0.002 \\
\hline $\mathbf{Y}$ & 0.036 & 0.186 & 0.118 & 0.033 & 0.092 & 0.437 & 0.209 & -0.032 & 0.326 & 0.089 & 0.001 & -0.052 & & 0.000 & 0.407 & 0.314 & 0.583 & 0.381 \\
\hline $\mathbf{Z r}$ & -0.032 & 0.487 & 0.453 & 0.286 & 0.094 & 0.380 & 0.225 & 0.293 & 0.325 & 0.426 & 0.314 & 0.288 & 0.373 & & 0.142 & 0.660 & 0.001 & 0.057 \\
\hline $\mathbf{N b}$ & -0.206 & 0.323 & 0.503 & 0.372 & 0.135 & -0.048 & 0.169 & 0.523 & -0.056 & 0.323 & 0.588 & 0.496 & -0.089 & 0.157 & & 0.028 & 0.000 & 0.006 \\
\hline $\mathbf{B a}$ & -0.239 & 0.306 & 0.315 & 0.254 & 0.221 & -0.048 & 0.070 & 0.408 & -0.046 & 0.209 & 0.351 & 0.300 & -0.108 & 0.047 & 0.235 & & 0.005 & 0.260 \\
\hline $\mathbf{P b}$ & -0.188 & 0.363 & 0.541 & 0.439 & 0.137 & 0.094 & 0.223 & 0.498 & 0.088 & 0.554 & 0.572 & 0.528 & -0.059 & 0.365 & 0.481 & 0.302 & & 0.013 \\
\hline Th & -0.215 & 0.143 & 0.286 & 0.211 & -0.065 & -0.154 & 0.175 & 0.230 & -0.143 & 0.237 & 0.340 & 0.330 & 0.094 & 0.204 & 0.297 & 0.121 & 0.267 & \\
\hline
\end{tabular}

Table 5. Correlations [ $\tau$ / p (uncorr.] for EDXRF data for all samples based on Kendall's Tau coefficient. 


\begin{tabular}{|c|c|c|c|c|c|c|c|c|c|c|c|c|c|c|c|c|c|c|}
\hline All Outcrops & & & & & & & & & & & & & & & & & & \\
\hline p Permutations & SiO2 & TiO2 & Al2O3 & Fe2O3 & MnO & MgO & $\mathrm{CaO}$ & K2O & $\mathbf{C u}$ & $\mathbf{Z n}$ & $\mathbf{R b}$ & $\mathbf{S r}$ & $\mathbf{Y}$ & $\mathbf{Z r}$ & Nb & Ba & $\mathbf{P b}$ & Th \\
\hline $\mathrm{SiO2}$ & & 0.494 & 0.046 & 0.508 & 0.494 & 0.121 & 0.928 & 0.063 & 0.005 & 0.162 & 0.028 & 0.019 & 0.738 & 0.775 & 0.082 & 0.026 & 0.085 & 0.044 \\
\hline TiO2 & 0.494 & & 0.000 & 0.000 & 0.011 & 0.001 & 0.004 & 0.000 & 0.009 & 0.000 & 0.000 & 0.002 & 0.090 & 0.000 & 0.007 & 0.004 & 0.001 & 0.195 \\
\hline $\mathrm{Al203}$ & 0.046 & 0.000 & & 0.000 & 0.184 & 0.107 & 0.044 & 0.000 & 0.290 & 0.000 & 0.000 & 0.000 & 0.292 & 0.000 & 0.000 & 0.003 & 0.000 & 0.008 \\
\hline Fe2O3 & 0.508 & 0.000 & 0.000 & & 0.004 & 0.111 & 0.000 & 0.003 & 0.027 & 0.000 & 0.001 & 0.000 & 0.776 & 0.008 & 0.002 & 0.023 & 0.000 & 0.057 \\
\hline MnO & 0.494 & 0.011 & 0.184 & 0.004 & & 0.024 & 0.002 & 0.819 & 0.257 & 0.057 & 0.662 & 0.472 & 0.423 & 0.407 & 0.277 & 0.051 & 0.228 & 0.565 \\
\hline MgO & 0.121 & 0.001 & 0.107 & 0.111 & 0.024 & & 0.027 & 0.914 & 0.000 & 0.010 & 0.931 & 0.406 & 0.000 & 0.001 & 0.691 & 0.660 & 0.394 & 0.153 \\
\hline $\mathrm{CaO}$ & 0.928 & 0.004 & 0.044 & 0.000 & 0.002 & 0.027 & & 0.641 & 0.014 & 0.001 & 0.489 & 0.012 & 0.062 & 0.045 & 0.158 & 0.540 & 0.051 & 0.123 \\
\hline K2O & 0.063 & 0.000 & 0.000 & 0.003 & 0.819 & 0.914 & 0.641 & & 0.757 & 0.001 & 0.000 & 0.000 & 0.780 & 0.007 & 0.000 & 0.000 & 0.000 & 0.034 \\
\hline $\mathbf{C u}$ & 0.005 & 0.009 & 0.290 & 0.027 & 0.257 & 0.000 & 0.014 & 0.757 & & 0.001 & 0.940 & 0.909 & 0.002 & 0.002 & 0.649 & 0.680 & 0.426 & 0.186 \\
\hline $\mathbf{Z n}$ & 0.162 & 0.000 & 0.000 & 0.000 & 0.057 & 0.010 & 0.001 & 0.001 & 0.001 & & 0.000 & 0.000 & 0.418 & 0.000 & 0.006 & 0.058 & 0.000 & 0.033 \\
\hline $\mathbf{R b}$ & 0.028 & 0.000 & 0.000 & 0.001 & 0.662 & 0.931 & 0.489 & 0.000 & 0.940 & 0.000 & & 0.000 & 0.999 & 0.003 & 0.000 & 0.001 & 0.000 & 0.001 \\
\hline $\mathrm{Sr}$ & 0.019 & 0.002 & 0.000 & 0.000 & 0.472 & 0.406 & 0.012 & 0.000 & 0.909 & 0.000 & 0.000 & & 0.642 & 0.008 & 0.000 & 0.006 & 0.000 & 0.002 \\
\hline $\mathbf{Y}$ & 0.738 & 0.090 & 0.292 & 0.776 & 0.423 & 0.000 & 0.062 & 0.780 & 0.002 & 0.418 & 0.999 & 0.642 & & 0.000 & 0.452 & 0.333 & 0.597 & 0.397 \\
\hline $\mathbf{Z r}$ & 0.775 & 0.000 & 0.000 & 0.008 & 0.407 & 0.001 & 0.045 & 0.007 & 0.002 & 0.000 & 0.003 & 0.008 & 0.000 & & 0.181 & 0.663 & 0.001 & 0.062 \\
\hline $\mathbf{N b}$ & 0.082 & 0.007 & 0.000 & 0.002 & 0.277 & 0.691 & 0.158 & 0.000 & 0.649 & 0.006 & 0.000 & 0.000 & 0.452 & 0.181 & & 0.046 & 0.000 & 0.011 \\
\hline Ba & 0.026 & 0.004 & 0.003 & 0.023 & 0.051 & 0.660 & 0.540 & 0.000 & 0.680 & 0.058 & 0.001 & 0.006 & 0.333 & 0.663 & 0.046 & & 0.005 & 0.276 \\
\hline $\mathbf{P b}$ & 0.085 & 0.001 & 0.000 & 0.000 & 0.228 & 0.394 & 0.051 & 0.000 & 0.426 & 0.000 & 0.000 & 0.000 & 0.597 & 0.001 & 0.000 & 0.005 & & 0.013 \\
\hline Th & 0.044 & 0.195 & 0.008 & 0.057 & 0.565 & 0.153 & 0.123 & 0.034 & 0.186 & 0.033 & 0.001 & 0.002 & 0.397 & 0.062 & 0.011 & 0.276 & 0.013 & \\
\hline
\end{tabular}

Table 6. Correlations [p (uncorr.] for EDXRF data for all samples based on Kendall's Tau Monte Carlo simulations. 


\begin{tabular}{|c|c|c|c|c|c|c|c|c|c|c|c|c|c|c|c|c|c|c|}
\hline Endonyo Osunyai & & & & & & & & & & & & & & & & & & \\
\hline$\tau / \mathbf{p}$ (uncorr.) & $\mathrm{SiO2}$ & TiO2 & Al2O3 & Fe2O3 & MnO & MgO & $\mathrm{CaO}$ & K2O & $\mathbf{C u}$ & Zn & $\mathbf{R b}$ & $\mathbf{S r}$ & $\mathbf{Y}$ & $\mathbf{Z r}$ & $\mathbf{N b}$ & $\mathbf{B a}$ & $\mathbf{P b}$ & Th \\
\hline $\mathrm{SiO2}$ & & 0.497 & 0.174 & 0.264 & 0.497 & 0.174 & 0.174 & 0.042 & 0.174 & 0.174 & 0.042 & 0.174 & 0.497 & 0.497 & 0.174 & 0.042 & 0.174 & 0.174 \\
\hline TiO2 & -0.333 & & 0.174 & 0.063 & 0.042 & 0.174 & 0.174 & 0.497 & 0.174 & 0.174 & 0.497 & 1.000 & 0.497 & 0.497 & 0.174 & 0.497 & 1.000 & 0.174 \\
\hline $\mathrm{Al2O3}$ & -0.667 & 0.667 & & 0.063 & 0.174 & 0.042 & 0.042 & 0.174 & 0.497 & 0.497 & 0.174 & 0.497 & 1.000 & 1.000 & 0.042 & 0.174 & 0.497 & 0.497 \\
\hline Fe2O3 & -0.548 & 0.913 & 0.913 & & 0.063 & 0.063 & 0.063 & 0.264 & 0.264 & 0.264 & 0.264 & 0.710 & 0.710 & 0.710 & 0.063 & 0.264 & 0.710 & 0.264 \\
\hline MnO & -0.333 & 1.000 & 0.667 & 0.913 & & 0.174 & 0.174 & 0.497 & 0.174 & 0.174 & 0.497 & 1.000 & 0.497 & 0.497 & 0.174 & 0.497 & 1.000 & 0.174 \\
\hline MgO & -0.667 & 0.667 & 1.000 & 0.913 & 0.667 & & 0.042 & 0.174 & 0.497 & 0.497 & 0.174 & 0.497 & 1.000 & 1.000 & 0.042 & 0.174 & 0.497 & 0.497 \\
\hline $\mathrm{CaO}$ & -0.667 & 0.667 & 1.000 & 0.913 & 0.667 & 1.000 & & 0.174 & 0.497 & 0.497 & 0.174 & 0.497 & 1.000 & 1.000 & 0.042 & 0.174 & 0.497 & 0.497 \\
\hline K2O & -1.000 & 0.333 & 0.667 & 0.548 & 0.333 & 0.667 & 0.667 & & 0.174 & 0.174 & 0.042 & 0.174 & 0.497 & 0.497 & 0.174 & 0.042 & 0.174 & 0.174 \\
\hline $\mathbf{Z n}$ & -0.667 & 0.667 & 0.333 & 0.548 & 0.667 & 0.333 & 0.333 & 0.667 & 1.000 & & 0.174 & 0.497 & 0.174 & 0.174 & 0.497 & 0.174 & 0.497 & 0.042 \\
\hline $\mathbf{R b}$ & -1.000 & 0.333 & 0.667 & 0.548 & 0.333 & 0.667 & 0.667 & 1.000 & 0.667 & 0.667 & & 0.174 & 0.497 & 0.497 & 0.174 & 0.042 & 0.174 & 0.174 \\
\hline $\mathbf{S r}$ & -0.667 & 0.000 & 0.333 & 0.183 & 0.000 & 0.333 & 0.333 & 0.667 & 0.333 & 0.333 & 0.667 & & 1.000 & 1.000 & 0.497 & 0.174 & 0.042 & 0.497 \\
\hline $\mathbf{Y}$ & -0.333 & 0.333 & 0.000 & 0.183 & 0.333 & 0.000 & 0.000 & 0.333 & 0.667 & 0.667 & 0.333 & 0.000 & & 0.042 & 1.000 & 0.497 & 1.000 & 0.174 \\
\hline $\mathbf{Z r}$ & -0.333 & 0.333 & 0.000 & 0.183 & 0.333 & 0.000 & 0.000 & 0.333 & 0.667 & 0.667 & 0.333 & 0.000 & 1.000 & & 1.000 & 0.497 & 1.000 & 0.174 \\
\hline $\mathbf{N b}$ & -0.667 & 0.667 & 1.000 & 0.913 & 0.667 & 1.000 & 1.000 & 0.667 & 0.333 & 0.333 & 0.667 & 0.333 & 0.000 & 0.000 & & 0.174 & 0.497 & 0.497 \\
\hline $\mathbf{B a}$ & -1.000 & 0.333 & 0.667 & 0.548 & 0.333 & 0.667 & 0.667 & 1.000 & 0.667 & 0.667 & 1.000 & 0.667 & 0.333 & 0.333 & 0.667 & & 0.174 & 0.174 \\
\hline $\mathbf{P b}$ & -0.667 & 0.000 & 0.333 & 0.183 & 0.000 & 0.333 & 0.333 & 0.667 & 0.333 & 0.333 & 0.667 & 1.000 & 0.000 & 0.000 & 0.333 & 0.667 & & 0.497 \\
\hline Th & -0.667 & 0.667 & 0.333 & 0.548 & 0.667 & 0.333 & 0.333 & 0.667 & 1.000 & 1.000 & 0.667 & 0.333 & 0.667 & 0.667 & 0.333 & 0.667 & 0.333 & \\
\hline
\end{tabular}

Table 7. Correlations [ $\tau$ / p (uncorr.] for EDXRF data for Endonyo Osunyai based on Kendall's Tau coefficient. 


\begin{tabular}{|c|c|c|c|c|c|c|c|c|c|c|c|c|c|c|c|c|c|c|}
\hline Endonyo Osunyai & & & & & & & & & & & & & & & & & & \\
\hline p Permutations & $\mathrm{SiO2}$ & TiO2 & $\mathrm{Al203}$ & Fe2O3 & MnO & MgO & $\mathrm{CaO}$ & K2O & $\mathbf{C u}$ & $\mathbf{Z n}$ & $\mathbf{R b}$ & $\mathbf{S r}$ & $\mathbf{Y}$ & $\mathbf{Z r}$ & $\mathbf{N b}$ & $\mathbf{B a}$ & $\mathbf{P b}$ & Th \\
\hline $\mathrm{SiO2}$ & & 0.747 & 0.332 & 0.494 & 0.739 & 0.326 & 0.329 & 0.087 & 0.338 & 0.338 & 0.083 & 0.338 & 0.751 & 0.749 & 0.333 & 0.086 & 0.334 & 0.336 \\
\hline TiO2 & 0.747 & & 0.344 & 0.170 & 0.077 & 0.332 & 0.324 & 0.752 & 0.330 & 0.338 & 0.747 & 1.000 & 0.753 & 0.750 & 0.335 & 0.747 & 1.000 & 0.331 \\
\hline $\mathrm{Al2O3}$ & 0.332 & 0.344 & & 0.166 & 0.331 & 0.081 & 0.081 & 0.332 & 0.747 & 0.756 & 0.334 & 0.759 & 1.000 & 1.000 & 0.085 & 0.338 & 0.745 & 0.747 \\
\hline Fe2O3 & 0.494 & 0.170 & 0.166 & & 0.170 & 0.160 & 0.168 & 0.501 & 0.502 & 0.499 & 0.507 & 1.000 & 1.000 & 1.000 & 0.172 & 0.509 & 1.000 & 0.486 \\
\hline MnO & 0.739 & 0.077 & 0.331 & 0.170 & & 0.329 & 0.336 & 0.750 & 0.340 & 0.342 & 0.750 & 1.000 & 0.752 & 0.747 & 0.341 & 0.750 & 1.000 & 0.336 \\
\hline $\mathrm{MgO}$ & 0.326 & 0.332 & 0.081 & 0.160 & 0.329 & & 0.085 & 0.335 & 0.748 & 0.743 & 0.337 & 0.757 & 1.000 & 1.000 & 0.083 & 0.336 & 0.740 & 0.752 \\
\hline $\mathrm{CaO}$ & 0.329 & 0.324 & 0.081 & 0.168 & 0.336 & 0.085 & & 0.331 & 0.747 & 0.751 & 0.326 & 0.753 & 1.000 & 1.000 & 0.084 & 0.330 & 0.754 & 0.751 \\
\hline K2O & 0.087 & 0.752 & 0.332 & 0.501 & 0.750 & 0.335 & 0.331 & & 0.332 & 0.326 & 0.085 & 0.332 & 0.749 & 0.753 & 0.334 & 0.084 & 0.345 & 0.338 \\
\hline $\mathbf{Z n}$ & 0.338 & 0.338 & 0.756 & 0.499 & 0.342 & 0.743 & 0.751 & 0.326 & 0.083 & & 0.328 & 0.758 & 0.323 & 0.334 & 0.744 & 0.337 & 0.741 & 0.081 \\
\hline $\mathbf{R b}$ & 0.083 & 0.747 & 0.334 & 0.507 & 0.750 & 0.337 & 0.326 & 0.085 & 0.338 & 0.328 & & 0.338 & 0.751 & 0.749 & 0.340 & 0.086 & 0.332 & 0.323 \\
\hline Sr & 0.338 & 1.000 & 0.759 & 1.000 & 1.000 & 0.757 & 0.753 & 0.332 & 0.744 & 0.758 & 0.338 & & 1.000 & 1.000 & 0.754 & 0.330 & 0.084 & 0.753 \\
\hline $\mathbf{Y}$ & 0.751 & 0.753 & 1.000 & 1.000 & 0.752 & 1.000 & 1.000 & 0.749 & 0.336 & 0.323 & 0.751 & 1.000 & & 0.085 & 1.000 & 0.748 & 1.000 & 0.336 \\
\hline $\mathbf{Z r}$ & 0.749 & 0.750 & 1.000 & 1.000 & 0.747 & 1.000 & 1.000 & 0.753 & 0.335 & 0.334 & 0.749 & 1.000 & 0.085 & & 1.000 & 0.754 & 1.000 & 0.346 \\
\hline $\mathbf{N b}$ & 0.333 & 0.335 & 0.085 & 0.172 & 0.341 & 0.083 & 0.084 & 0.334 & 0.736 & 0.744 & 0.340 & 0.754 & 1.000 & 1.000 & & 0.325 & 0.752 & 0.753 \\
\hline $\mathbf{B a}$ & 0.086 & 0.747 & 0.338 & 0.509 & 0.750 & 0.336 & 0.330 & 0.084 & 0.325 & 0.337 & 0.086 & 0.330 & 0.748 & 0.754 & 0.325 & & 0.326 & 0.332 \\
\hline $\mathbf{P b}$ & 0.334 & 1.000 & 0.745 & 1.000 & 1.000 & 0.740 & 0.754 & 0.345 & 0.754 & 0.741 & 0.332 & 0.084 & 1.000 & 1.000 & 0.752 & 0.326 & & 0.749 \\
\hline Th & 0.336 & 0.331 & 0.747 & 0.486 & 0.336 & 0.752 & 0.751 & 0.338 & 0.081 & 0.081 & 0.323 & 0.753 & 0.336 & 0.346 & 0.753 & 0.332 & 0.749 & \\
\hline
\end{tabular}

Table 8. Correlations [ $\mathrm{p}$ (uncorr.)] for EDXRF data for samples from Endonyo Osunyai based on Kendall's Tau Monte Carlo simulations. 


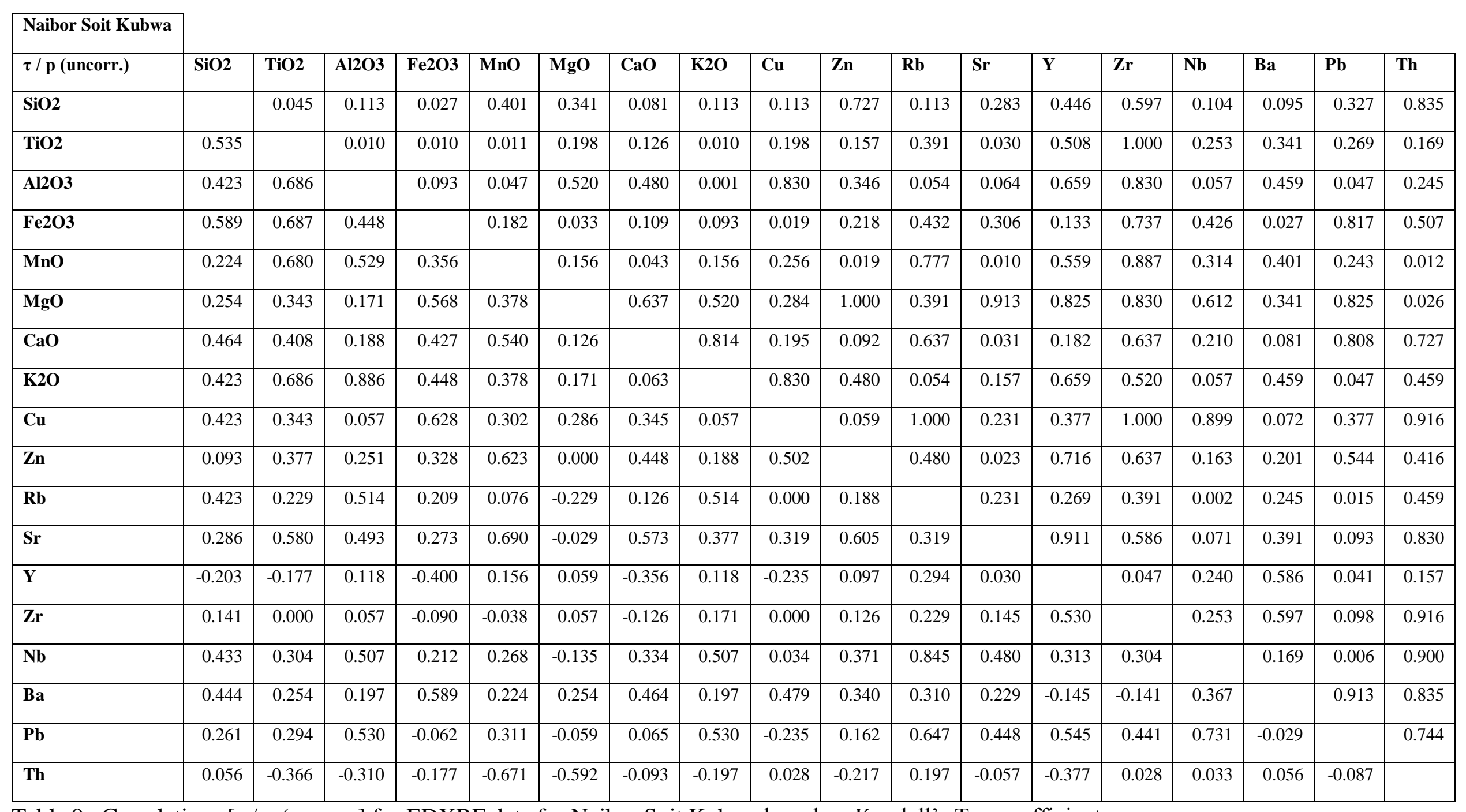

Table 9. Correlations [ $\tau / \mathrm{p}$ (uncorr.] for EDXRF data for Naibor Soit Kubwa based on Kendall's Tau coefficient. 


\begin{tabular}{|c|c|c|c|c|c|c|c|c|c|c|c|c|c|c|c|c|c|c|}
\hline Naibor Soit Kubwa & & & & & & & & & & & & & & & & & & \\
\hline p Permutations & $\mathrm{SiO2}$ & TiO2 & Al2O3 & $\mathrm{Fe} 2 \mathrm{O3}$ & MnO & MgO & $\mathrm{CaO}$ & K2O & $\mathbf{C u}$ & Zn & $\mathbf{R b}$ & $\mathrm{Sr}$ & $\mathbf{Y}$ & $\mathrm{Zr}$ & Nb & Ba & $\mathbf{P b}$ & Th \\
\hline$\overline{\mathrm{SiO2}}$ & & 0.055 & 0.152 & 0.040 & 0.538 & 0.411 & 0.130 & 0.149 & 0.148 & 0.835 & 0.143 & 0.352 & 0.533 & 0.688 & 0.168 & 0.120 & 0.418 & 0.919 \\
\hline TiO2 & 0.055 & & 0.012 & 0.013 & 0.020 & 0.252 & 0.154 & 0.013 & 0.255 & 0.229 & 0.472 & 0.030 & 0.602 & 1.000 & 0.332 & 0.408 & 0.339 & 0.217 \\
\hline $\mathrm{Al2O3}$ & 0.152 & 0.012 & & 0.137 & 0.084 & 0.601 & 0.581 & 0.000 & 0.916 & 0.451 & 0.068 & 0.087 & 0.756 & 0.912 & 0.093 & 0.533 & 0.065 & 0.300 \\
\hline Fe2O3 & 0.040 & 0.013 & 0.137 & & 0.291 & 0.051 & 0.165 & 0.133 & 0.024 & 0.297 & 0.518 & 0.352 & 0.186 & 0.825 & 0.535 & 0.041 & 0.860 & 0.602 \\
\hline $\mathrm{MnO}$ & 0.538 & 0.020 & 0.084 & 0.291 & & 0.237 & 0.099 & 0.238 & 0.364 & 0.049 & 0.839 & 0.015 & 0.704 & 0.967 & 0.378 & 0.545 & 0.367 & 0.025 \\
\hline MgO & 0.411 & 0.252 & 0.601 & 0.051 & 0.237 & & 0.735 & 0.601 & 0.357 & 1.000 & 0.473 & 0.995 & 0.910 & 0.914 & 0.717 & 0.406 & 0.913 & 0.031 \\
\hline $\mathrm{CaO}$ & 0.130 & 0.154 & 0.581 & 0.165 & 0.099 & 0.735 & & 0.904 & 0.244 & 0.166 & 0.739 & 0.051 & 0.259 & 0.734 & 0.321 & 0.130 & 0.883 & 0.836 \\
\hline K2O & 0.149 & 0.013 & 0.000 & 0.133 & 0.238 & 0.601 & 0.904 & & 0.918 & 0.578 & 0.071 & 0.206 & 0.756 & 0.613 & 0.091 & 0.543 & 0.067 & 0.539 \\
\hline $\mathbf{C u}$ & 0.148 & 0.255 & 0.916 & 0.024 & 0.364 & 0.357 & 0.244 & 0.918 & & 0.099 & 1.000 & 0.296 & 0.460 & 1.000 & 0.940 & 0.089 & 0.463 & 1.000 \\
\hline $\mathbf{Z n}$ & 0.835 & 0.229 & 0.451 & 0.297 & 0.049 & 1.000 & 0.166 & 0.578 & 0.099 & & 0.578 & 0.040 & 0.796 & 0.745 & 0.255 & 0.287 & 0.622 & 0.528 \\
\hline $\mathbf{R b}$ & 0.143 & 0.472 & 0.068 & 0.518 & 0.839 & 0.473 & 0.739 & 0.071 & 1.000 & 0.578 & & 0.292 & 0.341 & 0.470 & 0.001 & 0.305 & 0.021 & 0.539 \\
\hline $\mathbf{S r}$ & 0.352 & 0.030 & 0.087 & 0.352 & 0.015 & 0.995 & 0.051 & 0.206 & 0.296 & 0.040 & 0.292 & & 0.989 & 0.679 & 0.114 & 0.468 & 0.125 & 0.920 \\
\hline $\mathbf{Y}$ & 0.533 & 0.602 & 0.756 & 0.186 & 0.704 & 0.910 & 0.259 & 0.756 & 0.460 & 0.796 & 0.341 & 0.989 & & 0.065 & 0.346 & 0.680 & 0.057 & 0.207 \\
\hline $\mathbf{Z r}$ & 0.688 & 1.000 & 0.912 & 0.825 & 0.967 & 0.914 & 0.734 & 0.613 & 1.000 & 0.745 & 0.470 & 0.679 & 0.065 & & 0.318 & 0.680 & 0.113 & 1.000 \\
\hline $\mathbf{N b}$ & 0.168 & 0.332 & 0.093 & 0.535 & 0.378 & 0.717 & 0.321 & 0.091 & 0.940 & 0.255 & 0.001 & 0.114 & 0.346 & 0.318 & & 0.251 & 0.010 & 1.000 \\
\hline $\mathbf{B a}$ & 0.120 & 0.408 & 0.533 & 0.041 & 0.545 & 0.406 & 0.130 & 0.543 & 0.089 & 0.287 & 0.305 & 0.468 & 0.680 & 0.680 & 0.251 & & 1.000 & 0.918 \\
\hline $\mathbf{P b}$ & 0.418 & 0.339 & 0.065 & 0.860 & 0.367 & 0.913 & 0.883 & 0.067 & 0.463 & 0.622 & 0.021 & 0.125 & 0.057 & 0.113 & 0.010 & 1.000 & & 0.838 \\
\hline Th & 0.919 & 0.217 & 0.300 & 0.602 & 0.025 & 0.031 & 0.836 & 0.539 & 1.000 & 0.528 & 0.539 & 0.920 & 0.207 & 1.000 & 1.000 & 0.918 & 0.838 & \\
\hline
\end{tabular}

Table 10. Correlations [ p (uncorr.)] for EDXRF data for samples from Naibor Soit Kubwa based on Kendall's Tau Monte Carlo simulations. 


\begin{tabular}{|c|c|c|c|c|c|c|c|c|c|c|c|c|c|c|c|c|c|c|}
\hline Naibor Soit Ndogo & & & & & & & & & & & & & & & & & & \\
\hline$\tau / p$ (uncorr.) & $\mathrm{SiO2}$ & TiO2 & $\mathrm{Al2O3}$ & $\mathrm{Fe} 2 \mathrm{O3}$ & MnO & MgO & $\mathrm{CaO}$ & $\mathrm{K2O}$ & $\mathrm{Cu}$ & $\mathbf{Z n}$ & $\mathbf{R b}$ & $\mathrm{Sr}$ & $\mathbf{Y}$ & $\mathbf{Z r}$ & $\mathrm{Nb}$ & $\mathbf{B a}$ & $\mathbf{P b}$ & Th \\
\hline $\mathrm{SiO} 2$ & & 0.355 & 0.410 & 0.245 & 0.189 & 0.035 & 0.106 & 0.784 & 0.120 & 0.319 & 0.314 & 0.086 & 0.711 & 0.647 & 0.141 & 0.234 & 0.784 & 0.170 \\
\hline TiO2 & -0.230 & & 0.026 & 0.915 & 0.260 & 0.139 & 0.102 & 0.042 & 0.139 & 0.158 & 0.016 & 1.000 & 0.160 & 0.052 & 0.234 & 0.579 & 0.459 & 0.355 \\
\hline $\mathrm{Al} 203$ & -0.205 & 0.552 & & 0.526 & 0.266 & 0.055 & 0.086 & 0.000 & 0.170 & 0.017 & 0.001 & 0.334 & 0.355 & 0.314 & 0.659 & 0.234 & 0.784 & 0.170 \\
\hline $\mathrm{Fe} 2 \mathrm{O3}$ & 0.289 & 0.027 & 0.157 & & 0.243 & 0.526 & 0.484 & 0.342 & 0.833 & 0.249 & 1.000 & 0.137 & 0.019 & 0.833 & 0.610 & 0.751 & 0.398 & 0.398 \\
\hline MnO & -0.327 & -0.280 & -0.276 & -0.290 & & 0.613 & 0.911 & 0.086 & 0.020 & 0.078 & 0.266 & 0.001 & 0.220 & 0.129 & 0.051 & 0.189 & 0.129 & 0.613 \\
\hline MgO & -0.523 & 0.368 & 0.477 & -0.157 & 0.126 & & 0.001 & 0.170 & 0.784 & 0.425 & 0.082 & 0.238 & 0.579 & 0.410 & 0.659 & 0.120 & 0.522 & 0.647 \\
\hline $\mathrm{CaO}$ & 0.402 & -0.407 & -0.427 & 0.174 & -0.028 & -0.804 & & 0.189 & 0.762 & 0.508 & 0.086 & 0.286 & 0.413 & 0.363 & 1.000 & 0.363 & 0.762 & 0.919 \\
\hline K2O & -0.068 & 0.506 & 0.886 & 0.236 & -0.427 & 0.341 & -0.327 & & 0.055 & 0.009 & 0.001 & 0.108 & 0.267 & 0.234 & 0.556 & 0.410 & 0.647 & 0.082 \\
\hline $\mathrm{Cu}$ & 0.386 & 0.368 & 0.341 & 0.052 & -0.578 & -0.068 & 0.075 & 0.477 & & 0.231 & 0.120 & 0.042 & 0.711 & 0.120 & 0.027 & 0.314 & 0.784 & 0.067 \\
\hline $\mathbf{Z n}$ & -0.248 & 0.351 & 0.595 & 0.286 & -0.438 & 0.198 & -0.164 & 0.644 & 0.297 & & 0.028 & 0.079 & 0.920 & 0.690 & 0.630 & 0.765 & 0.046 & 0.690 \\
\hline $\mathbf{R b}$ & -0.250 & 0.598 & 0.795 & 0.000 & -0.276 & 0.432 & -0.427 & 0.795 & 0.386 & 0.545 & & 0.453 & 0.579 & 0.522 & 0.303 & 0.784 & 0.927 & 0.410 \\
\hline $\mathrm{Sr}$ & 0.426 & 0.000 & 0.240 & 0.369 & -0.796 & -0.293 & 0.265 & 0.400 & 0.506 & 0.436 & 0.187 & & 0.664 & 0.163 & 0.300 & 0.668 & 0.108 & 0.238 \\
\hline $\mathbf{Y}$ & 0.092 & 0.349 & 0.230 & 0.584 & -0.305 & 0.138 & -0.203 & 0.276 & 0.092 & 0.025 & 0.138 & 0.108 & & 0.042 & 0.655 & 0.853 & 0.711 & 0.711 \\
\hline $\mathrm{Zr}$ & 0.114 & 0.483 & 0.250 & 0.052 & -0.377 & 0.205 & -0.226 & 0.295 & 0.386 & 0.099 & 0.159 & 0.346 & 0.506 & & 0.883 & 0.927 & 0.927 & 0.120 \\
\hline $\mathbf{N b}$ & 0.366 & 0.296 & 0.110 & -0.127 & -0.485 & -0.110 & 0.000 & 0.146 & 0.548 & 0.120 & 0.256 & 0.257 & -0.111 & 0.037 & & 0.027 & 1.000 & 0.883 \\
\hline Ba & -0.295 & -0.138 & 0.295 & 0.079 & 0.327 & 0.386 & -0.226 & 0.205 & -0.250 & 0.074 & 0.068 & -0.107 & -0.046 & 0.023 & -0.548 & & 0.647 & 0.234 \\
\hline $\mathbf{P b}$ & -0.068 & -0.184 & 0.068 & 0.210 & -0.377 & -0.159 & 0.075 & 0.114 & 0.068 & 0.496 & 0.023 & 0.400 & -0.092 & -0.023 & 0.000 & 0.114 & & 0.647 \\
\hline Th & -0.341 & -0.230 & -0.341 & -0.210 & 0.126 & -0.114 & 0.025 & -0.432 & -0.455 & -0.099 & -0.205 & -0.293 & -0.092 & -0.386 & 0.037 & -0.295 & 0.114 & \\
\hline
\end{tabular}

Table 11. Correlations [ $\tau / \mathrm{p}$ (uncorr.] for EDXRF data for Naibor Soit Ndogo based on Kendall's Tau coefficient. 


\begin{tabular}{|c|c|c|c|c|c|c|c|c|c|c|c|c|c|c|c|c|c|c|}
\hline Naibor Soit Ndogo & & & & & & & & & & & & & & & & & & \\
\hline p Permutations & $\mathrm{SiO2}$ & $\mathrm{TiO2}$ & $\mathrm{Al2O3}$ & $\mathrm{Fe} 2 \mathrm{O3}$ & $\mathrm{MnO}$ & $\mathrm{MgO}$ & $\mathrm{CaO}$ & $\mathrm{K2O}$ & $\mathrm{Cu}$ & $\mathbf{Z n}$ & $\mathbf{R b}$ & $\mathrm{Sr}$ & $\mathbf{Y}$ & $\mathbf{Z r}$ & $\mathrm{Nb}$ & Ba & $\mathbf{P b}$ & Th \\
\hline $\mathrm{SiO2}$ & & 0.430 & 0.468 & 0.317 & 0.262 & 0.044 & 0.138 & 0.854 & 0.154 & 0.403 & 0.368 & 0.126 & 0.788 & 0.730 & 0.250 & 0.289 & 0.862 & 0.216 \\
\hline $\mathrm{TiO2}$ & 0.430 & & 0.036 & 0.974 & 0.320 & 0.175 & 0.151 & 0.059 & 0.184 & 0.209 & 0.020 & 1.000 & 0.204 & 0.058 & 0.405 & 0.662 & 0.534 & 0.418 \\
\hline Al2O3 & 0.468 & 0.036 & & 0.626 & 0.347 & 0.073 & 0.130 & 0.000 & 0.218 & 0.025 & 0.002 & 0.432 & 0.429 & 0.382 & 0.779 & 0.287 & 0.863 & 0.218 \\
\hline $\mathrm{Fe} 2 \mathrm{O3}$ & 0.317 & 0.974 & 0.626 & & 0.350 & 0.629 & 0.595 & 0.415 & 0.906 & 0.350 & 1.000 & 0.234 & 0.034 & 0.906 & 0.869 & 0.798 & 0.497 & 0.497 \\
\hline MnO & 0.262 & 0.320 & 0.347 & 0.350 & & 0.706 & 0.945 & 0.130 & 0.031 & 0.130 & 0.348 & 0.005 & 0.289 & 0.187 & 0.185 & 0.266 & 0.182 & 0.692 \\
\hline MgO & 0.044 & 0.175 & 0.073 & 0.629 & 0.706 & & 0.000 & 0.215 & 0.861 & 0.507 & 0.107 & 0.328 & 0.667 & 0.476 & 0.760 & 0.158 & 0.595 & 0.724 \\
\hline $\mathrm{CaO}$ & 0.138 & 0.151 & 0.130 & 0.595 & 0.945 & 0.000 & & 0.251 & 0.841 & 0.591 & 0.123 & 0.407 & 0.499 & 0.454 & 1.000 & 0.451 & 0.839 & 0.987 \\
\hline $\mathrm{K2O}$ & 0.854 & 0.059 & 0.000 & 0.415 & 0.130 & 0.215 & 0.251 & & 0.069 & 0.013 & 0.001 & 0.170 & 0.328 & 0.291 & 0.662 & 0.485 & 0.728 & 0.108 \\
\hline $\mathbf{C u}$ & 0.154 & 0.184 & 0.218 & 0.906 & 0.031 & 0.861 & 0.841 & 0.069 & & 0.305 & 0.147 & 0.065 & 0.781 & 0.146 & 0.055 & 0.378 & 0.863 & 0.073 \\
\hline $\mathrm{Zn}$ & 0.403 & 0.209 & 0.025 & 0.350 & 0.130 & 0.507 & 0.591 & 0.013 & 0.305 & & 0.043 & 0.140 & 0.979 & 0.771 & 0.754 & 0.799 & 0.067 & 0.781 \\
\hline $\mathbf{R b}$ & 0.368 & 0.020 & 0.002 & 1.000 & 0.348 & 0.107 & 0.123 & 0.001 & 0.147 & 0.043 & & 0.554 & 0.663 & 0.597 & 0.443 & 0.858 & 0.999 & 0.484 \\
\hline $\mathrm{Sr}$ & 0.126 & 1.000 & 0.432 & 0.234 & 0.005 & 0.328 & 0.407 & 0.170 & 0.065 & 0.140 & 0.554 & & 0.747 & 0.235 & 0.524 & 0.720 & 0.165 & 0.323 \\
\hline $\mathbf{Y}$ & 0.788 & 0.204 & 0.429 & 0.034 & 0.289 & 0.667 & 0.499 & 0.328 & 0.781 & 0.979 & 0.663 & 0.747 & & 0.050 & 0.759 & 0.924 & 0.786 & 0.789 \\
\hline$\underline{\mathbf{Z r}}$ & 0.730 & 0.058 & 0.382 & 0.906 & 0.187 & 0.476 & 0.454 & 0.291 & 0.146 & 0.771 & 0.597 & 0.235 & 0.050 & & 0.958 & 0.998 & 0.998 & 0.153 \\
\hline $\mathrm{Nb}$ & 0.250 & 0.405 & 0.779 & 0.869 & 0.185 & 0.760 & 1.000 & 0.662 & 0.055 & 0.754 & 0.443 & 0.524 & 0.759 & 0.958 & & 0.066 & 1.000 & 0.956 \\
\hline $\mathbf{B a}$ & 0.289 & 0.662 & 0.287 & 0.798 & 0.266 & 0.158 & 0.451 & 0.485 & 0.378 & 0.799 & 0.858 & 0.720 & 0.924 & 0.998 & 0.066 & & 0.726 & 0.286 \\
\hline $\mathbf{P b}$ & 0.862 & 0.534 & 0.863 & 0.497 & 0.182 & 0.595 & 0.839 & 0.728 & 0.863 & 0.067 & 0.999 & 0.165 & 0.786 & 0.998 & 1.000 & 0.726 & & 0.733 \\
\hline Th & 0.216 & 0.418 & 0.218 & 0.497 & 0.692 & 0.724 & 0.987 & 0.108 & 0.073 & 0.781 & 0.484 & 0.323 & 0.789 & 0.153 & 0.956 & 0.286 & 0.733 & \\
\hline
\end{tabular}

Table 12. Correlations [p (uncorr.)] for EDXRF data for samples from Naibor Soit Ndogo based on Kendall's Tau Monte Carlo simulations. 


\begin{tabular}{|c|c|c|c|c|c|c|c|c|c|c|c|c|c|c|c|c|c|c|}
\hline Naisiusiu & & & & & & & & & & & & & & & & & & \\
\hline$\tau / p$ (uncorr.) & $\mathrm{SiO2}$ & TiO2 & $\mathrm{Al2O3}$ & $\mathrm{Fe} 2 \mathrm{O3}$ & MnO & MgO & $\mathrm{CaO}$ & $\mathrm{K} 2 \mathrm{O}$ & $\mathbf{C u}$ & Zn & $\mathbf{R b}$ & $\mathrm{Sr}$ & $\mathbf{Y}$ & $\mathbf{Z r}$ & $\mathrm{Nb}$ & Ba & $\mathbf{P b}$ & Th \\
\hline $\mathrm{SiO2}$ & & 0.099 & 0.025 & 0.430 & 0.456 & 0.582 & 0.029 & 0.099 & 0.660 & 0.075 & 0.048 & 0.023 & 0.008 & 0.028 & 0.400 & 0.738 & 0.547 & 0.041 \\
\hline TiO2 & -0.332 & & 0.000 & 0.282 & 0.084 & 0.023 & 0.237 & 0.001 & 0.698 & 0.105 & 0.004 & 0.133 & 0.023 & 0.077 & 0.068 & 0.105 & 0.006 & 0.014 \\
\hline $\mathrm{Al2O3}$ & -0.451 & 0.796 & & 0.177 & 0.076 & 0.078 & 0.104 & 0.002 & 0.912 & 0.119 & 0.001 & 0.023 & 0.002 & 0.011 & 0.045 & 0.119 & 0.071 & 0.005 \\
\hline $\mathrm{Fe} 2 \mathrm{O3}$ & -0.158 & 0.216 & 0.271 & & 0.077 & 0.396 & 0.013 & 0.865 & 0.193 & 0.097 & 0.955 & 0.003 & 0.011 & 0.020 & 0.790 & 0.864 & 0.822 & 0.030 \\
\hline MnO & -0.150 & 0.347 & 0.357 & 0.355 & & 0.908 & 0.061 & 0.564 & 0.299 & 0.116 & 0.299 & 0.271 & 0.107 & 0.356 & 0.030 & 0.907 & 0.688 & 0.271 \\
\hline MgO & -0.111 & 0.456 & 0.354 & 0.171 & 0.023 & & 0.056 & 0.068 & 0.406 & 0.131 & 0.293 & 0.148 & 0.135 & 0.005 & 0.068 & 0.911 & 0.011 & 0.014 \\
\hline $\mathrm{CaO}$ & -0.438 & 0.237 & 0.326 & 0.497 & 0.377 & 0.384 & & 0.694 & 0.652 & 0.023 & 0.778 & 0.024 & 0.024 & 0.001 & 0.289 & 0.494 & 0.341 & 0.002 \\
\hline K2O & -0.332 & 0.689 & 0.619 & -0.034 & 0.116 & 0.367 & 0.079 & & 0.406 & 0.538 & 0.000 & 0.290 & 0.108 & 0.121 & 0.051 & 0.162 & 0.021 & 0.095 \\
\hline $\mathrm{Cu}$ & -0.088 & -0.078 & -0.022 & 0.261 & -0.208 & 0.167 & 0.090 & -0.167 & & 0.083 & 0.618 & 0.058 & 0.472 & 0.166 & 0.118 & 0.162 & 0.441 & 0.578 \\
\hline $\mathrm{Zn}$ & -0.358 & 0.326 & 0.313 & 0.333 & 0.316 & 0.303 & 0.457 & 0.124 & 0.348 & & 0.467 & 0.043 & 0.198 & 0.065 & 0.742 & 0.610 & 0.148 & 0.072 \\
\hline $\mathbf{R b}$ & -0.398 & 0.578 & 0.685 & 0.011 & 0.208 & 0.211 & 0.057 & 0.844 & -0.100 & 0.146 & & 0.106 & 0.053 & 0.150 & 0.068 & 0.083 & 0.078 & 0.182 \\
\hline $\mathbf{S r}$ & -0.456 & 0.302 & 0.456 & 0.594 & 0.221 & 0.291 & 0.455 & 0.212 & 0.380 & 0.407 & 0.324 & & 0.004 & 0.001 & 0.844 & 0.368 & 0.347 & 0.022 \\
\hline$Y$ & -0.530 & 0.456 & 0.619 & 0.512 & 0.324 & 0.300 & 0.452 & 0.322 & 0.144 & 0.258 & 0.389 & 0.581 & & 0.007 & 0.152 & 0.240 & 0.271 & 0.003 \\
\hline $\mathbf{Z r}$ & -0.442 & 0.356 & 0.508 & 0.466 & 0.185 & 0.567 & 0.689 & 0.311 & 0.278 & 0.371 & 0.289 & 0.682 & 0.544 & & 0.362 & 0.867 & 0.048 & 0.001 \\
\hline $\mathrm{Nb}$ & -0.169 & 0.366 & 0.403 & 0.054 & 0.436 & 0.366 & 0.213 & 0.392 & -0.314 & -0.066 & 0.366 & 0.039 & 0.288 & 0.183 & & 0.693 & 0.746 & 0.326 \\
\hline $\mathbf{B a}$ & -0.067 & 0.326 & 0.313 & -0.034 & 0.023 & 0.022 & -0.137 & 0.281 & 0.281 & 0.102 & 0.348 & 0.181 & 0.236 & 0.034 & -0.079 & & 0.045 & 0.736 \\
\hline $\mathbf{P b}$ & -0.121 & 0.552 & 0.363 & 0.045 & 0.081 & 0.508 & 0.191 & 0.464 & 0.155 & 0.291 & 0.354 & 0.189 & 0.221 & 0.398 & 0.065 & 0.402 & & 0.068 \\
\hline Th & -0.411 & 0.492 & 0.567 & 0.434 & 0.221 & 0.492 & 0.625 & 0.335 & 0.112 & 0.362 & 0.268 & 0.461 & 0.603 & 0.648 & 0.197 & 0.068 & 0.367 & \\
\hline
\end{tabular}

Table 13. Correlations [ $\tau$ / p (uncorr.] for EDXRF data for Naisiusiu based on Kendall's Tau coefficient. 


\begin{tabular}{|c|c|c|c|c|c|c|c|c|c|c|c|c|c|c|c|c|c|c|}
\hline Naisiusiu & & & & & & & & & & & & & & & & & & \\
\hline p Permutations & $\mathrm{SiO2}$ & $\mathrm{TiO} 2$ & $\mathrm{Al2O3}$ & $\mathrm{Fe} 2 \mathrm{O3}$ & MnO & MgO & $\mathrm{CaO}$ & $\mathrm{K} 2 \mathrm{O}$ & $\mathbf{C u}$ & $\mathbf{Z n}$ & $\mathbf{R b}$ & $\mathrm{Sr}$ & $\mathbf{Y}$ & $\mathbf{Z r}$ & $\mathbf{N b}$ & Ba & $\mathbf{P b}$ & Th \\
\hline $\mathrm{SiO} 2$ & & 0.115 & 0.025 & 0.480 & 0.514 & 0.626 & 0.035 & 0.118 & 0.712 & 0.088 & 0.052 & 0.025 & 0.008 & 0.028 & 0.491 & 0.785 & 0.590 & 0.046 \\
\hline $\mathrm{TiO2}$ & 0.115 & & 0.000 & 0.316 & 0.105 & 0.025 & 0.247 & 0.000 & 0.743 & 0.128 & 0.003 & 0.136 & 0.026 & 0.079 & 0.110 & 0.120 & 0.006 & 0.017 \\
\hline $\mathrm{Al2O3}$ & 0.025 & 0.000 & & 0.204 & 0.104 & 0.091 & 0.125 & 0.002 & 0.956 & 0.137 & 0.000 & 0.025 & 0.001 & 0.013 & 0.075 & 0.139 & 0.080 & 0.006 \\
\hline $\mathrm{Fe} 2 \mathrm{O3}$ & 0.480 & 0.316 & 0.204 & & 0.103 & 0.446 & 0.015 & 0.909 & 0.225 & 0.125 & 0.998 & 0.003 & 0.013 & 0.024 & 0.844 & 0.906 & 0.876 & 0.040 \\
\hline MnO & 0.514 & 0.105 & 0.104 & 0.103 & & 0.950 & 0.079 & 0.622 & 0.343 & 0.138 & 0.351 & 0.325 & 0.134 & 0.406 & 0.061 & 0.943 & 0.740 & 0.319 \\
\hline MgO & 0.626 & 0.025 & 0.091 & 0.446 & 0.950 & & 0.067 & 0.082 & 0.447 & 0.155 & 0.330 & 0.171 & 0.158 & 0.004 & 0.109 & 0.919 & 0.011 & 0.014 \\
\hline $\mathrm{CaO}$ & 0.035 & 0.247 & 0.125 & 0.015 & 0.079 & 0.067 & & 0.707 & 0.703 & 0.026 & 0.784 & 0.026 & 0.027 & 0.000 & 0.369 & 0.540 & 0.383 & 0.002 \\
\hline $\mathrm{K} 2 \mathrm{O}$ & 0.118 & 0.000 & 0.002 & 0.909 & 0.622 & 0.082 & 0.707 & & 0.444 & 0.584 & 0.000 & 0.302 & 0.126 & 0.125 & 0.085 & 0.186 & 0.023 & 0.107 \\
\hline $\mathrm{Cu}$ & 0.712 & 0.743 & 0.956 & 0.225 & 0.343 & 0.447 & 0.703 & 0.444 & & 0.098 & 0.667 & 0.066 & 0.519 & 0.191 & 0.175 & 0.181 & 0.483 & 0.619 \\
\hline $\mathrm{Zn}$ & 0.088 & 0.128 & 0.137 & 0.125 & 0.138 & 0.155 & 0.026 & 0.584 & 0.098 & & 0.513 & 0.054 & 0.228 & 0.077 & 0.790 & 0.656 & 0.170 & 0.087 \\
\hline $\mathbf{R b}$ & 0.052 & 0.003 & 0.000 & 0.998 & 0.351 & 0.330 & 0.784 & 0.000 & 0.667 & 0.513 & & 0.109 & 0.060 & 0.153 & 0.107 & 0.106 & 0.087 & 0.212 \\
\hline $\mathrm{Sr}$ & 0.025 & 0.136 & 0.025 & 0.003 & 0.325 & 0.171 & 0.026 & 0.302 & 0.066 & 0.054 & 0.109 & & 0.004 & 0.001 & 0.893 & 0.414 & 0.386 & 0.027 \\
\hline$Y$ & 0.008 & 0.026 & 0.001 & 0.013 & 0.134 & 0.158 & 0.027 & 0.126 & 0.519 & 0.228 & 0.060 & 0.004 & & 0.007 & 0.215 & 0.273 & 0.300 & 0.002 \\
\hline $\mathrm{Zr}$ & 0.028 & 0.079 & 0.013 & 0.024 & 0.406 & 0.004 & 0.000 & 0.125 & 0.191 & 0.077 & 0.153 & 0.001 & 0.007 & & 0.447 & 0.912 & 0.050 & 0.001 \\
\hline $\mathrm{Nb}$ & 0.491 & 0.110 & 0.075 & 0.844 & 0.061 & 0.109 & 0.369 & 0.085 & 0.175 & 0.790 & 0.107 & 0.893 & 0.215 & 0.447 & & 0.759 & 0.814 & 0.405 \\
\hline $\mathbf{B a}$ & 0.785 & 0.120 & 0.139 & 0.906 & 0.943 & 0.919 & 0.540 & 0.186 & 0.181 & 0.656 & 0.106 & 0.414 & 0.273 & 0.912 & 0.759 & & 0.052 & 0.786 \\
\hline $\mathbf{P b}$ & 0.590 & 0.006 & 0.080 & 0.876 & 0.740 & 0.011 & 0.383 & 0.023 & 0.483 & 0.170 & 0.087 & 0.386 & 0.300 & 0.050 & 0.814 & 0.052 & & 0.085 \\
\hline Th & 0.046 & 0.017 & 0.006 & 0.040 & 0.319 & 0.014 & 0.002 & 0.107 & 0.619 & 0.087 & 0.212 & 0.027 & 0.002 & 0.001 & 0.405 & 0.786 & 0.085 & \\
\hline
\end{tabular}

Table 14. Correlations [p (uncorr.)] for EDXRF data for samples from Naisiusiu based on Kendall's Tau Monte Carlo simulations. 


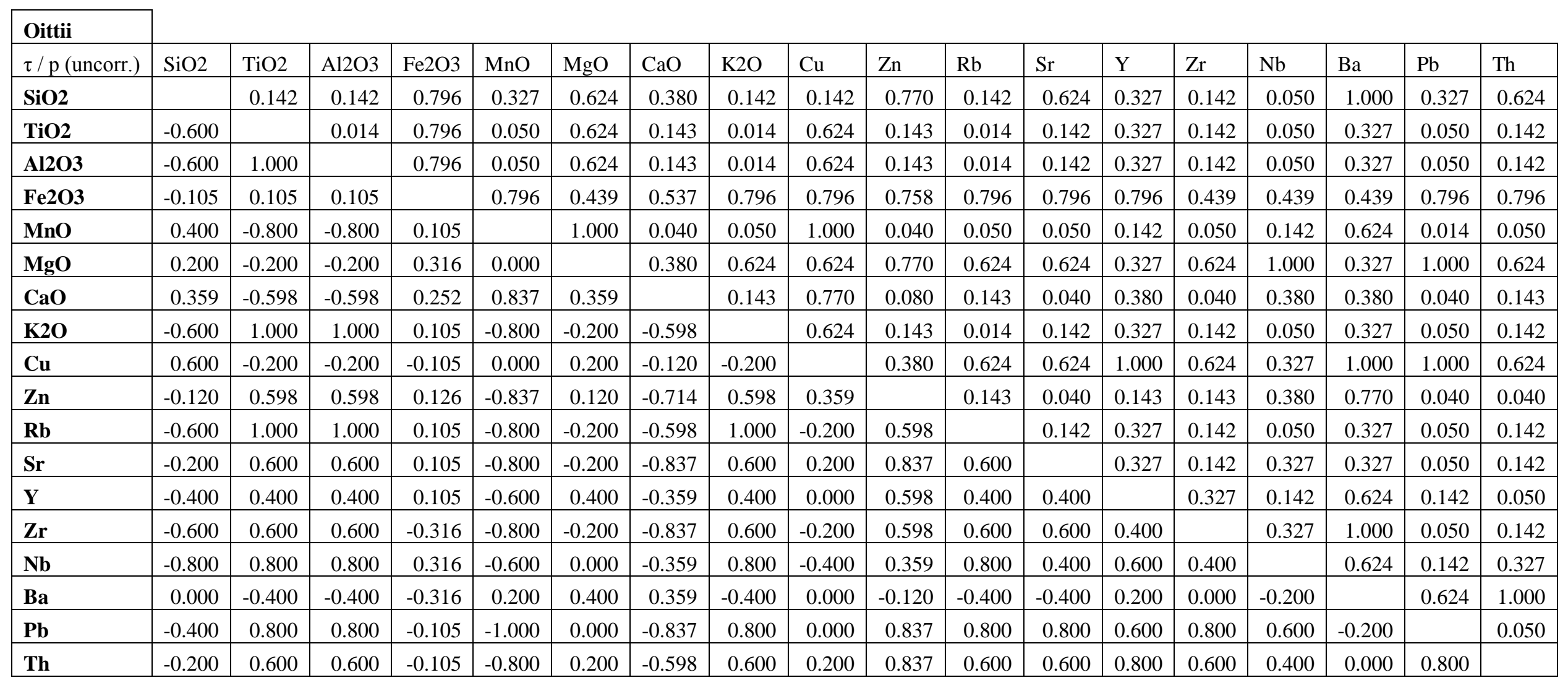

Table 15. Correlations [ $\tau$ / p (uncorr.] for EDXRF data for Oittii based on Kendall's Tau coefficient. 


\begin{tabular}{|c|c|c|c|c|c|c|c|c|c|c|c|c|c|c|c|c|c|c|}
\hline Oittii & & & & & & & & & & & & & & & & & & \\
\hline$P$ permutations & $\mathrm{SiO} 2$ & TiO2 & $\mathrm{Al} 203$ & $\mathrm{Fe} 2 \mathrm{O3}$ & $\mathrm{MnO}$ & MgO & $\mathrm{CaO}$ & K2O & $\mathbf{C u}$ & Zn & $\mathbf{R b}$ & $\mathrm{Sr}$ & $\mathbf{Y}$ & $\mathbf{Z r}$ & $\mathbf{N b}$ & $\mathbf{B a}$ & $\mathbf{P b}$ & Th \\
\hline $\mathrm{SiO} 2$ & & 0.232 & 0.240 & 1.000 & 0.490 & 0.823 & 0.613 & 0.231 & 0.236 & 1.000 & 0.231 & 0.821 & 0.488 & 0.234 & 0.084 & 1.000 & 0.484 & 0.821 \\
\hline TiO2 & 0.232 & & 0.018 & 1.000 & 0.085 & 0.816 & 0.304 & 0.018 & 0.819 & 0.299 & 0.018 & 0.228 & 0.488 & 0.243 & 0.084 & 0.489 & 0.082 & 0.238 \\
\hline $\mathrm{Al2O3}$ & 0.240 & 0.018 & & 1.000 & 0.088 & 0.819 & 0.304 & 0.016 & 0.817 & 0.301 & 0.017 & 0.231 & 0.477 & 0.234 & 0.079 & 0.482 & 0.090 & 0.233 \\
\hline $\mathrm{Fe} 2 \mathrm{O3}$ & 1.000 & 1.000 & 1.000 & & 1.000 & 0.631 & 0.749 & 1.000 & 1.000 & 0.903 & 1.000 & 1.000 & 1.000 & 0.632 & 0.634 & 0.635 & 1.000 & 1.000 \\
\hline MnO & 0.490 & 0.085 & 0.088 & 1.000 & & 1.000 & 0.104 & 0.088 & 1.000 & 0.092 & 0.082 & 0.083 & 0.231 & 0.086 & 0.232 & 0.814 & 0.017 & 0.083 \\
\hline MgO & 0.823 & 0.816 & 0.819 & 0.631 & 1.000 & & 0.594 & 0.812 & 0.825 & 1.000 & 0.819 & 0.820 & 0.493 & 0.821 & 1.000 & 0.492 & 1.000 & 0.815 \\
\hline $\mathrm{CaO}$ & 0.613 & 0.304 & 0.304 & 0.749 & 0.104 & 0.594 & & 0.301 & 1.000 & 0.291 & 0.289 & 0.099 & 0.600 & 0.104 & 0.594 & 0.603 & 0.098 & 0.309 \\
\hline $\mathrm{K} 2 \mathrm{O}$ & 0.231 & 0.018 & 0.016 & 1.000 & 0.088 & 0.812 & 0.301 & & 0.818 & 0.296 & 0.014 & 0.240 & 0.479 & 0.232 & 0.085 & 0.480 & 0.081 & 0.225 \\
\hline $\mathrm{Cu}$ & 0.236 & 0.819 & 0.817 & 1.000 & 1.000 & 0.825 & 1.000 & 0.818 & & 0.598 & 0.827 & 0.816 & 1.000 & 0.812 & 0.478 & 1.000 & 1.000 & 0.818 \\
\hline Zn & 1.000 & 0.299 & 0.301 & 0.903 & 0.092 & 1.000 & 0.291 & 0.296 & 0.598 & & 0.295 & 0.096 & 0.298 & 0.301 & 0.599 & 1.000 & 0.104 & 0.097 \\
\hline $\mathbf{R b}$ & 0.231 & 0.018 & 0.017 & 1.000 & 0.082 & 0.819 & 0.289 & 0.014 & 0.827 & 0.295 & & 0.229 & 0.487 & 0.237 & 0.093 & 0.492 & 0.082 & 0.244 \\
\hline $\mathrm{Sr}$ & 0.821 & 0.228 & 0.231 & 1.000 & 0.083 & 0.820 & 0.099 & 0.240 & 0.816 & 0.096 & 0.229 & & 0.480 & 0.242 & 0.489 & 0.476 & 0.080 & 0.234 \\
\hline $\mathbf{Y}$ & 0.488 & 0.488 & 0.477 & 1.000 & 0.231 & 0.493 & 0.600 & 0.479 & 1.000 & 0.298 & 0.487 & 0.480 & & 0.481 & 0.232 & 0.814 & 0.234 & 0.081 \\
\hline $\mathbf{Z r}$ & 0.234 & 0.243 & 0.234 & 0.632 & 0.086 & 0.821 & 0.104 & 0.232 & 0.812 & 0.301 & 0.237 & 0.242 & 0.481 & & 0.484 & 1.000 & 0.085 & 0.232 \\
\hline $\mathrm{Nb}$ & 0.084 & 0.084 & 0.079 & 0.634 & 0.232 & 1.000 & 0.594 & 0.085 & 0.478 & 0.599 & 0.093 & 0.489 & 0.232 & 0.484 & & 0.815 & 0.230 & 0.479 \\
\hline Ba & 1.000 & 0.489 & 0.482 & 0.635 & 0.814 & 0.492 & 0.603 & 0.480 & 1.000 & 1.000 & 0.492 & 0.476 & 0.814 & 1.000 & 0.815 & & 0.818 & 1.000 \\
\hline $\mathbf{P b}$ & 0.484 & 0.082 & 0.090 & 1.000 & 0.017 & 1.000 & 0.098 & 0.081 & 1.000 & 0.104 & 0.082 & 0.080 & 0.234 & 0.085 & 0.230 & 0.818 & & 0.085 \\
\hline Th & 0.821 & 0.238 & 0.233 & 1.000 & 0.083 & 0.815 & 0.309 & 0.225 & 0.818 & 0.097 & 0.244 & 0.234 & 0.081 & 0.232 & 0.479 & 1.000 & 0.085 & \\
\hline
\end{tabular}

Table 16. Correlations [p (uncorr.)] for EDXRF data for samples from Oittii based on Kendall's Tau Monte Carlo simulations.. 


\begin{tabular}{|c|c|c|c|c|c|c|}
\hline & $\begin{array}{c}\text { Endonyo } \\
\text { Osunyai }\end{array}$ & Naibor Soit Ndogo & $\begin{array}{c}\text { Naibor Soit } \\
\text { Kubwa }\end{array}$ & Naisiusiu & Oittii & Total \\
\hline $\begin{array}{c}\text { Endonyo } \\
\text { Osunyai }\end{array}$ & 4 & 0 & 0 & 0 & 0 & 4 \\
\hline Naibor Soit Ndogo & 0 & 13 & 0 & 1 & 0 & 14 \\
\hline Naibor Soit Kubwa & 0 & 0 & 9 & 0 & 0 & 9 \\
\hline Naisiusiu & 0 & 0 & 0 & 10 & 0 & 10 \\
\hline Oittii & 0 & 0 & 0 & 0 & 5 & 5 \\
\hline Total & 4 & 13 & 9 & 11 & 5 & 42 \\
\hline \% correctly classified & \multicolumn{5}{l}{$97.62 \%$} & \\
\hline
\end{tabular}

Table 17. Confusion matrix of DFA by outcrop classification.

\begin{tabular}{|c|c|c|c|c|c|c|}
\hline & $\begin{array}{c}\text { Endonyo } \\
\text { Osunyai }\end{array}$ & Naibor Soit Ndogo & $\begin{array}{c}\text { Naibor Soit } \\
\text { Kubwa }\end{array}$ & Naisiusiu & Oittii & Total \\
\hline $\begin{array}{c}\text { Endonyo } \\
\text { Osunyai }\end{array}$ & 0 & 0 & 2 & 0 & 2 & 4 \\
\hline Naibor Soit Ndogo & 0 & 11 & 0 & 3 & 0 & 14 \\
\hline Naibor Soit Kubwa & 0 & 0 & 7 & 2 & 0 & 9 \\
\hline Naisiusiu & 0 & 1 & 0 & 9 & 0 & 10 \\
\hline Oittii & 2 & 0 & 0 & 0 & 3 & 5 \\
\hline \multicolumn{2}{|l|}{ Total } & 2 & 9 & 14 & 5 & 42 \\
\hline \multicolumn{7}{|l|}{ \% correctly classified (Jackknife) }
\end{tabular}

Table 18. Confusion matrix of DFA by outcrop classification using Jackknife method.

\begin{tabular}{|c|c|c|c|c|c|c|c|c|c|c|}
\cline { 2 - 12 } \multicolumn{1}{c|}{} & G1 & GR1 & GR2 & GR5 & R3 & R5 & W2 & W3 & W4 & Total \\
\hline G1 & 1 & 0 & 0 & 0 & 0 & 0 & 0 & 0 & 0 & 1 \\
\hline GR1 & 0 & 4 & 0 & 0 & 1 & 0 & 0 & 0 & 0 & 5 \\
\hline GR2 & 0 & 1 & 6 & 0 & 0 & 0 & 0 & 0 & 0 & 7 \\
\hline GR5 & 0 & 0 & 0 & 1 & 0 & 0 & 0 & 0 & 0 & 1 \\
\hline R3 & 0 & 0 & 0 & 0 & 4 & 0 & 1 & 0 & 0 & 5 \\
\hline R5 & 0 & 0 & 0 & 0 & 0 & 2 & 0 & 0 & 0 & 2 \\
\hline W2 & 0 & 0 & 0 & 0 & 1 & 0 & 4 & 0 & 0 & 5 \\
\hline W3 & 1 & 0 & 0 & 0 & 0 & 0 & 1 & 11 & 0 & 13 \\
\hline W4 & 0 & 0 & 0 & 0 & 0 & 0 & 0 & 0 & 3 & 3 \\
\hline Total & 2 & 5 & 6 & 1 & 6 & 2 & 6 & 11 & 3 & 42 \\
\hline
\end{tabular}

Table 13. Confusion matrix of DFA by RMG classification.

\begin{tabular}{|l|l|l|l|l|l|l|l|l|l|l|}
\hline & G1 & GR1 & GR2 & GR5 & R3 & R5 & W2 & W3 & W4 & Total \\
\hline
\end{tabular}




\begin{tabular}{|c|c|c|c|c|c|c|c|c|c|c|}
\hline G1 & 0 & 0 & 0 & 0 & 0 & 0 & 1 & 0 & 0 & 1 \\
\hline GR1 & 0 & 3 & 0 & 0 & 1 & 0 & 1 & 0 & 0 & 5 \\
\hline GR2 & 0 & 1 & 3 & 3 & 0 & 0 & 0 & 0 & 0 & 7 \\
\hline GR5 & 0 & 1 & 0 & 0 & 0 & 0 & 0 & 0 & 0 & 1 \\
\hline R3 & 0 & 1 & 0 & 1 & 0 & 0 & 2 & 1 & 0 & 5 \\
\hline R5 & 0 & 0 & 0 & 0 & 0 & 2 & 0 & 0 & 0 & 2 \\
\hline W2 & 1 & 1 & 0 & 0 & 1 & 0 & 0 & 2 & 0 & 5 \\
\hline W3 & 1 & 1 & 0 & 0 & 0 & 0 & 2 & 8 & 1 & 13 \\
\hline W4 & 1 & 0 & 0 & 0 & 0 & 0 & 0 & 1 & 1 & 3 \\
\hline \multicolumn{2}{|l|}{ Total } & 8 & 3 & 4 & 2 & 2 & 6 & 12 & 2 & 42 \\
\hline
\end{tabular}

Table 14. Confusion matrix of DFA by RMG classification using Jackknife method. 